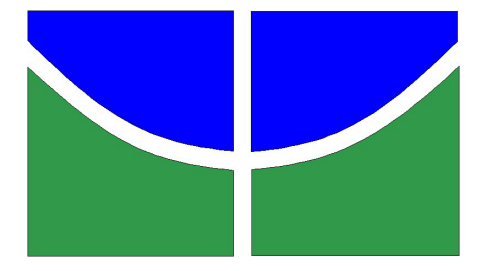

UNIVERSIDADE DE BRASÍLIA

FACULDADE DE COMUNICAÇÃO

PROGRAMA DE PÓS-GRADUAÇÃO

A implementação da Lei de Acesso à Informação nos Institutos

Federais de Educação, Ciência e Tecnologia

Wákila Nieble Rodrigues de Mesquita

Brasília

2015 


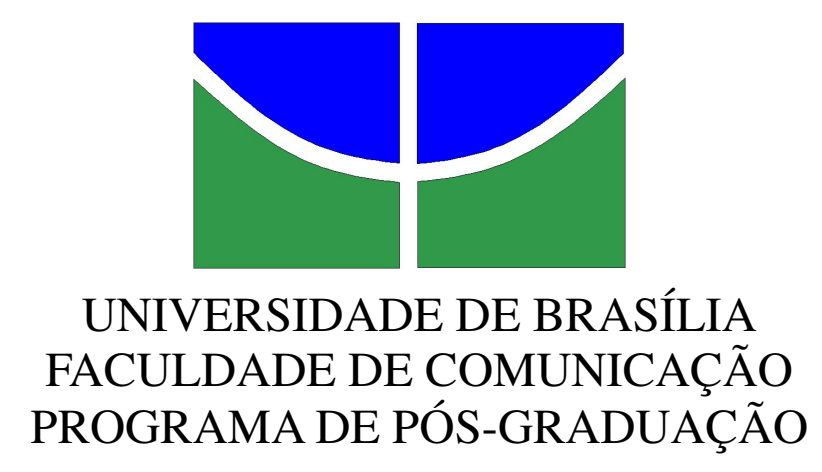

Wákila Nieble Rodrigues de Mesquita

\title{
A implementação da Lei de Acesso à Informação nos Institutos Federais de Educação, Ciência e Tecnologia
}

\author{
Dissertação apresentada ao \\ Programa de Pós-graduação em \\ Comunicação da Universidade de \\ Brasília, linha de Políticas de \\ Comunicação e Cultura, como \\ requisito parcial para a obtenção do \\ título de mestre. \\ Orientador: Prof. Dr. Carlos \\ Eduardo Esch
}




\section{Wákila Nieble Rodrigues de Mesquita}

A implementação da Lei de Acesso à Informação nos Institutos Federais de Educação, Ciência e Tecnologia.

Dissertação apresentada ao
Programa de Pós-graduação em
Comunicação da Universidade de
Brasília, linha de Políticas de
Comunicação e Cultura, como
requisito parcial para a obtenção do
título de mestre.
Orientador: Prof. Dr. Carlos
Eduardo Esch

Aprovado em 03 de agosto de 2015 pela seguinte Banca Examinadora:

Prof. Dr. Carlos Eduardo Esch - Presidente

Faculdade de Comunicação, Universidade de Brasília (UnB).

Prof. ${ }^{\text {a }}$ Dra. Elen Geraldes - membro

Faculdade de Comunicação, Universidade de Brasília (UnB).

Prof. ${ }^{a}$ Dra. - Georgete Medleg - membro

Faculdade de Ciência da Informação, Universidade de Brasília (UnB).

Prof. ${ }^{a}$ Dra ${ }^{\mathrm{a}}$ Nélia Del Bianco - Suplente

Faculdade de Comunicação, Universidade de Brasília (UnB). 


\section{AGRADECIMENTOS}

Agradeço a meu orientador, Prof. Dr. Carlos Eduardo Esch, pela paciência que demonstrou nesses dois anos e meio de trabalho conjunto. A ideia de realizar uma pesquisa, de cursar o mestrado, de sonhar na direção de fazer ciência é um trabalho um tanto pesado para quem herdou uma educação básica do sistema público. O professor Carlos Eduardo conseguiu, na maior parte do tempo, fazer com que eu me mantivesse calmo, sem desespero frente aos obstáculos que, agora, parecem menos complexos do que se mostraram durante a realização da pesquisa.

Devo agradecer aos colegas da Rede Federal de Educação, Ciência e Tecnologia que me atenderam e concederam as entrevistas necessárias para a realização deste trabalho. $\mathrm{O}$ fato de se dispuserem a falar pode parecer algo corriqueiro, porém, não é. A prova de que não se trata de algo encarado com naturalidade é que houve muitas recusas.

Meu agradecimento também aos professores do Programa de Pós-graduação da FAC-UnB. O tempo de convivência aqui me permitiu ir além do conhecimento técnico, contribuiu para o crescimento pessoal.

Os colegas com os quais cursei as disciplinas, muito me auxiliaram com os debates durante as aulas. A eles, meu agradecimento. 


\section{RESUMO}

Esta dissertação aborda a implementação da Lei de Acesso à Informação (Lei 12.527/2011), ou simplesmente LAI, na Rede Federal de Educação, Ciência e Tecnologia composta pelos Institutos Federais de Educação, Ciência e Tecnologia (IF's), Centros Federais de Educação Tecnológica (Cefet's), Universidade Federal Tecnológica e Colégio Pedro II. Assim, verificou-se como está ocorrendo a relação da LAI com a comunicação nessas instituições educacionais. Para tanto, foi realizado um levantamento, no primeiro semestre de 2013, nos sites dessas instituições, buscando compreender como a lei estava sendo aplicada nesses espaços virtuais. Após análise de conteúdo deste material dos sites, foram realizadas entrevistas com profissionais, servidores públicos que atuam com os setores de aplicação da LAI e com a comunicação nas instituições dessa Rede Federal de Educação, Ciência e Tecnologia. As entrevistas mostraram como a nova legislação está sendo posta em prática, tanto pelos operadores da LAI quanto pelos operadores da comunicação. A metodologia central utilizada aqui foi a Análise de Conteúdo, primeiro dos sites, depois, das entrevistas. $\mathrm{O}$ conceito teórico que embasou a construção da dissertação foi a Comunicação Pública. Observou-se, ao concluir a pesquisa, que os setores responsáveis por operacionalizar a LAI e os responsáveis por operacionalizar a comunicação não se relacionam institucionalmente.

Palavras-chave: Comunicação; LAI; Lei de Acesso à Informação; Transparência Ativa; Institutos Federais; 


\begin{abstract}
This dissertation discusses the implementation of the Access to Information Act (Law 12.527/2011), or simply "LAI", in the Federal Network of Education, Science and Technology consists of the Federal Institutes of Education, Science and Technology (IF's), Federal Centers of Technological Education (Cefet's), Federal Technological University and College Pedro II. Thus, it was found if it's occurring the "LAI's" relation with the communication in these educational institutions. Thus, a survey was conducted in the first half of 2013, on the websites of these institutions, trying to understand how the law was being applied in these virtual spaces. After content analysis of this material sites, interviews were conducted with professionals, public servants who work with the application sectors of "LAI" and with communication in institutions of this Federal Network for Education, Science and Technology. Interviews showed how the new legislation is being implemented by both the "LAI" operators and by communication operators. The central methodology used here was the Content Analysis, first of sites, then the interviews. The theoretical concept based the construction of the dissertation was the Public Communication. It was observed after completing the survey, that the sectors responsible for operating the communication do not relate institutionally.
\end{abstract}

Keywords: Communication; "LAI”; Access to Information Act; Active transparency; Federal Institutes; 


\section{LISTA DE QUADROS}

Quadro 1 - Legislação e declarações internacionais sobre o direito à informação. 16

Quadro 2 - Lista dos países que já contam com uma legislação de acesso à informação

Quadro 3 - Resumo do ambiente normativo brasileiro antes da publicação da Lei $12.527 / 2011$ .26 


\section{LISTA DE TABELAS}

Tabela $1 \quad-$ Motivos de negativas de resposta no

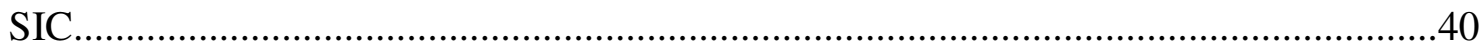

Tabela 2 - Dados dos Estados que mais fazem pedidos de informação no

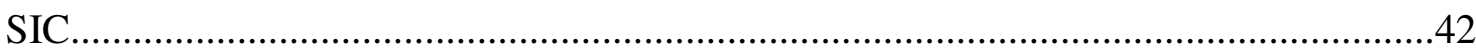

Tabela 3 - Lista com notas aos IF's conforme atendimento aos critérios da

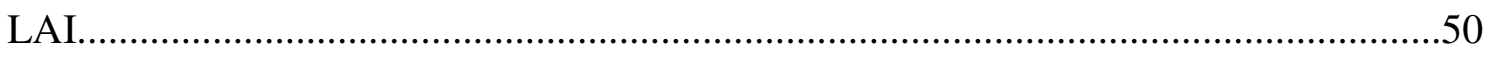

Tabela 4 - Onde se pratica a Comunicação Pública de acordo com a definição de CP adotada neste trabalho e orientada pela visão de

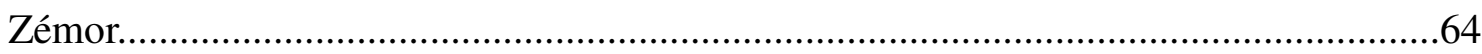

Tabela 5 - Tipos de comunicação de acordo com

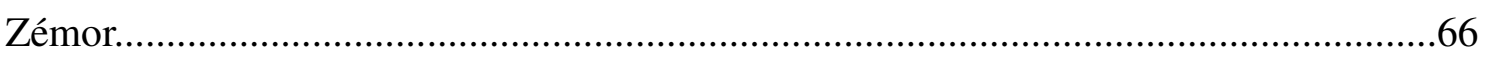




\section{LISTA DE ABREVIATURAS}

Andi = Agência de Notícias dos Direitos da Infância;

Cefet $=$ Centro Federal de Educação Tecnológica;

Cefet-MG = Centro Federal de Educação Tecnológica de Minas Gerais;

Cefet-RJ = Centro Federal de Educação Tecnológica do Rio de Janeiro;

CGU = Controladoria-Geral da União;

CP II = Colégio Pedro II;

EBTT = Educação Básica, Técnica e Tecnológica;

$\mathrm{IF}=$ Instituto Federal;

IFAC = Instituto Federal de Educação, Ciência e Tecnologia do Acre;

IFAL = Instituto Federal de Educação, Ciência e Tecnologia de Alagoas;

IFAM = Instituto Federal de Educação, Ciência e Tecnologia do Amazonas;

IFAP = Instituto Federal de Educação, Ciência e Tecnologia do Amapá;

IFB = Instituto Federal de Educação, Ciência e Tecnologia de Brasília;

IFBA = Instituto Federal de Educação, Ciência e Tecnologia da Bahia;

IF Baiano = Instituto Federal de Educação, Ciência e Tecnologia Baiano;

IFC = Instituto Federal de Educação, Ciência e Tecnologia Catarinense;

IFCE = Instituto Federal de Educação, Ciência e Tecnologia do Ceará;

IFES = Instituto Federal de Educação, Ciência e Tecnologia do Espírito Santo;

IF Farroupilha = Instituto Federal de Educação, Ciência e Tecnologia Farroupilha;

IFF = Instituto Federal de Educação, Ciência e Tecnologia Fluminense;

IFGO = Instituto Federal de Educação, Ciência e Tecnologia de Goiás;

IF Goiano = Instituto Federal de Educação, Ciência e Tecnologia Goiano;

IFMA = Instituto Federal de Educação, Ciência e Tecnologia do Maranhão; 
IFMG = Instituto Federal de Educação, Ciência e Tecnologia de Minas Gerais;

IFMS = Instituto Federal de Educação, Ciência e Tecnologia do Mato Grosso do Sul;

IFMT = Instituto Federal de Educação, Ciência e Tecnologia do Mato Grosso;

IFNMG = Instituto Federal de Educação, Ciência e Tecnologia do Norte de Minas Gerais;

IFPR = Instituto Federal de Educação, Ciência e Tecnologia do Paraná;

IFPA = Instituto Federal de Educação, Ciência e Tecnologia do Pará;

IFPB = Instituto Federal de Educação, Ciência e Tecnologia da Paraíba;

IFPE = Instituto Federal de Educação, Ciência e Tecnologia de Pernambuco;

IFPI = Instituto Federal de Educação, Ciência e Tecnologia do Piauí;

IFRS = Instituto Federal de Educação, Ciência e Tecnologia do Rio Grande do Sul;

IFRJ = Instituto Federal de Educação, Ciência e Tecnologia do Rio de Janeiro;

IFRN = Instituto Federal de Educação, Ciência e Tecnologia do Rio Grande do Norte;

IFRO = Instituto Federal de Educação, Ciência e Tecnologia de Rondônia;

IFRR = Instituto Federal de Educação, Ciência e Tecnologia de Roraima;

IFS = Instituto Federal de Educação, Ciência e Tecnologia do Sergipe;

IFSC = Instituto Federal de Educação, Ciência e Tecnologia de Santa Catarina;

IF Sertão = Instituto Federal de Educação, Ciência e Tecnologia do Sertão Pernambucano;

IFSP = Instituto Federal de Educação, Ciência e Tecnologia de São Paulo;

IF Sudeste MG = Instituto Federal de Educação, Ciência e Tecnologia do Sudeste de Minas Gerais;

IF Sul = Instituto Federal de Educação, Ciência e Tecnologia Sul Rio Grandense;

IF Sul de Minas = Instituto Federal de Educação, Ciência e Tecnologia do Sul de Minas Gerais; 
IFTM = Instituto Federal de Educação, Ciência e Tecnologia do Triângulo Mineiro;

IFTO = Instituto Federal de Educação, Ciência e Tecnologia do Tocantins;

LAI = Lei de Acesso à Informação;

MEC = Ministério da Educação;

PIS = Programa de Integração Social;

Setec $=$ Secretaria de Educação Profissional e Tecnológica;

SIC = Sistema de Informações ao Cidadão;

UnB = Universidade de Brasília;

UTFPR = Universidade Tecnológica Federal do Paraná;

TCU = Tribunal de Contas da União. 


\section{Apresentação}

A questão principal tratada nesta pesquisa é: como está ocorrendo a implementação da Lei de Acesso à Informação nos Institutos Federais de Educação, Ciência e Tecnologia?

A pergunta acima é justificada pelas mudanças na regulamentação do acesso à informação no Brasil com a entrada em vigor da Lei 12.527 de 18 de novembro de 2011 ou Lei de Acesso à Informação (LAI), que interferiu fortemente nas políticas públicas de acesso à informação até então, fragilmente, constituídas no País.

O interesse por pesquisar esse tema do Acesso à Informação surgiu a partir da vivência de quem realiza a pesquisa, que se insere em um ambiente de aplicação da LAI: sou jornalista de carreira do serviço público, atuando no Instituto Federal de Educação, Ciência e Tecnologia de Brasília (IFB), onde fui responsável pela organização do conteúdo da transparência ativa no site dessa Instituição.

O interesse pela LAI é sucessor do meu interesse por democracia e por transparência. Atuei como jornalista de veículo de mídia por três anos, metade em um jornal impresso semanal e a outra metade em um portal de notícias. A dificuldade em conseguir informações públicas e posicionamento de autoridades estatais sempre foi um empecilho para o meu trabalho jornalístico.

Após os três anos de redação, optei por atuar no setor público em uma assessoria de comunicação. Nessa experiência, mais uma vez, vi a dificuldade de se conseguir informações e o quanto é árduo o trabalho de tentar convencer os gestores a autorizarem que uma informação pública seja retirada das gavetas e publicizada.

Às experiências como profissional se somaram as que vieram da militância social, como, por exemplo, nos movimentos pelos direitos humanos, estudantil, sindical e de luta por direitos da população LGBT (lésbicas, gays, bissexuais e transgêneros). Nesses espaços de militância, as dificuldades de acesso às informações públicas se apresentavam de formas variadas, desde negativas de uma universidade em disponibilizar atas de reuniões de colegiado, no caso do movimento estudantil, até a resistência de autoridades de segurança pública em permitir acesso a dados sobre violência que envolviam a população LGBT ou a praticada pelas polícias contra 
populações pobres.

Esta pesquisa e meu interesse pela transparência das coisas do Estado, portanto, têm muito da minha trajetória profissional e pessoal. Negar tal influência dificultaria a compreensão deste trabalho.

Esta dissertação se encontra dividida em seis capítulos. O primeiro contém o histórico das leis de acesso à informação no mundo, assim como a descrição do processo que levou à criação da lei brasileira.

No segundo capítulo, exponho os caminhos metodológicos trilhados na realização desta pesquisa. O método aplicado neste trabalho foi a Análise de Conteúdo que esteve presente em todos os momentos da construção da dissertação.

No terceiro capítulo, apresento o conceito teórico usado na compreensão do objeto, a Comunicação Pública, e busco entender a LAI a partir das reflexões teóricas produzidas, partindo dela.

No quarto capítulo está a análise dos dados resultantes das entrevistas realizadas com os operadores da LAI. Essas entrevistas são a parte principal da pesquisa, pois permitiram compreender como está ocorrendo a implantação das políticas de acesso à informação ouvindo justamente quem as coloca em prática, realizando o atendimento direto ao público.

Em seu quinto capítulo, a dissertação trata da análise dos dados que resultaram das entrevistas realizadas com os operadores da comunicação.

Seria possível verificar se a LAI está sendo cumprida, avaliando os sites dos IF's ou enviando perguntas e esperando as respostas para testar se a lei está sendo aplicada. Entretanto, eu quis, nesta dissertação, ir além e compreender como a política está sendo posta em prática, daí a necessidade de entrevistar os comunicadores que fazem a transparência ativa funcionar no dia a dia das instituições.

Por fim, exponho as devidas conclusões a que consegui chegar depois de relacionar as informações dadas por operadores da LAI e da comunicação com as normas da lei e com a Comunicação Pública. Pude avaliar como está a relação LAIComunicação; verificar como os comunicadores entendem a LAI; como os operadores da LAI veem a comunicação; e, de que forma a LAI está influenciando os funcionários das assessorias de comunicação dos Institutos Federais. 


\section{Sumário}

1. Acesso à Informação: o longo caminho de construção da transparência......................16

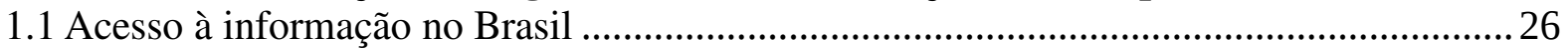

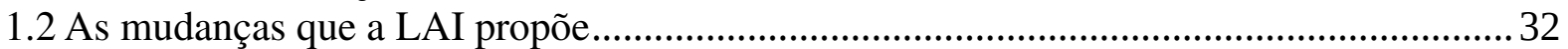

1.3 LAI no Brasil: primeiros momentos de implantação de uma política.................................36

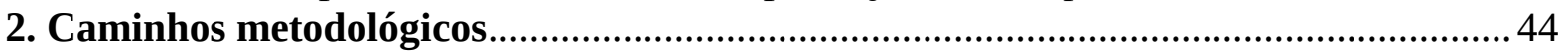

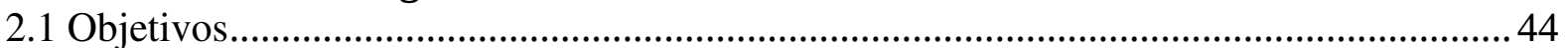

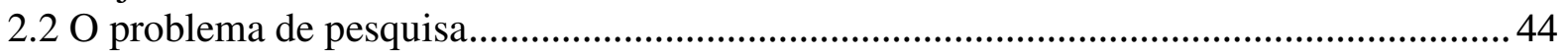

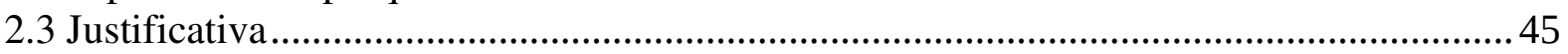

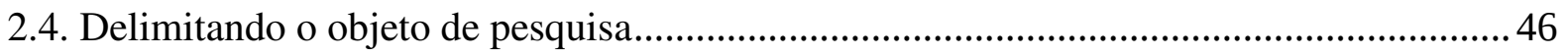

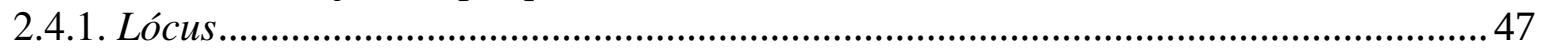

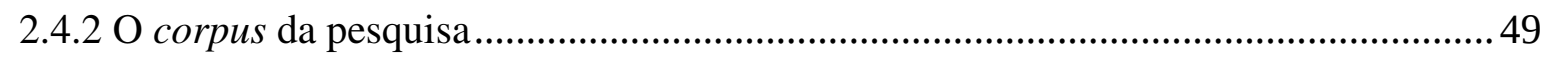

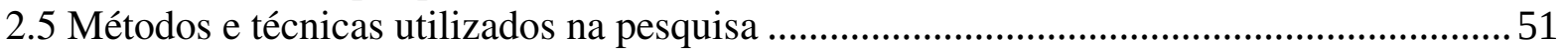

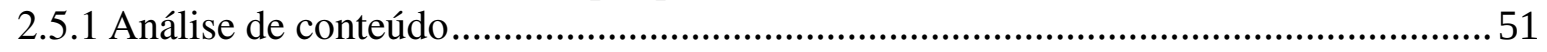

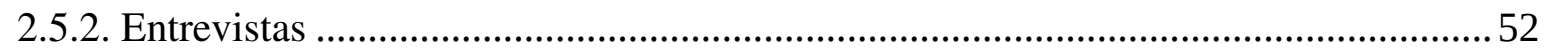

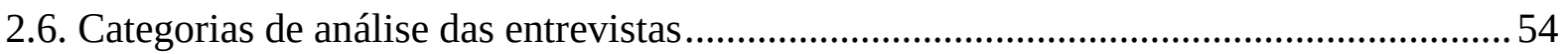

2.6.1. Categorias para analisar as entrevistas dos operadores da LAI................................54

2.6.2. Categorias para analisar as entrevistas dos operadores da comunicação: ..................54

3. Conceito teórico que dialoga com a pesquisa: Comunicação Pública ..........................56

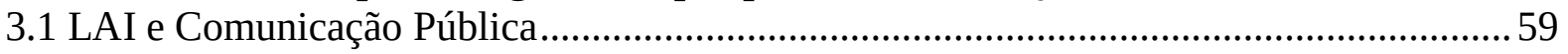

3.2 Comunicação Pública na visão de Pierre Zémor ..........................................................59

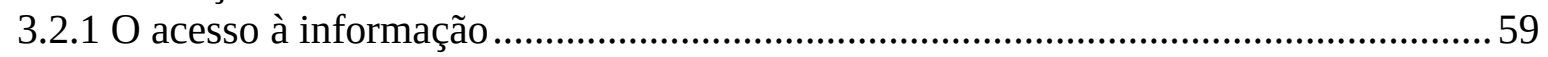

3.2.2 A relação entre cidadão e Estado na Comunicação Pública ........................................60

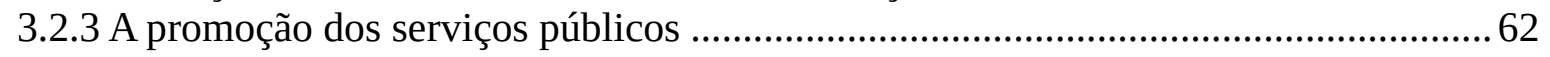

3.2.4. Que instituições devem usar a Comunicação Pública .................................................63

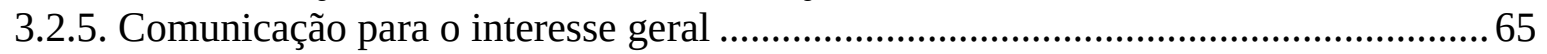

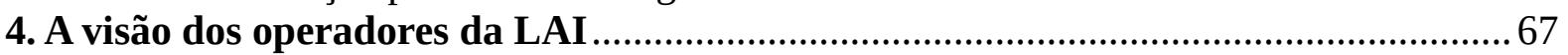

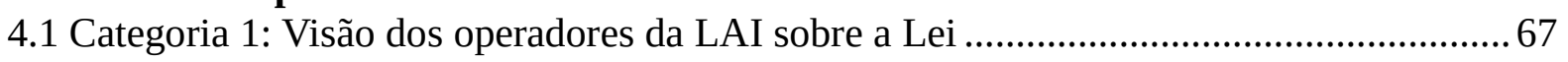

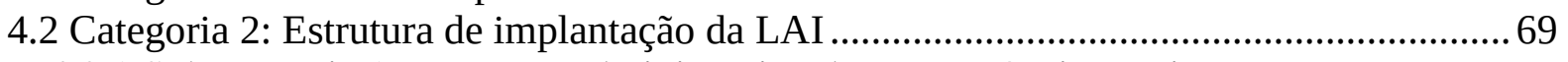

4.2.1 Subcategoria 1: Estrutura administrativa da transparência passiva...........................69

4.1.2 Subcategoria 2 - Estrutura administrativa da transparência ativa...............................74

4.2.3 Subcategoria 3 - Estrutura física dos setores da LAI ............................................... 80

4.3 Categoria 3: Visão dos operadores da LAI sobre a comunicação ....................................... 81

4.4 Categoria 4: Similaridades entre as funções da LAI e da Comunicação ............................. 84

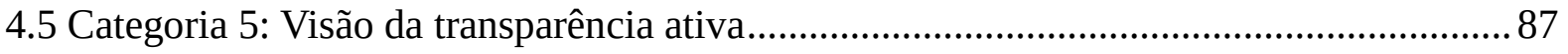

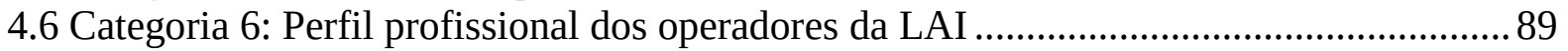

4.7 Categoria 7: Relações entre operador e usuário da informação .........................................91

5. Como os operadores da comunicação veem a LAI ..................................................... 95

5.1 Categoria 1: Nível de conhecimento da LAI ...................................................................96

5.2 Categoria 2: Proximidades entre a visão dos operadores da comunicação e as normas

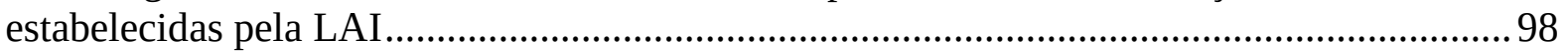

5.3 Categoria 3: Visão dos operadores da Comunicação sobre a LAI ................................... 105

5.4 Categoria 4: Avaliação da relação entre a LAI e a Comunicação ...................................... 107

5.5 Categoria 5: Mudanças influenciadas pela LAI ............................................................. 108

5.6 Categoria 6: Visão dos operadores da Comunicação sobre a transparência ativa ............ 112

5.7 Categoria 7: Estrutura física e de pessoal da comunicação .............................................. 114

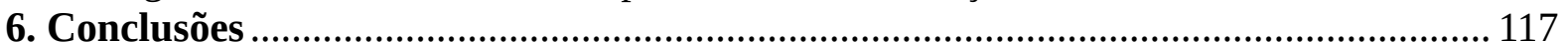


7. Referências

.125 


\section{Acesso à Informação: o longo caminho de construção da transparência}

De acordo com Mendel (2009, p. 8), em 14 de dezembro de 1946, a Organização das Nações Unidas (ONU) realizou sua primeira sessão e aprovou a Resolução 59 que afirma: “A liberdade de informação constitui um direito humano fundamental e a pedra de toque de todas as liberdades a que se dedica a ONU". Ainda, segundo o mesmo autor, esse foi o primeiro documento internacional a tratar do acesso à informação como um direito. Cerca de dois anos depois, em 10 de dezembro de 1948, foi aprovada pela Assembleia Geral da ONU a Declaração Universal dos Direitos Humanos, onde se encontra o Artigo XIX que determina:

Toda pessoa tem direito à liberdade de opinião e expressão; este direito inclui a liberdade de, sem interferência, ter opiniões e de procurar, receber e transmitir informações e ideias por quaisquer meios e independentemente de fronteiras (DECLARAÇÃO UNIVERSAL DOS DIREITOS HUMANOS, ARTIGO XIX).

Além da Declaração Universal dos Direitos Humanos, tratados e convenções regionais reconhecem o acesso à informação como um direito humano fundamental. Citam-se aqui três organizações que assim o fazem: Organização dos Estados Americanos (OEA), Conselho da Europa e União Africana (MENDEL, 2009). Além desses, outros documentos tratam da questão, conforme se pode observar no Quadro 1.

\begin{tabular}{|c|c|}
\hline \multicolumn{2}{|r|}{ Acordos internacionais que preveem o direito à informação } \\
\hline Ano - Acordo & Item que prevê o direito à informação \\
\hline $\begin{array}{c}1953 \text { - Convenção Europeia de } \\
\text { Direitos Humanos }\end{array}$ & $\begin{array}{l}\text { Artigo } 10 \text { - Liberdade de expressão: Qualquer pessoa tem direito à liberdade } \\
\text { de expressão. Este direito compreende a liberdade de opinião e a liberdade de } \\
\text { receber ou de transmitir informações ou ideias sem que possa haver } \\
\text { ingerência de quaisquer autoridades públicas e sem considerações de } \\
\text { fronteiras. O presente artigo não impede que os Estados submetam as } \\
\text { empresas de radiodifusão, de cinematografia ou de televisão a um regime de } \\
\text { autorização prévia. }\end{array}$ \\
\hline $\begin{array}{c}1966 \text { - Pacto Internacional } \\
\text { sobre Direitos Civis e Políticos }\end{array}$ & $\begin{array}{l}\text { Artigo } 19 \text { - Toda pessoa terá direito à liberdade de expressão; esse direito } \\
\text { incluirá a liberdade de procurar, receber e difundir informações e ideias de } \\
\text { qualquer natureza, independentemente de considerações de fronteiras, } \\
\text { verbalmente ou por escrito, em forma impressa ou artística, ou por qualquer } \\
\text { outro meio de sua escolha. }\end{array}$ \\
\hline $\begin{array}{c}1986 \text { - Carta Africana dos } \\
\text { Direitos Humanos e dos Povos }\end{array}$ & Artigo 9 - Toda pessoa tem direito à informação. \\
\hline $\begin{array}{l}1992 \text { - Convenção Americana } \\
\text { sobre Direitos Humanos }\end{array}$ & $\begin{array}{l}\text { Artigo } 13 \text { - Liberdade de Pensamento e de Expressão: Toda pessoa tem } \\
\text { direito à liberdade de pensamento e de expressão. Esse direito compreende a } \\
\text { liberdade de buscar, receber e difundir informações e ideias de toda natureza, } \\
\text { sem consideração de fronteiras, verbalmente ou por escrito, ou em forma } \\
\text { impressa ou artística, ou por qualquer outro processo de sua escolha. }\end{array}$ \\
\hline $\begin{array}{l}2000 \text { - Declaração } \\
\text { Interamericana de Princípios de } \\
\text { Liberdade de Expressão }\end{array}$ & $\begin{array}{l}\text { Princípio } \mathrm{n}^{\circ} 2 \text { - Toda pessoa tem o direito de buscar, receber e divulgar } \\
\text { informação e opiniões livremente, nos termos estipulados no Artigo } 13 \text { da } \\
\text { Convenção Americana sobre Direitos Humanos. Todas as pessoas devem } \\
\text { contar com igualdade de oportunidades para receber, buscar e divulgar }\end{array}$ \\
\hline
\end{tabular}




\begin{tabular}{|c|c|}
\hline & $\begin{array}{l}\text { informação por qualquer meio de comunicação, sem discriminação por } \\
\text { nenhum motivo, inclusive os de raça, cor, religião, sexo, idioma, opiniões } \\
\text { políticas ou de qualquer outra índole, origem nacional ou social, posição } \\
\text { econômica, nascimento ou qualquer outra condição social. }\end{array}$ \\
\hline $\begin{array}{l}2005 \text { - Convenção das Nações } \\
\text { Unidas contra a Corrupção }\end{array}$ & $\begin{array}{l}\text { Artigo } 13 \text { - Participação da Sociedade: Cada Estado Parte adotará medidas } \\
\text { adequadas, no limite de suas possibilidades e de conformidade com os } \\
\text { princípios fundamentais de sua legislação interna, para fomentar a } \\
\text { participação ativa de pessoas e grupos que não pertençam ao setor público, } \\
\text { como a sociedade civil, as organizações não governamentais e as } \\
\text { organizações com base na comunidade, na prevenção e na luta contra a } \\
\text { corrupção, e para sensibilizar a opinião pública a respeito à existência, às } \\
\text { causas e à gravidade da corrupção, assim como a ameaça que esta representa. } \\
\text { Essa participação deveria se esforçar com medidas como as seguintes: [...] b) } \\
\text { Garantir o acesso eficaz do público à informação. }\end{array}$ \\
\hline $\begin{array}{l}2008 \text { - Declaração de Atlanta e } \\
\text { Plano de Ação para o Avanço } \\
\text { do Direito de Acesso à } \\
\text { Informação }\end{array}$ & $\begin{array}{l}\text { Todo o documento trata da promoção do acesso à informação. A declaração é } \\
\text { resultado da International Conference the Right to Public Information , } \\
\text { encontro promovido pelo Carter Center e realizado em } 2008 \text { na cidade de } \\
\text { Atlanta, Estados Unidos. Participaram do encontro representantes de } 40 \text { países } \\
\text { do que a Declaração chama de membros da comunidade global de acesso à } \\
\text { informação. Havia, presentes ali, representantes de governos, organizações da } \\
\text { sociedade civil, organismos internacionais, instituições financeiras, agências e } \\
\text { fundações doadoras, empresas do setor privado, meios de difusão e } \\
\text { acadêmicos. }\end{array}$ \\
\hline
\end{tabular}

Quadro 1 - Legislação e declarações internacionais sobre o direito à informação.

Fonte: Inspirado em Dutra, 2015.

A Declaração Universal dos Direitos Humanos de 1948 coloca a questão do acesso à informação em âmbito mundial. Entretanto, desde 1766, a Suécia já contava com uma lei que garantia a seus cidadãos o acesso a informações públicas, tendo sido o primeiro país a regulamentar tal direito (Acess-info).

Na legislação sueca há, em seu texto original de 1766, uma ligação entre liberdade de imprensa e acesso à informação. A lei se inicia expondo os vetos ao que não pode ser impresso no país. No século XVIII, ainda com forte presença da religião na sociedade escandinava, o Artigo $1^{\circ}$ previa punição para quem ofendesse a religião cristã. Depois de tratar sobre liberdade de imprensa, passava-se ao direito a imprimir informações públicas. A lei lista uma série delas que podem ser acessadas e impressas como decisões do parlamento ou judiciais e estabelece, também, o que não pode ser impresso. Para definir regras claras, afirmava-se que tudo o que não estivesse proibida a divulgação, podia ser divulgado. Essa legislação junta liberdade de imprensa, liberdade de expressão e acesso à informação pública e já se encontra, nesse primeiro marco jurídico sobre a questão, a determinação de que a publicidade é a regra, e o sigilo, a exceção; tudo o que não estiver proibido de ser publicizado pode ser acessado e publicado.

O nome da norma jurídica já traz as intenções dos legisladores, trata-se da "Lei da 
Liberdade de Imprensa", em inglês The Freedom of Press Act. A legislação faz parte da base constitucional da Suécia, foi incorporada como uma das leis fundamentais daquele Estado junto com outras quatro que tratam das ações do governo, da sucessão na monarquia, da liberdade de expressão e das regras de funcionamento do parlamento ${ }^{2}$.

Desde sua criação, há mais de dois séculos, a lei sueca já era detalhada; porém, o citado Artigo XIX da Declaração Universal dos Direitos Humanos, aprovado em 1948, é amplo e, apesar de indicar um caminho, não regulamenta a questão do direito de acesso à informação pública. Entretanto, foi após esse posicionamento das Nações Unidas que se seguiu com a regulamentação desse direito em vários países. A Finlândia, em 1951, foi o primeiro (ANGÉLICO, 2012). No caso do Brasil, Souza (2013) diz que foi o $90^{\circ}$ país a aprovar tal legislação. Porém, Angélico (2012) afirma que a lei brasileira é a $89^{\circ}$. Neste trabalho tal questão não será discutida, por não ter relevância para o objeto desta pesquisa.

Para entender a situação atual das políticas de acesso à informação pública, é necessário conhecer o percurso histórico desse direito. Aqui se toma como ponto de partida a Magna Carta de 1215, na Inglaterra, e passa-se à Declaração de Independência dos Estados Unidos em 1776 e sua consequente Constituição em 1787 com a Primeira Emenda de 1791; depois, vai-se à Revolução Francesa em 1789. Esses são alguns marcos que o presente trabalho toma como importantes no percurso histórico da construção do direito de acesso à informação até a constituição da ONU e seus consequentes posicionamentos.

A Magna Carta de 1215 foi assinada pelo rei João, da Inglaterra. O texto do documento não trata, em nenhum momento, da liberdade de expressão de forma clara, entretanto, estabeleceu outras liberdades que impunham limites ao poder do monarca como a liberdade religiosa dos súditos e garantias de julgamentos para pessoas acusadas de crimes. $\mathrm{O}$ poder do rei foi submetido a um grupo do povo ${ }^{3}$. Cita-se aqui esse documento como marco histórico para o acesso à informação porque ele submeteu o rei ao escrutínio público, forçando o monarca a prestar contas, informar a um Conselho sobre suas ações ${ }^{4}$.

2 Todas as informações sobre a lei de acesso à informação da Suécia vieram de duas fontes, o parlamento sueco $<$ http://www.riksdagen.se/> e a Fundação Anders Chydenius <http://www.chydenius.net/>. Ambos os sites oferecem a possibilidade de acesso em língua inglesa. Portanto, as informações não foram lidas em sueco, o idioma original. No caso da Fundação Anders Chydenius, eles publicaram um livro sobre a Lei de Acesso à Informação sueca em 2006, em comemoração aos 240 anos da legislação. O livro está disponível em $<$ http://www.chydenius.net/pdf/worlds_first_foia.pdf> também traduzido do sueco para o inglês. Os três endereços eletrônicos citados aqui foram acessados em 13 de março de 2015.

3 Ao usar o termo povo, não se refere à população em geral, mas a membros da elite, da aristocracia inglesa da época, especificamente os barões.

4 Usa-se aqui o texto da Magna Carta já traduzido para o português e disponibilizado no site da Universidade de 
A Constituição dos Estados Unidos da América, de 1787, é outro ponto no avanço do direito de acesso à informação, pois foi a primeira constituição nacional que trouxe garantias de liberdades e eleições com o estabelecimento de uma República. A Declaração da Independência, em 1776; o estabelecimento da Constituição, em 1787; e a promulgação da $1^{\text {a }}$ Emenda, em 1791, fazem parte de um conjunto regulatório que garante a liberdade de imprensa e, consequentemente, de acesso à informação nos EUA que foi regulamentado em 1966. A Constituição estabeleceu a República, já a Primeira Emenda determinou a garantia da liberdade de imprensa. Todo esse conjunto de normas constituiu-se num processo gerador de acesso à informação e consequente transparência do Estado 5

A Declaração de Direitos do Homem e do Cidadão de 1789, resultado da Revolução Francesa, é outro momento que contribuiu para a construção do direito de acesso à informação. Esse documento traz, de forma clara, a garantia da liberdade de expressão e de opinião e, mais que isso, o Artigo 15 diz que a sociedade tem direito de pedir contas a todo agente público pela sua administração 6 .

Assim, é possível afirmar que, de 1215 ao século XX, o direito de acesso à informação passou de um direito civil - com a adoção de ideias em torno das liberdades de expressão e de imprensa em alguns poucos Estados da Europa Ocidental - para a dimensão de um direito social no qual os Estados se tornam garantidores do direito de acesso à informação e estabelecem políticas públicas para isso. Têm-se aqui os conceitos de direitos civil e social como expressados por Marshal (1967) ${ }^{7}$. Além do posicionamento da ONU, pode-se citar a grande expansão dos mass media como fator decisivo nesse tema, com suas ações que levaram as sociedades a serem mais abertas, mais transparentes.

São Paulo (USP) disponível em <http://www.direitoshumanos.usp.br/index.php/Documentos-anteriores\%C3\%A0-cria\%C3\%A7\%C3\%A3o-da-Sociedade-das-Na\%C3\%A7\%C3\%B5es-at\%C3\%A9-1919/magnacarta-1215-magna-charta-libertatum.html>. Acessado em 11 de março de 2015.

5 A Constituição dos Estados Unidos da América está, em português, no portal da Universidade de São Paulo (USP). Disponível em <http://www.direitoshumanos.usp.br/index.php/Documentos-anteriores-\%C3\%A0cria\%C3\%A7\%C3\%A3o-da-Sociedade-das-Na\%C3\%A7\%C3\%B5es-at\%C3\%A9-1919/constituicao-dosestados-unidos-da-america-1787.html> . Acesso em 11 de março de 2015.

6 Declaração Universal de Direitos do Homem e do Cidadão, acessado em 11 de março de 2015. Disponível em <http://www.direitoshumanos.usp.br/index.php/Documentos-anteriores-\%C3\%A0cria\%C3\%A7\%C3\%A3o-da-Sociedade-das-Na\%C3\%A7\%C3\%B5es-at\%C3\%A9-1919/declaracao-dedireitos-do-homem-e-do-cidadao-1789.html>.

7 Toma-se como direito civil aquele que o Estado garante com a sua não ação; o Estado não confisca a propriedade privada; o Estado não interfere no direito de crença; direito político é referido aqui como aquele em que o Estado se abre para os cidadãos e aí é citado o Parlamento, quando o indivíduo, por meio do voto, passa a interferir nos negócios do Estado; Por fim, caracteriza-se como direito social, a ação do Estado, aquele direito que, para existir, é necessário que o poder estatal se mova. No caso do acesso à informação, não basta que ele permita que o indivíduo fale o que quiser; não basta que ele permita que o indivíduo fale das coisas do Estado, ele, o poder estatal, precisa agir e garantir o acesso às informações públicas. 
Rememorando a história, é válido lembrar, também, que a ideia de democracia dos gregos, com a Ágora, pressupunha a existência do poder em público de forma direta e visível. Entretanto, verifica-se que essa prática do exercício do poder em público só era possível pelo fato de o Estado grego resumir-se a cidades-Estado, com uma democracia direta, mas da minoria. Nesse sistema democrático grego, o acesso à informação estava garantido com a presença física e a manifestação do cidadão na praça. Esse modelo da Antiguidade é, entretanto, um pequeno ponto na construção da democracia como poder na praça, poder em público.

Não pode haver democracia sem transparência. Bobbio (1986) afirma que a democracia é o poder visível, mas que há, por certo, também, o poder invisível, e a forma mais interessante de se colocar à prova a capacidade de o poder visível debelar o poder invisível é a publicidade dos atos do poder. Para ele, o verdadeiro momento da reviravolta na transformação do Estado moderno, que passa de Estado absoluto a Estado de direito, é o momento em que o poder está visível ou que se pretende que ele se torne visível (BOBBIO, 1986).

O Estado Moderno Liberal ${ }^{8}$ e o Estado de Direito, que substituíram o Estado Moderno Absolutista, requerem o poder visível. No absolutismo, o poder do monarca vinha de Deus, e Deus é, por sua definição de onisciência, inquestionável, logo, o poder do Estado era inquestionável e envolto em uma aura de mistérios. As decisões políticas, nesse contexto, eram tomadas longe dos olhos do povo, próximas apenas dos olhos da divindade de onde, justificava-se, provinha o poder dos reis.

A chegada do Estado Moderno Liberal, com a democracia, a sujeição dos monarcas ao poder terreno dos parlamentos ou mesmo a destituição de monarcas para a instauração de Repúblicas, coloca o Estado Moderno em público; o poder deixa de emanar de Deus e passa a emanar do povo; o chefe de Estado deixa de prestar contas a Deus e passa a prestar contas aos cidadãos. Essa transformação do Estado Absolutista para o Estado Moderno Liberal muda a visibilidade do poder e, em consequência, altera o fluxo de informações. Antes, reis e imperadores prestavam contas a Deus, seja por meio do clero ou nem isso, confundindo o

8 Para Carnoy, o Estado Liberal, Estado de Direito, surge acompanhado da ideia de democracia, nasce com o capitalismo. Neste trabalho, utilizou-se o conceito de Estado Liberal baseado nas ideias de Locke que defendia que, no Estado Moderno Liberal, os homens entregam seu poder "natural" a outrem que passa a governar. Entende-se, assim, que Bobbio (1986) ao tratar da transição do Estado Absolutista, que se compreende aqui como Estado Moderno, trata da transição do Estado Moderno Absolutista para o Estado Moderno Liberal. É no Estado Moderno Liberal com seu parlamento, Justiça e democracia que o poder precisa tornar-se visível. Ver mais em Estado e Teoria Política, Martin Carnoy, editora Papirus: São Paulo, 2011. 
Estado com o monarca. Agora é preciso que o poder vá à praça, que o rei vá ao parlamento, que envie relatórios, que informe. Essa mudança na cultura ocidental não se estabeleceu de forma fácil. Revoluções, guerras, revoltas, mudanças no pensamento, tudo isso fez parte da construção desse novo mundo. Jardim (1999) afirma que, se na monarquia de direito divino, a invisibilidade do poder real é uma exigência, no Estado moderno, o segredo é, por princípio, legitimado apenas nos casos excepcionais.

Wolton (2004) afirma que não é possível haver democracia no plano mundial sem que haja uma reflexão teórica sobre os desafios políticos, culturais, técnicos, antropológicos e sociais ligados à comunicação. Ele vê uma ligação direta entre a emancipação humana e a luta pela liberdade de informação. A liberdade de informação constitui premissa da liberdade de consciência, pois não pode o sujeito ter consciência sem receber informação.

Ao fazer essa reflexão teórica que Wolton sugere, percebe-se que, no campo cultural, a modernidade veio acompanhada, dentre outros pontos, da Reforma Protestante que culminou no século XVI e pode ser resumida de forma simplista, mas correta, que se tratava de um movimento que exigia, também, acesso à informação, antes monopolizada pela Igreja Católica. A Reforma mostrou sua força, especialmente no norte da Europa. Com tal mudança, parte do mundo cristão exigiu o direito de acesso aos conhecimentos guardados pela Igreja. Nesse contexto, as traduções de textos sagrados para línguas maternas e o acesso do povo aos saberes da Igreja constituem, assim, uma mudança cultural essencial para a construção do futuro direito ao conhecimento.

A técnica, também citada por Wolton (2004), contribuiu para esse momento. A imprensa - substituindo os manuscritos - e os meios de transporte - conseguindo pôr em circulação as informações - fizeram parte do contexto de mudança que auxiliou na construção das democracias. Outra vez, os períodos e os lugares em que esses fatores foram mais evidentes são os mesmos: o século XVI e o norte da Europa. A imprensa permitiu a produção de textos em grande escala. As linhas férreas e os canais de navegação permitiram que essas informações, agora impressas em grande quantidade, pudessem circular com mais rapidez e facilidade. Os manuscritos se transformaram em material impresso, desceram do cavalo e passaram a circular de trem ou de navios a vapor.

Por fim, Wolton pede uma reflexão antropológica e social a respeito dessa relação entre comunicação e democracia. Neste trabalho, é aceita a ideia de que na mudança da Idade Média para a Idade Moderna, o homem deixa Deus de lado e foca-se em si mesmo. Socialmente, há mudanças com o surgimento de um novo mundo, fazendo com que o direito 
ao saber se torne fundamental. Essa nova sociedade, a moderna, tem na livre leitura dos textos sagrados uma base para sua construção. Em regiões, como as atuais Holanda, Alemanha e Escandinávia, o protestantismo fortalecido forneceu uma nova mentalidade focada no acesso às informações religiosas. Com a liberdade de pensamento, a ciência também acabou por livrar-se da censura.

Esse novo mundo industrializado, a vapor, sobre trilhos, impresso e com grande avanço da alfabetização, compõe parte do cenário que levou o Ocidente daquela organização social medieval secretista à sociedade moderna e, por fim, à atual Sociedade do Conhecimento ${ }^{9}$, descrita por Manuel Castells.

É possível perceber uma ligação entre a sociedade que se construiu nos últimos séculos e o acesso à informação. Desde o fim da Idade Média, em seu longo processo de avanços e recuos, o acesso à informação e o direito ao saber estiveram no centro da constituição da sociedade a que se chegou atualmente. A luta por liberdade religiosa teve suas bases na busca e na divulgação do conhecimento, das informações.

Estudo das organizações não governamentais ANDI (Agência de Notícias dos Direitos da Infância) e Artigo $19^{10}$ afirmam que o direito à informação se configura na atualidade como o direito de todo indivíduo acessar informações públicas em poder do Estado. "Essa proposição tem como base a própria noção de democracia, vinculada à capacidade de os cidadãos participarem de forma efetiva dos processos de decisão que afetam diretamente suas vidas" (ANDI; Artigo 19, p. 5).

No mesmo estudo, afirma-se que não existe democracia "plena" se a informação estiver concentrada nas mãos de poucos. Para os autores desse trabalho, as instituições

9 Sociedade do Conhecimento ou Sociedade da Informação é definida por Manuel Castells como a sociedade em que a informação é o motor social, a tecnologia é a regente da organização humana em sociedade. Esse conceito e a aceitação, neste trabalho, de que se vive na Sociedade do Conhecimento é importante, pois as leis de acesso à informação pública são um instrumento de realocação do Estado nessa sociedade. Castells fala das sociedades informacionais, onde o Estado foi o motor da mudança do capitalismo industrial para o capitalismo informacional e também fala de Estados que falharam em promover essa mudança. Assim, entende-se que as Leis de Acesso à Informação Pública colocam à disposição da sociedade o conhecimento que o Estado produz, e o Estado produz poder, portanto as LAI's são distribuidoras de poder, e isso remete à velha afirmação de que "informação é poder". Em um capitalismo globalizado, onde os Estados se aliam a grandes corporações econômicas, e essas corporações tonam-se grande fonte de poder, capazes de dirigir o rumo de milhões de vidas humanas, a capacidade dos Estados em deter informações e a capacidade dos cidadãos em ter acesso a essas informações são essenciais para garantir a existência do Estado Liberal, do Estado de Direito, da democracia representativa. Ver mais em Castells, Manuel. A Sociedade em Rede. Paz e Terra: São Paulo, 2011.

10 O trabalho “Acesso à Informação e Controle Social das Políticas Públicas” foi publicado em 2009 pelas Organizações Não Governamentais Agência dos Direitos da Infância (Andi, Comunicação e Direitos) e Artigo 19 e está disponível em <http://www.andi.org.br/politicas-de-comunicacao/publicacao/acesso-a-informacao-econtrole-social-das-politicas-publicas>. Acessado em 30 de abril de 2015. 
provedoras de conhecimento e de informação sempre caminharam lado a lado com a ideia de uma sociedade democrática; eles citam como exemplo a escola, a imprensa e as bibliotecas que teriam sido sustentáculos das democracias das quais a ampliação do acesso à informação implica na consolidação e aprofundamento. Com base nesse argumento, pode-se afirmar que o percurso histórico do direito de acesso à informação está ligado ao percurso da democracia.

Vê-se que, historicamente, as leis de acesso à informação pública estão ligadas à maior participação social, à ideia de controle de políticas públicas por parte dos cidadãos e como medidas de combate à corrupção. A aprovação dessas legislações ganhou força a partir da última década do século XX. No Quadro 2, está a lista dos países que já aprovaram tais legislações.

\begin{tabular}{|c|c|c|}
\hline \multicolumn{3}{|c|}{ Lista dos países que já contam com uma legislação de acesso à informação } \\
\hline Criação das leis na linha do tempo & País & Ano de criação da lei \\
\hline Século XVIII & Suécia & 1766 \\
\hline Século XX, anos 50 (1950-1959) & Finlândia & 1951 \\
\hline Século XX, anos 60 (1960-1969) & Estados Unidos & 1966 \\
\hline \multirow[t]{4}{*}{ Século XX, anos 70 (1970-1979) } & Noruega & 1970 \\
\hline & Dinamarca & 1970 \\
\hline & Holanda & 1978 \\
\hline & França & 1978 \\
\hline \multirow[t]{6}{*}{ Século XX, anos 80 (1980-1989) } & Nova Zelândia & 1982 \\
\hline & Austrália & 1982 \\
\hline & Mongólia & 1983 \\
\hline & Colômbia & 1985 \\
\hline & Grécia & 1986 \\
\hline & Áustria & 1987 \\
\hline \multirow[t]{11}{*}{ Século XX, anos 90 (1990-1999) } & Itália & 1990 \\
\hline & Hungria & 1992 \\
\hline & Portugal & 1993 \\
\hline & Belize & 1994 \\
\hline & Bélgica & 1994 \\
\hline & Lituânia & 1996 \\
\hline & Coreia do Sul & 1996 \\
\hline & Islândia & 1996 \\
\hline & Tailândia & 1997 \\
\hline & Usbequistão & 1997 \\
\hline & Irlanda & 1997 \\
\hline
\end{tabular}




\begin{tabular}{|c|c|c|}
\hline & Israel & 1998 \\
\hline & Letônia & 1998 \\
\hline & Albânia & 1999 \\
\hline & Japão & 1999 \\
\hline & Trindade e Tobago & 1999 \\
\hline & República Tcheca & 1999 \\
\hline & Liechtenstein & 1999 \\
\hline & Geórgia & 1999 \\
\hline \multirow[t]{32}{*}{ Século XXI, anos 2000 (2000-2009) } & Bulgária & 2000 \\
\hline & Eslováquia & 2000 \\
\hline & Bósnia Herzegóvina & 2000 \\
\hline & África do Sul & 2000 \\
\hline & Estônia & 2000 \\
\hline & Reino Unido & 2000 \\
\hline & Moldávia & 2000 \\
\hline & Romênia & 2001 \\
\hline & Polônia & 2001 \\
\hline & México & 2002 \\
\hline & Zimbábue & 2002 \\
\hline & Jamaica & 2002 \\
\hline & Angola & 2002 \\
\hline & Panamá & 2002 \\
\hline & Paquistão & 2002 \\
\hline & Tajiquistão & 2002 \\
\hline & Peru & 2003 \\
\hline & Kosovo & 2003 \\
\hline & São Vicente e Granadinas & 2003 \\
\hline & Armênia & 2003 \\
\hline & Croácia & 2003 \\
\hline & Eslovênia & 2003 \\
\hline & Turquia & 2003 \\
\hline & Sérvia & 2003 \\
\hline & Equador & 2004 \\
\hline & Antígua & 2004 \\
\hline & Argentina & 2004 \\
\hline & República Dominicana & 2004 \\
\hline & Suíça & 2004 \\
\hline & Montenegro & 2005 \\
\hline & Azerbaidjão & 2005 \\
\hline & Índia & 2005 \\
\hline
\end{tabular}




\begin{tabular}{|c|c|c|}
\hline & Taiwan & 2005 \\
\hline & Alemanha & 2005 \\
\hline & Uganda & 2005 \\
\hline & Honduras & 2006 \\
\hline & Macedônia & 2006 \\
\hline & Nicarágua & 2007 \\
\hline & Quirguistão & 2007 \\
\hline & Nepal & 2007 \\
\hline & China & 2007 \\
\hline & Jordânia & 2007 \\
\hline & Malta & 2008 \\
\hline & Etiópia & 2008 \\
\hline & Indonésia & 2008 \\
\hline & Bangladesh & 2008 \\
\hline & Uruguai & 2008 \\
\hline & Chile & 2008 \\
\hline & Guatemala & 2008 \\
\hline & Ilhas Cook & 2009 \\
\hline & Rússia & 2009 \\
\hline Século XXI, anos 2000 (2010-2014) & Guiné & 2010 \\
\hline & Libéria & 2010 \\
\hline & Ucrânia & 2011 \\
\hline & Brasil & 2011 \\
\hline & Tunísia & 2011 \\
\hline & Nigéria & 2011 \\
\hline & El Salvador & 2011 \\
\hline & Niger & 2011 \\
\hline & Mongólia & 2011 \\
\hline & Iêmen & 2012 \\
\hline & Ruanda & 2013 \\
\hline & Espanha & 2013 \\
\hline & Serra Leoa & 2013 \\
\hline & Costa do Marfim & 2013 \\
\hline & Guiana & 2013 \\
\hline & Afeganistão & 2014 \\
\hline & Paraguai & 2014 \\
\hline & Maldivas & 2014 \\
\hline
\end{tabular}

Quadro 2: Lista dos países que já contam com uma legislação de acesso à informação.

Fonte: Global Right to Information Rating disponível em <http://www.rti-rating.org/country_data.php>, acessado em 17 de março de 2015. A partir dos dados dessa organização, este trabalho sistematizou as informações no quadro acima. 


\subsection{Acesso à informação no Brasil}

A lei brasileira que regulamenta o direito de acesso às informações públicas, Lei 12.527 de 2011 ou Lei de Acesso à Informação (LAI), é fruto de um contexto global que, como já citado, vem evoluindo desde o momento em que a Organização das Nações Unidas (ONU) proclamou o direito de acesso à informação como um direito humano. Na Constituição brasileira, o que se chama de Direitos Humanos na legislação internacional, recebe o nome de Direitos Fundamentais e está inscrito, em sua maioria, no Artigo $5^{\circ}$. Nesse artigo, em seu inciso XXXIII, está escrito que:

Todos têm direito de receber dos órgãos públicos informações do seu interesse particular, ou de interesse coletivo ou geral, que serão prestadas no prazo da lei, sob pena de responsabilidade, ressalvadas aquelas cujo sigilo seja imprescindível à segurança da sociedade e do Estado (BRASIL, CONSTITUIÇÃO 1988).

A Carta Magna brasileira considera tão importante a garantia de acesso à informação que criou um instrumento jurídico específico para garantir aos cidadãos esse acesso, se necessário, pela via judicial, mesmo antes de qualquer regulamentação. No inciso LXXII do 11 Art. $5^{\circ}$ foi instituído o habeas data . Desde a promulgação da Constituição Federal de 1988, várias legislações foram implementadas pelo Estado brasileiro para tratar do Artigo XXXIII da Constituição Federal. No Quadro 3, está uma síntese desses regulamentos.

\begin{tabular}{|l|l|}
\hline \multicolumn{1}{|c|}{ INSTRUMENTO NORMATIVO } & \multicolumn{1}{c|}{ CONTEÚDO } \\
\hline Lei 8.159/1991 & $\begin{array}{l}\text { Modificada pela LAI, a Lei 8.159/91, estabelece diretrizes da } \\
\text { política nacional de arquivos públicos e privados. Assegura a } \\
\text { todos o direito de acesso pleno a quaisquer documentos } \\
\text { públicos, sem definir como se daria tal acesso. Essa Lei } \\
\text { estabelece que o direito de acesso será pleno, com exceção } \\
\text { de papéis de caráter sigiloso, "cuja divulgação ponha em } \\
\text { risco a segurança da sociedade e do Estado" ou exponha } \\
\text { indevidamente a intimidade, a vida privada ou a imagem das } \\
\text { pessoas. }\end{array}$ \\
\hline Lei 9.051/1995 & $\begin{array}{l}\text { Trata da expedição de certidões para a defesa de direitos ou } \\
\text { esclarecimentos de situações, determinando que o prazo para } \\
\text { a expedição desses documentos é de, no máximo, 15 dias nos } \\
\text { órgãos da administração centralizada ou autárquica, empresas } \\
\text { públicas, sociedades de economia mista e fundações públicas } \\
\text { da União, dos Estados, do Distrito Federal e dos Municípios. }\end{array}$ \\
\hline Decreto Presidencial 2.134/1997 & $\begin{array}{l}\text { Criava as "Comissões Permanentes de Acesso". Revogado } \\
\text { pelo Decreto no } 4.553 / 2002, \text { que regulamentou o art. 23 da } \\
\text { Lei no }{ }^{\circ} \text { 8.159/1991, sobre a categoria dos documentos } \\
\text { públicos sigilosos e o acesso a eles. }\end{array}$ \\
\hline
\end{tabular}

11 O Glossário Jurídico do Supremo Tribunal Federal (STF) define Habeas Data como “ação para garantir o acesso de uma pessoa a informações sobre ela que façam parte de arquivos ou banco de dados de entidades governamentais ou públicas. Também pode pedir a correção de dados incorretos”. Disponível em <http://www.stf.jus.br/portal/glossario/verVerbete.asp?letra=H\&id=156>, acessado em 30 de abril de 2015. 


\begin{tabular}{|l|l|}
\hline Lei 9.507/1997 & $\begin{array}{l}\text { Regula o direito de acesso à informação existente em registro } \\
\text { ou banco de dados de caráter público e o procedimento do } \\
\text { Habeas Data. }\end{array}$ \\
\hline Decreto Presidencial 2.910/1998 & $\begin{array}{l}\text { Estabelece normas para a salvaguarda de documentos, } \\
\text { materiais, áreas, comunicações e sistemas de informação de } \\
\text { natureza sigilosa e dá outras providências. Este foi revogado } \\
\text { pelo Decreto no 4.553/2002. }\end{array}$ \\
\hline Decreto Presidencial 2.942/1999 & $\begin{array}{l}\text { Revogado pelo Decreto no 4.073/2002, versava sobre a } \\
\text { política nacional de arquivos públicos e privados. }\end{array}$ \\
\hline Decreto Presidencial 4.073/2002 & $\begin{array}{l}\text { Dispõe sobre o CONARQ (Conselho Nacional de Arquivos) } \\
\text { e SINAR (Sistema Nacional de Arquivos). Determina a } \\
\text { criação de Comissões Permanentes de Avaliação de } \\
\text { Documentos em cada órgão e entidade da Administração } \\
\text { Pública Federal. Regulamenta os arts. 7, 11 e 16 da Lei n } \\
8.159, \text { de 8 de janeiro de 1991, que dispõe sobre a política } \\
\text { nacional de arquivos públicos e privados. }\end{array}$ \\
\hline Decreto Presidencial 4.553/2002 & $\begin{array}{l}\text { Revoga o Decreto 2.134/1997. Determinava a possibilidade, } \\
\text { não mais existente, de sigilo eterno, pois permitia a } \\
\text { renovação indefinida do prazo máximo de 50 anos para a } \\
\text { não-divulgação de determinados documentos. O Decreto se } \\
\text { dedica à salvaguarda de dados, informações, documentos e } \\
\text { materiais sigilosos de interesse da segurança da sociedade e } \\
\text { do Estado, no âmbito da Administração Pública Federal, e dá } \\
\text { outras providências. }\end{array}$ \\
\hline
\end{tabular}

Quadro 3: Resumo do ambiente normativo brasileiro antes da publicação da Lei 12.527/2011.

Fonte: CGU (2011).

Apesar dessa sequência de normativas que foram implementadas desde a promulgação da Constituição de 1988, faltava ao Brasil uma lei ampla que regulamentasse o acesso às informações públicas. Essa lei veio em 2011, a partir da convergência de ações da sociedade civil e do governo.

Do lado da sociedade civil, foi criado, em 2003, o Fórum de Direito de Acesso às Informações Públicas $^{12}$ com o objetivo de agregar organizaçõos sem vínculo partidário e “pressionar o governo e a sociedade pela regulamentação do direito de acesso à informação pública" (Fórum de Direito de Acesso a Informações Públicas).

No ano de sua criação, 2003, o Fórum realizou o I Seminário Internacional de Direito

12 Compõem o Fórum as seguintes entidades: Associação Brasileira de Organizações Não-Governamentais (Abong); Associação Brasileira de Jornalismo Investigativo (Abraji); Associação Brasileira de Advogados Trabalhistas (Abrat); Associação dos Juízes Federais (Ajufe); Associação Latino-Americana de Advogados Trabalhistas (Alal); Amigos Associados de Ribeirão Bonito (Amarribo); Associação Nacional dos Magistrados da Justiça do Trabalho (Anamatra); Comunicação e Direitos (Andi); Associação Nacional de Jornais (ANJ); Associação Nacional dos Procuradores da República, (ANPR); Associação Paulista de Jornais, (APJ); Artigo 19; Associação Contas Abertas; Federação Nacional dos Jornalistas (Fenaj); Fórum Nacional de Dirigentes de Arquivos Municipais; Grupo Tortura Nunca Mais - RJ (GTNM-RJ); Instituto Brasileiro de Análises Sociais e Econômicas (Ibase); Instituto de Estudos Socioeconômicos (Inesc); Instituto Millenium; Movimento do Ministério Público Democrático (MPD); Ordem dos Advogados do Brasil (OAB); Projeto SOS Imprensa Faculdade de Comunicação da UnB; Rede Nacional de Observatórios de Imprensa (Renoi); Transparência Brasil; e Transparência Hacker. Todo esse conjunto de entidades da sociedade civil agiu de forma organizada por oito anos sobre o Congresso Nacional e o governo. 
de Acesso a Informações Públicas que aconteceu em Brasília. A segunda edição do evento ocorreu em 2009. Sob a coordenação da Associação Brasileira de Jornalismo Investigativo (Abraji), o Fórum trabalhou por oito anos em ações de pressão sobre o governo e o Congresso Nacional para que fosse aprovada uma lei de acesso à informação pública.

O grupo de entidades que compõem o Fórum é bastante variado, indo de associações de trabalhadores como a Federação Nacional dos Jornalistas (Fenaj) até uma entidade patronal, a Associação Paulista de Jornais (APJ). Há instituições ideologicamente identificadas com a esquerda, Grupo Tortura Nunca Mais - RJ (GTNM-RJ), e com a direita, Instituto Millenium. Essa abrangência ideológica aponta para a importância que o tema ganhou, no Brasil, na primeira década do século XXI.

Do lado do governo, a posse do novo presidente da República, Luiz Inácio Lula da Silva, em janeiro de 2003, levou ao Poder Executivo Federal políticos que fizeram oposição à Ditadura Civil-Militar no Brasil (1964-1985) e que tinham, por sua luta histórica, interesse em revelar informações do Estado brasileiro dos tempos do regime ditatorial que permaneciam secretas. Esse interesse se mostrou, por exemplo, nos esforços dos governos de Lula e da presidenta Dilma Rousseff para criar e manter o funcionamento da Comissão Nacional da Verdade (CNV). Essa disposição em revelar a memória do País culminou na aprovação da Lei 12.528/2011 que criou a CNV e também na aprovação da Lei de Acesso à Informação, Lei $12.527 / 2011$.

Melo reforça a ideia de que a LAI é fruto de um momento político em que a busca pela verdade histórica moveu ações do governo e da sociedade. Ao escrever sobre a aprovação da Lei, ele diz:

\footnotetext{
Além da transparência dos documentos em movimento hoje, ela regula o acesso a documentos de arquivos produzidos na época da ditadura civil-militar brasileira (1964-1985). Ou seja, dá mais um passo na longa caminhada de abertura de arquivos do período e contribui para que a história seja revista e rediscutida (MELO, Revista de História, 2012).
}

Reis (2014) aponta que a presidenta da República, Dilma Rousseff, se envolveu pessoalmente, não apenas na aprovação da LAI, mas também em sua implementação. Em entrevista dada àquela pesquisadora, o secretário-executivo do Ministério das Comunicações no ano de 2013, Danilo Marasca Bertazzi, afirma que, em reunião com secretários executivos de ministérios, no Palácio do Planalto, Dilma deixou claro que queria a Lei funcionando. "Logo no começo da fase de implementação da LAI, todos os secretários executivos da Esplanada foram chamados, e o recado foi dado pela presidenta Dilma Rousseff: a LAI vai ter 
de funcionar!", afirmou Bertazzi a Reis.

A primeira ação efetiva dos governos Lula (2003-2010) e Dilma (2011-201?) no sentido de criar uma lei de acesso à informação no Brasil veio somente em 2009, quando o então presidente Luiz Inácio Lula da Silva enviou à Câmara dos Deputados o Projeto de Lei (PL) 5.228/2009. Segundo Reis (2014), essa proposta foi gestada na Controladoria-Geral da União (CGU) ${ }^{13}$.

A Câmara dos Deputados criou uma Comissão Especial para analisar a proposta. Durante os trabalhos da Comissão, outros projetos de lei que tratavam do mesmo tema foram sendo reunidos ao PL do Executivo. Foram agregados o PL 219/2003 do deputado Reginaldo Lopes (PT-MG); o PL 1.019/2007 de autoria do deputado Celso Russomanno (PP-SP) e o PL 1.924/2007 do deputado Chico Alencar (PSOL-RJ).

O projeto enviado pelo governo era mais amplo e mais detalhado que os dos parlamentares. Para se ter uma ideia, a proposta de Reginaldo Lopes tinha 21 artigos, a de Celso Russomanno era composta por quatro e o projeto de Chico Alencar contava com oito. Já a medida enviada pelo governo continha 40 artigos e era mais detalhada com o estabelecimento de prazos e incorporando conceitos jurídicos internacionalmente já reconhecidos pela comunidade que lida com a questão do acesso à informação.

Ao final das análises e debates realizados na Comissão Especial da Câmara dos Deputados, seu presidente, José Genoíno (PT-SP), e o relator, Mendes Ribeiro (PMDB-RS), apresentaram um texto para substituir a proposta do Executivo. Esse texto foi aprovado no plenário da Câmara em 24 de fevereiro de 2010 e seguiu para o Senado, onde foi renomeado como PLC 41/2010.

Entre abril de 2010 e abril de 2011, o projeto de lei de acesso a informações públicas (PLC 41/2010) foi aprovado em três comissões do Senado: Constituição e Justiça; Direitos Humanos e Participação Legislativa e; Ciência, Tecnologia, Inovação, Comunicação e Informática.

Ao chegar à Comissão de Relações Exteriores, já em abril de 2011, o andamento do projeto travou. O presidente da Comissão, senador Fernando Collor de Mello (PTB-AL),

13 Criada em 28 de maio de 2003, com a publicação da Lei no 10.683, a Controladoria-Geral da União (CGU), é uma agência anticorrupção do País. Está encarregada de assistir direta e imediatamente ao Presidente da República no desempenho de suas atribuições quanto aos assuntos que, no âmbito do Poder Executivo, sejam relativos à defesa do patrimônio público e ao incremento da transparência da gestão, por meio das atividades de controle interno, auditoria pública, correição, prevenção e combate à corrupção, e ouvidoria. A CGU é ainda órgão central do Sistema de Controle Interno e do Sistema de Correição, ambos do Poder Executivo Federal. Definição dada pela própria CGU disponível em <http://www.cgu.gov.br/sobre/institucional/historico $>$. Acessado em $1^{\circ}$ de maio de 2015. 
levou quatro meses para assumir a relatoria da matéria. Caberia a ele indicar um relator o que não fez por cerca de 120 dias, por fim, assumiu, ele mesmo, a relatoria. O alagoano apresentou um substitutivo ao texto aprovado pelos deputados, propondo alterações que, se adotadas, provocariam o retorno do projeto de lei à Câmara. Entre as mudanças, o senador sugeriu que o sigilo de documentos oficiais fosse mantido por tempo indeterminado, o que na prática significaria o sigilo eterno.

Houve questionamentos na imprensa sobre a postura do parlamentar por ser ele expresidente da República e, supostamente, ter interesse em evitar que informações do seu governo fossem tornadas públicas (MALTCHIK, 2011). O também ex-presidente da República e, à época, presidente do Senado, José Sarney (PMDB-AP), resistiu à aprovação da LAI. Para Sarney, a divulgação de documentos secretos poderia "abrir feridas" (BRESCIANI, 2011).

Mesmo com a resistência dos dois senadores ex-presidentes da República, foi determinado o cumprimento do Regimento Interno do Senado Federal e a votação do projeto em turno único, por causa do regime de urgência no qual ele tramitava.

Houve, apesar do regime de urgência, manobras e adiamentos que impediram os planos do governo de que a presidenta Dilma Rousseff sancionasse a LAI antes de viajar para fazer seu primeiro discurso na Assembleia Geral da ONU, onde comporia, junto aos Estados Unidos, a liderança de um programa que trata de governo aberto, o Open Government Partinership $(O G P)^{14}$ ou Aliança para o Governo Aberto, e para o qual o Brasil havia sido convidado pela primeira vez. Iniciada com oito países, a aliança conta atualmente com 63 $\operatorname{membros}^{15}$. O Brasil, ao compor o grupo, assumiu um conjunto de compromissos ${ }^{16}$ que estão a cargo da CGU executar. Dentre esses, estão a manutenção do Portal da Transparência e o acompanhamento da implantação e do cumprimento da Lei de Acesso à Informação nas instituições públicas.

Nesse contexto, sob pressão do governo e da bancada de senadores do PT, o projeto da LAI foi aprovado no Plenário do Senado na noite de 25 de outubro de 2011. A presidenta

14 O Open Government Partinership é uma aliança, lançada em 2011, que visa a promover uma plataforma internacional de reformas domésticas que levem os governos a prestarem contas, serem mais abertos e melhorarem sua capacidade de resposta aos cidadãos.

15 Informações retiradas do site da Instituição <http://www.opengovpartnership.org/>. Acessado em 12 de abril de 2014.

16 Os países que compõem o OGP endossam uma Declaração de Princípios e apresentam Planos de Ação Nacionais. Os países-membros pautam seus planos a partir de cinco desafios: Melhoria dos Serviços Públicos, Aumento da Integridade Pública, Gestão mais Efetiva dos Recursos Públicos, Criação de Comunidades mais Seguras e Aumento da Responsabilidade Corporativa. 
Dilma Rousseff sancionou a Lei 12.527 em 18 de novembro de 2011 que entrou em vigor seis meses depois, em 16 de maio de 2012.

No Poder Executivo Federal, coube à Controladoria-Geral da União coordenar a implantação da lei, oferecendo capacitação aos servidores públicos e emitindo normatizações, (Decreto 7.724 de 16 de maio de 2012). Também foi responsabilidade da CGU a criação do SIC ou Sistema de Informações ao Cidadão, inclusive em sua versão virtual o e-SIC. Esse sistema informatizado administra todos os pedidos de informação feitos a órgãos públicos do Poder Executivo Federal. Por meio dele, qualquer interessado pode, depois de fazer um cadastro, solicitar informações aos órgãos que deseja. Feito o pedido, o governo tem até 20 dias para responder. Caso não seja possível cumprir esse prazo, o serviço público pode prorrogar por mais 10 dias.

Se não houver resposta à informação solicitada ou essa vier incorreta, o interessado pode, por meio do próprio sistema virtual, recorrer do posicionamento do órgão. Se ocorrer outra negativa, pode haver um recurso de segunda instância. Persistindo a posição do órgão público em negar o acesso, pode-se recorrer à CGU. Por fim, a última instância administrativa para recurso é a Comissão Mista de Reavaliação de Informações (CMRI).

A CMRI é um órgão colegiado interministerial que tem por finalidade rever a classificação, prorrogação e os recursos sobre pedidos de desclassificação de informações no grau ultrassecreto ou secreto, além de decidir os recursos apresentados contra as decisões de $3^{\mathrm{a}}$ instância da Controladoria-Geral da União relativas aos pedidos de acesso à informação. A Comissão também tem a atribuição de estabelecer orientações normativas a fim de suprir eventuais lacunas na aplicação da legislação relacionada com o acesso à informação.

São competências da CMRI, segundo o art. 47 do Decreto 7.724/2012:

- Rever, de ofício ou mediante provocação, a classificação de informação no grau ultrassecreto ou secreto ou sua reavaliação, no máximo a cada quatro anos;

- Requisitar da autoridade que classificar informação no grau ultrassecreto ou secreto esclarecimento ou conteúdo, parcial ou integral, da informação, quando as informações constantes do Termo de Classificação de Informação (TCI) não forem suficientes para a revisão da classificação;

- Decidir recursos apresentados contra decisão proferida:

a) pela Controladoria-Geral da União, em grau recursal, a pedido de acesso à informação ou às razões da negativa de acesso à informação; ou 
b) pelo Ministro de Estado ou autoridade com a mesma prerrogativa, em grau recursal, a pedido de desclassificação ou reavaliação de informação classificada;

- Prorrogar por uma única vez, e por período determinado não superior a vinte e cinco anos, o prazo de sigilo de informação classificada no grau ultrassecreto, enquanto seu acesso ou divulgação puder ocasionar ameaça externa à soberania nacional, à integridade do território nacional ou grave risco às relações internacionais do País, limitado ao máximo de cinquenta anos o prazo total da classificação; e

- Estabelecer orientações normativas de caráter geral a fim de suprir eventuais lacunas na aplicação da Lei 12.527/2011.

A CMRI é composta pelos titulares dos seguintes órgãos:

I - Casa Civil da Presidência da República, que a preside;

II - Ministério da Justiça;

III - Ministério das Relações Exteriores;

IV - Ministério da Defesa;

V - Ministério da Fazenda;

VI - Ministério do Planejamento, Orçamento e Gestão;

VII - Secretaria de Direitos Humanos da Presidência da República;

VIII - Gabinete de Segurança Institucional da Presidência da República;

IX - Advocacia-Geral da União;

X - Controladoria-Geral da União.

Os respectivos ministros podem indicar suplentes para a Comissão. Todo o processo, do pedido de informação ao órgão público, do inicial até o recurso à CMRI ocorre via sistema informatizado, porém, pode ser realizado em unidades físicas do SIC que são obrigatórias em todos os órgãos públicos.

\subsection{As mudanças que a LAI propõe}

O Inciso IV do Artigo $3^{\circ}$ da Lei de Acesso à Informação afirma que é uma das diretrizes da LAI fomentar a cultura da transparência na administração pública, mas como é o cenário atual nessa Administração? 
Jardim (1999) afirma que há uma opacidade estrutural no Estado brasileiro que resiste aos governos e mesmo aos regimes, sejam democráticos ou autoritários. A informação, diz ele, é usada como um instrumento de dominação e construção da hegemonia das classes dominantes sobre as dominadas. Existe no Brasil, de acordo com esse autor, uma desigualdade na distribuição das informações públicas. Além dessa desigualdade na distribuição, há também uma mistura do público com o privado na gestão das informações (JARDIM, 1999).

A LAI pretende superar essa cultura do sigilo e promover a cultura do acesso. "A implementação de um sistema de acesso à informação tem como um de seus principais desafios a superação da cultura do segredo que permeia a administração pública" (CGU, 2012a). Há, por parte dos servidores públicos, o receio de que as informações por eles disponibilizadas possam ser utilizadas para fins políticos, além da crença de que a disponibilização de informações aumentaria a demanda por trabalho no serviço público (JARDIM, 1999).

As políticas públicas relativas à LAI podem ser divididas em dois modos de implantação, transparência passiva e transparência ativa. Mendel (2009) afirma que, além de fornecer as informações solicitadas (transparência passiva), cabe ao Estado implementar ações proativas que garantam o livre acesso às informações públicas (transparência ativa).

A Cartilha de Acesso à Informação Pública, organizada pela Controladoria Geral da União (CGU, 2012b), define transparência passiva como aquela em que "a Administração Pública divulga informações sob demanda da sociedade", (CGU, 2012b, p.24). Já a transparência ativa é definida como aquela em que "a Administração Pública divulga informações à sociedade por iniciativa própria, de forma espontânea, independente de qualquer solicitação" (CGU, 2012b, p. 24).

A LAI estabelece quais são as informações mínimas que devem ser disponibilizadas na transparência ativa. Diz a lei, no caput do seu Artigo $8^{\circ}$ : “os órgãos e entidades públicas devem promover, independentemente de requerimentos, a divulgação em local de fácil acesso, no âmbito de suas competências, de informações de interesse coletivo ou geral por eles produzidas ou custodiadas" (Lei 12.527/2011).

Em seguida, no Parágrafo $1^{\circ}$ do Artigo $8^{\circ}$, está uma lista com as informações mínimas que devem ser disponibilizadas, são elas:

I - registro das competências e estrutura organizacional, endereços e telefones das respectivas unidades e horários de atendimento ao público; 
II - registros de quaisquer repasses ou transferências de recursos financeiros;

III - registros das despesas;

IV - informações concernentes a procedimentos licitatórios, inclusive os respectivos editais e resultados, bem como a todos os contratos celebrados;

$\mathrm{V}$ - dados gerais para o acompanhamento de programas, ações, projetos e obras de órgãos e entidades; e

VI - respostas a perguntas mais frequentes da sociedade. (LEI 12.527, DE 18 DE NOVEMBRO DE 2011, ART. $8^{\circ}$, PARÁGRAFO $1^{\circ}$ ).

A lei brasileira, por ter sido aprovada depois de várias legislações de outros países, trouxe avanços que muitas das demais não têm, dentre esses avanços, pode-se citar a adoção do conceito de transparência ativa. A lei de acesso à informação pública mais antiga do mundo, a sueca, não traz essa questão conforme afirmou o jornalista sueco Erik Jennische ao portal Contas Abertas 17 .

Analisando em detalhes a LAI e suas regulamentações, tem-se a impressão de que ela pretende colocar a administração pública brasileira em uma caixa de vidro, pois há detalhes nas regulamentações que expõem a gestão e os gestores públicos quase que em uma forma de transmissão televisiva de reality show. Veja-se o exemplo da exigência de que os chefes de órgãos públicos do poder executivo federal devam divulgar suas agendas, citando os nomes dos recebidos ou visitados, qual assunto tratado, quais os objetivos do encontro a se realizar e quais objetivos foram alcançados após a realização. Essa é uma informação que a LAI considera como transparência ativa. Seguindo-se a lei, a presidenta da República precisaria expor no site do Palácio do Planalto todas as conversas que tem com seus ministros. A exceção ficaria para os assuntos classificados como sigilosos.

Para entender as formas como a LAI poderá modificar a cultura do segredo nas instituições públicas, é preciso conhecer o histórico do direito de acesso à informação no Estado brasileiro. Neste contexto, Estado é tido como a estrutura burocrático-institucional que compõe a administração do País. Jardim (1999) afirma que esse Estado tem uma cultura de não publicização. A imprensa foi proibida no Brasil até $1808^{18}$ quando a colônia foi alçada à categoria de Reino Unido a Portugal e Algarves. Após esse evento, teve início um período no qual se registraram diversas ações para implantar a imprensa no País, todas controladas, de alguma forma, pela monarquia. Essa liberdade de imprensa não se tratava de um Estado que se abria à sociedade como se faz agora com a LAI, tratava-se de um Estado que falava pouco

17 “Com lei de acesso mais antiga do mundo, suecos têm confiança na política nacional”, acessado em 27 de julho de 2014, disponível em <http://www.contasabertas.com.br/website/arquivos/1136>.

18 As informações sobre a história da imprensa no Brasil foram retiradas do site da Imprensa Nacional, em várias de suas páginas. O acesso à página inicial permite ao usuário ir buscando informações históricas <http://portal.in.gov.br/>, acessado em 03 de novembro de 2014. 
de si, falava apenas o que queria e proibia os outros de se expressarem.

Entretanto, o Estado, por mais que queira evitar a exposição, é obrigado a mostrar-se em determinada medida, seja nas aparições públicas dos monarcas, seja na publicação das leis. A publicização de leis é, possivelmente, a forma mais antiga de o Estado se mostrar.

Pode-se afirmar que a primeira ação de transparência ativa estruturada em imprensa nas terras brasileiras pós-coloniais foi a publicação da Gazeta do Rio de Janeiro, o atual Diário Oficial da União. O órgão foi implantado pelo príncipe regente, Dom João VI, em 13 de maio de 1808 e publicava leis, alvarás, odes e orações. Fazia o papel de palavra do Estado, algo como um veículo institucional, e de imprensa.

A proclamação da independência do Brasil, em 1822, trouxe mudanças nesse quadro de secretismo do Estado. A Constituição de 1824, a primeira brasileira, apesar de imposta pelo imperador Dom Pedro I, alterou o quadro da visibilidade do poder. A liberdade de imprensa foi garantida. A criação do parlamento nacional, do poder judiciário e o estabelecimento de um contexto com mais liberdade para a fundação e a atuação dos jornais passou a colocar, em alguma medida, o Estado em público. As eleições restritas aos homens ricos e livres também representaram, naquele momento, um avanço frente ao antigo regime absolutista português. Não se encontrava na Constituição do Império normas semelhantes às regras das leis de acesso que visassem a mudar o quadro de exposição do Estado diante da sociedade, porém, a liberdade de imprensa permitia que o Estado fosse mais visto, os jornais podiam criticar o governo, apresentar denúncias, e qualquer cidadão poderia peticionar perante o aparato 19 estatal . O Estado brasileiro continuava com a Imprensa Oficial que funcionava, ainda, exercendo os papéis de Diário Oficial como o é hoje, mas também agia como imprensa.

A chegada da República não alterou esse quadro de forma a promover grandes transformações. Apenas a Revolução de 1930, com a criação do Departamento de Imprensa e Divulgação (DIP), trouxe uma mudança efetiva nesse modelo de comunicação do Estado herdado da monarquia. Antes do DIP, vale ressaltar que o presidente Nilo Peçanha criou, em 1909, um setor no Ministério da Agricultura responsável por se comunicar com a imprensa (DUARTE, 2002). Essa ação do Ministério da Agricultura pode ser considerada a primeira assessoria de comunicação em um órgão público no País, mas foi um ato isolado.

No entendimento adotado aqui, desse histórico do Estado brasileiro, o que marcou a mudança no acesso às informações estatais foi o DIP que, no governo Getúlio Vargas, tinha a

\footnotetext{
19 Constituição do Império do Brasil, disponível em <http://www.planalto.gov.br/ccivil_03/constituicao/Constituicao24.htm>. Acessada em 5 de novembro de 2014.
} 
missão, não apenas de expor o que o governo queria que fosse exposto, mas também de esconder o que não queria que fosse visto. O DIP levava informações por meio do rádio e do Diário Oficial e trouxe uma novidade para o Brasil independente, a censura como política de Estado. O rádio teve papel fundamental nesse momento da comunicação praticada pelo governo brasileiro. O DIP falava o que o governo queria que fosse falado e calava as informações que não queria ver públicas. A primeira grande ação de comunicação da República brasileira estava baseada, não na transparência, mas na censura, com o presidente Getúlio Vargas usando o rádio para defender o Estado nacional e seus interesses políticos.

Os governos democráticos que se seguiram ao fim do Estado Novo, a partir de 1946, não trouxeram grandes mudanças no cenário de sigilo estatal. No entanto, a censura foi suspensa.

Em 1964, o Estado brasileiro, com seu histórico de não abertura, fechou-se mais ainda e continuou a falar por meio do Diário Oficial, do rádio e estabeleceu políticas de comunicação, como, por exemplo, a expansão da televisão e do sistema de telecomunicações. As emissoras de televisão e rádio e os jornais, sob censura, não falavam das entranhas do Estado, e a administração pública escondia o que lhe conviesse e falava o que lhe beneficiava.

A redemocratização na década de 1980 alterou esse cenário, como em outros momentos de ruptura histórica das ditaduras para a democracia, ocorreu o fim da censura. Entretanto, o Estado continuou fechado, secreto, sem grandes mudanças na sua cultura de comunicar-se.

A Constituição de 1988 criou bases que foram alterando esse quadro, como a exigência de participação popular na gestão pública; a instituição do Ministério Público em seu modelo atual; e o Artigo 37 da Constituição, especialmente seu parágrafo primeiro com as regras para a publicidade estatal. Tudo isso deu início às mudanças nesse cenário de secretismo do Estado brasileiro. Entretanto, trata-se de mais de 500 anos de história em que o aparato estatal presente no Brasil, seja o português ou o brasileiro, esteve sempre voltado para si mesmo ${ }^{20}$, sem compromissos com a transparência. É nesse quadro histórico que a LAI se insere.

\subsection{LAI no Brasil: primeiros momentos de implantação de uma política}

Em 16 de maio de 2012, passou a vigorar em todo o território brasileiro a Lei

20 Quando se afirma que o Estado brasileiro esteve sempre voltado para si mesmo, significa que ele não se estrutura para atender à sociedade toda, mas apenas às elites locais. 
12.527/2011. Essa nova legislação pretende resolver um problema histórico do País, o privilégio de acesso às informações públicas, que sempre prejudicou os grupos socialmente excluídos.

A manifestação de um gestor da Lei de Acesso à Informação, obtida em uma entrevista para esta pesquisa, dá uma pequena demonstração de como era tratado e violado, no ambiente da administração governamental, o direito do cidadão a ter acesso às informações públicas do seu interesse. Diz ele, "eu sou do tempo em que, para pegar um número do PIS (Programa de Integração Social) na Caixa Econômica Federal, você ia até lá num dia e o servidor público te respondia, 'volta aqui amanhã que eu te passo esse número'. Isso agora é na hora”. Esse mesmo entrevistado atribui essa mudança a dois fatores: o avanço da tecnologia e as mudanças na administração do Estado.

Este estudo permitiu perceber que os avanços tecnológicos foram essenciais à ampliação do acesso à informação. Entretanto, a LAI também está colocando a questão no dia a dia do serviço público, na prática dos servidores. Com a entrada em vigor da Lei, a Controladoria-Geral da União assumiu a responsabilidade por gerir todo um complexo sistema que visa a administrar o acesso às informações públicas sob controle do Poder Executivo federal. Outra entrevistada para esta pesquisa opina que, "se a CGU não tivesse assumido esse papel, de chamar para si a responsabilidade de coordenar as ações, não teria sido possível colocar a lei em prática de forma tão rápida como foi”.

Aprovada a lei e seu decreto regulamentador, coube à CGU, dentre outras coisas:

- Elaborar manuais de aplicação da lei;

- Criar um sistema virtual de pedido de informações e de respostas que pode ser acessado a partir de qualquer computador ligado à internet;

- Capacitar os funcionários que aplicariam a lei e;

- Estabelecer uma forma de controle sobre o sistema onde se prevê prazos, recursos e determinações de ordens a órgãos subordinados.

Esse sistema, administrado pela CGU, aplica-se a todos os órgãos do Poder Executivo federal. Isso significa que qualquer informação pública que se queira e que esteja sob poder da Presidência da República pode ser pedida com alguns cliques no computador, não importa em que parte do País esteja o interessado ou a informação.

Para compreender os passos iniciais de aplicação da LAI, antes de entrar no ponto central deste trabalho, foram estabelecidas duas formas de observação desse primeiro momento de implantação da política coordenada pela CGU. Numa primeira ação, utilizou-se 
o sistema de pedidos de informação da LAI, o e-SIC; assim, foram enviadas perguntas para as 42 instituições pesquisadas. Num segundo momento, debruçou-se sobre os relatórios que a CGU divulga periodicamente sobre o SIC. São essas duas experiências de aproximação que seguem relatadas neste subcapítulo 1.3.

Logo no início dos levantamentos, em 2013, foram feitos pedidos de informações para todas as 42 instituições que compõem a Rede Federal de Educação, Ciência e Tecnologia. Isso significa que as solicitações foram enviadas para órgãos públicos dos 26 Estados e do Distrito Federal, espalhados por 37 cidades brasileiras, sendo 27 capitais e 10 cidades do interior ou 21 áreas metropolitanas .

Em alguns casos, as respostas tardaram por mais de um ano; em dois, não chegaram até este momento quando a dissertação está sendo concluída, dois anos depois de feitos os pedidos. Vale ressaltar que o prazo máximo para o poder público responder, segundo a Lei, é de 30 dias, já contando a prorrogação. Houve instituições que alegaram não ser possível enviar as informações, pois a quantidade de papéis, material físico, era muito grande, não podendo ser transportada digitalmente; outras enviaram o material no formato CD-Rom, via Correios, sem custos, houve os que digitalizaram tudo e disponibilizaram em uma pasta em nuvens; por fim, dois órgãos públicos informaram que os dados estavam disponíveis, mas que o usuário deveria se deslocar até a sede do órgão para poder acessá-los.

Verificou-se, nesse primeiro contato com o SIC, que não há uma uniformização nas ações e falta a determinados órgãos públicos, tanto boa vontade em atender o cidadão como conhecimento, por parte dos servidores, das tecnologias da informação que podem ser utilizadas para distribuir os dados. Esse contato inicial com o e-SIC serviu para uma interação entre o pesquisador e o sistema.

Depois de realizada essa primeira aproximação, o trabalho foi sendo construído e foi possível aprofundar um pouco mais no funcionamento da LAI. Porém, esta pesquisa fez um recorte da política de acesso à informação estabelecida com a lei. Na intenção de afastar desse recorte e conseguir ter uma visão ampla dessa legislação e sua política, após realizar as

21 Foram enviados nos meses de junho e julho de 2013 dois pedidos de informação a cada uma das 42 instituições que compõem a Rede Federal de Educação, Ciência e Tecnologia. $O$ primeiro pedido questionava quantos servidores atuavam com a LAI e se já havia uma Ouvidoria implantada na instituição. No segundo pedido, foram solicitadas todas as perguntas e respectivas respostas dos pedidos de informação realizados entre os dias 16 de maio de 2012 e 16 de maio de 2013. O primeiro objetivo da ação foi testar o funcionamento do e-SIC e, no segundo pedido, procurou-se verificar como as instituições conseguiam lidar com pedidos cujas respostas requeriam grande quantidade de informações. Todas as respostas foram utilizadas para embasar esta pesquisa, os números de quantos servidores atuavam em cada setor da LAI, por exemplo, embasaram a construção das entrevistas para as fases posteriores da pesquisa. 
entrevistas com os operadores da LAI e da comunicação, em outubro de 2014, optou-se por olhar os dados gerais da Lei de Acesso à Informação. A CGU publica regularmente relatórios sobre o funcionamento do e-SIC, então, buscou-se analisar esses relatórios para ter uma segunda aproximação com a política estabelecida. Se, em 2013, no início da pesquisa, foi possível realizar as primeiras interações com o e-SIC, no segundo semestre de 2014, com maior conhecimento sobre a lei e suas políticas, realizou-se uma análise dos dados da CGU antes de partir para o processamento dos dados levantados em campo nas entrevistas. Por ter sido essa análise fundamental na construção da relação com os dados levantados, considerouse correto incluí-la neste primeiro capítulo, para que o leitor acompanhe o passo a passo desta pesquisa que, depois de passar por um primeiro contato com o e-SIC, foi a campo levantar dados e, antes de tentar compreender esses dados levantados, objetivou-se ter uma visão geral de como estava a política de acesso à informação.

Entre maio de 2012 e setembro de $2014^{22}$, o poder executivo federal recebeu, por meio do SIC (Sistema de Informações ao Cidadão), 211.902 pedidos de informação e deu algum tipo de resposta, mesmo que negando o acesso a 210.304. O número de pedidos de informação apresentados não guarda relação direta com o número de cidadãos que os realizaram. Dessa forma, os 211.902 mil pedidos foram realizados por 121.971 pessoas, o que significa que apenas $0,06 \%$ dos brasileiros usaram o sistema, considerando o Censo 2010 do IBGE. Cada pedido de informação pode conter várias perguntas, assim 306.245 perguntas estavam embutidas nesses mais de 211 mil pedidos de informação.

Apesar de ser um número expressivo, quando comparado à quantidade de pessoas legalmente aptas a utilizar o sistema, cerca de 200 milhões, o número é pequeno. Um dos entrevistados para esta pesquisa justifica esse pouco uso da LAI com a expressão "não pegou”. Na avaliação desse entrevistado, a grande maioria da população não sabe como utilizar a lei ou nem mesmo sabe da sua existência. Por isso, diz ele, a lei não pegou. Quando da promulgação da lei e da consequente implantação da política de acesso à informação, o governo federal não lançou campanhas de divulgação nos meios de comunicação de massa. Essa situação deixou a lei e sua política à margem do grande público que poderia utilizá-la.

Quando se observam os dados do relatório da CGU nos seus detalhes, encontram-se situações como o fato de um único interessado fazer 1.382 pedidos, o que pode apontar para uma concentração do uso do sistema, quer dizer, determinados grupos continuam tendo mais acesso aos dados públicos que a grande maioria da população. Essas relações entre pedidos de 
informação e grupos de interessados têm um recorte de classe, de região, de escolaridade e outros que pautam a convivência dos indivíduos com o aparato estatal. Em média, o governo tem demorado 13 dias para responder aos pedidos, pouco mais de $9 \%$ deles não são respondidos dentro do prazo legal de 20 dias e há prorrogação.

Negativas - O governo negou-se a dar acesso completo a 22.880 pedidos de informação. Desse total, encontram-se 6.771 casos em que foi cedida apenas parte da informação, negando o acesso completo. Em pouco mais de 10 mil solicitações, o governo entendeu que não havia ali um pedido de informação.

Em 8.150 pedidos, o órgão solicitado alegou não ter competência para responder sobre o que lhe foi perguntado. Em 5.216 casos, a entidade pública informou não ter a informação sob seu controle. Percebe-se aqui que há falta de conhecimento da população sobre as reais funções e atividades de determinados órgãos públicos, pois fazem perguntas a instituições que não tratam do assunto. Isso pode indicar uma falha na comunicação desses entes com a sociedade. O que mais gera negativa de resposta é a alegação do órgão público de que a informação pedida é de cunho pessoal, das 22 mil respostas negadas, 8.622 foram justificadas assim. Veja a tabela 1 .

\begin{tabular}{|l|l|l|}
\hline \multicolumn{2}{|c|}{ Motivos de negativas de respostas } \\
\hline Descrição & Quantidade & Porcentagem \\
\hline Dados Pessoais & 8.622 & $37,67 \%$ \\
\hline $\begin{array}{l}\text { Informação sigilosa de acordo } \\
\text { com legislação específica }\end{array}$ & 2.945 & $12,86 \%$ \\
\hline Pedido genérico & 2.843 & $12,42 \%$ \\
\hline Pedido incompreensível & 2.270 & $9,91 \%$ \\
\hline $\begin{array}{l}\text { Pedido desproporcional ou } \\
\text { desarrazoado }\end{array}$ & 1.795 & $7,84 \%$ \\
\hline $\begin{array}{l}\text { Pedido exige tratamento adicional } \\
\text { de dados }\end{array}$ & 1.780 & $7,78 \%$ \\
\hline $\begin{array}{l}\text { Informação sigilosa classificada } \\
\text { conforme a Lei 12.527/2011 }\end{array}$ & 1.604 & $7 \%$ \\
\hline Processo Decisório em curso & 1.026 & $4,48 \%$ \\
\hline Total & 22.885 & $100 \%$ \\
\hline
\end{tabular}

Tabela 1: Motivos de negativas de resposta no SIC.

Fonte: Dados levantados no portal CGU <http://www.cgu.gov.br/>. Acessado em 21 de outubro de 2014.

Nas entrevistas realizadas, foram encontrados operadores que se queixavam da dificuldade em classificar as informações como sigilosas, pois, além da própria Lei 12.527/2011, há outras legislações que tornam dados governamentais secretos e muitos 
operadores da LAI não conhecem essas legislações, daí a dificuldade em aplicar a lei.

Por outro lado, alguns operadores da LAI afirmaram desenvolver um trabalho extra nos casos de pedidos desarrazoados ou que exigiam tratamento da informação. Em alguns casos, esses operadores relatam estabelecer um diálogo com o solicitante para compreender, exatamente, o que ele quer e poder fornecer a informação.

Origem dos pedidos de informação - Ao verificar a origem dos pedidos de informação por Estados (ver Tabela 2), vê-se que o mais populoso da Federação, São Paulo, é responsável por cerca de $25 \%$ dos pedidos. Minas Gerais, com a segunda maior população, fica com cerca de $10 \%$, atrás do Rio de Janeiro, terceiro Estado mais populoso que - apesar da menor população, fez mais pedidos que Minas Gerais - foi responsável por $13 \%$.

A Bahia, com a quarta maior população do Brasil, fez menos pedidos que o Distrito Federal, o Rio Grande do Sul ou Paraná. Em relação ao Distrito Federal, pode-se explicar o alto número de pedidos, pois é a sede da administração pública federal, porém, o fato de os Estados sulistas, mesmo com menor população, superarem a Bahia, pode indicar que o maior desenvolvimento econômico ${ }^{23}$ contribua para isso, ou seja, regiões mais desenvolvidas tendem a usar mais esse serviço público.

Ao verificar quais desses sete Estados fazem mais pedidos, proporcionalmente à sua população, encontra-se o Distrito Federal à frente com larga vantagem, seguido do Rio de Janeiro. Na terceira posição, vem São Paulo. O Rio de Janeiro, por ter sido a capital do País até a década de 1960, tem, ainda, muitos órgãos públicos, inclusive concentra a sede de grandes estatais, como: a Petrobras, o Banco Nacional do Desenvolvimento Econômico e Social (BNDES), Furnas, Eletronuclear, Instituto Brasileiro de Geografia e Estatística (IBGE), dentre outros. Uma hipótese é que esses órgãos ligados ao Estado podem estar na raiz desse maior número de pedidos no Rio de Janeiro. Os demais Estados dessa lista, dos sete que mais fizeram pedidos de informação seguem, de forma razoável, uma linha entre o número de habitantes e a quantidade de pedidos, com a exceção já citada da Bahia.

Educação - Ao observar a escolaridade dos que acessam as informações pôde-se verificar que ocorre uma predominância dos mais escolarizados, mais de 56\% dos que usam o sistema têm, no mínimo, curso superior, entretanto, apenas 7,9\% dos brasileiros têm curso

23

Dados do IBGE apontam que São Paulo tem o maior Produto Interno Bruto (PIB) do Brasil, seguido do Rio de Janeiro. Em terceiro lugar, está Minas Gerais, seguida do Rio Grande do Sul. A Bahia, apesar de ter quarta maior população entre os Estados brasileiros, está na sexta posição quanto ao PIB, ficando atrás, além dos Estados já citados, também do Paraná. Informações sobre o PIB por Estado disponível no site do IBGE em $<\underline{\text { http://www.ibge.gov.br/estadosat/> }}$ 
superior de acordo com dados do Ministério da Educação (Portal MEC). Na outra ponta, é possível observar que pouco mais de $5 \%$ dos que acessam o sistema e pedem informação ao Poder Executivo federal têm, no máximo, o Ensino Fundamental, e os dados do IBGE, de 2010, apontam que mais de 50\% dos brasileiros não têm o Ensino Fundamental completo.

As estatísticas da CGU deixam claras as desigualdades do acesso à informação pública nesses primeiros momentos de implantação e uso da LAI. A grande massa de excluídos do sistema educacional está também excluída do acesso à informação. Essas populações mais vulneráveis são as que mais dependem de políticas públicas e, pelos números vistos aqui, são os que têm menores condições de fiscalizar essas políticas com o uso do acesso à informação.

\begin{tabular}{|c|c|c|c|c|}
\hline $\begin{array}{l}\text { Ranking dos } \\
\text { que fartados } \\
\text { pedidos de informação } \\
\text { pelo e-SIC }\end{array}$ & $\begin{array}{l}\text { População do Estado } \\
\text { (Estimada em milhões } \\
\text { em 2014). }\end{array}$ & $\begin{array}{l}\text { Quantidade de pedidos } \\
\text { de informação por } \\
\text { Estado }\end{array}$ & $\begin{array}{l}\text { Pedido de } \\
\text { informação } \\
\text { por habitante }\end{array}$ & $\begin{array}{l}\text { Estados líderes } \\
\text { considerando } \\
\text { quantidade de } \\
\text { pedidos por } \\
\text { habitante }\end{array}$ \\
\hline $1^{\circ}$ São Paulo & 44.035 .304 & 29.652 (mil) & 0.000673368 & $1^{\circ}$ Distrito Federal \\
\hline $2^{\circ}$ Rio de Janeiro & 16.461 .173 & 15.460 (mil) & 0.000939179 & $2^{\circ}$ Rio de Janeiro \\
\hline $3^{\circ}$ Minas Gerais & 20.734.097 & 11.691 (mil) & 0.000563853 & $3^{\circ}$ São Paulo \\
\hline $4^{\circ}$ Distrito Federal & 2.852 .372 & 9.455 (mil) & 0.003314785 & $\begin{array}{l}4^{\circ} \text { Rio Grande do } \\
\text { Sul }\end{array}$ \\
\hline $5^{\circ}$ Rio Grande do Sul & 11.207.274 & 7.000 (mil) & 0.000624594 & $5^{\circ}$ Minas Gerais \\
\hline $6^{\circ}$ Paraná & 11.081 .692 & 5.699 (mil) & 0.000514271 & $6^{\circ}$ Paraná \\
\hline $7^{\circ}$ Bahia & 15.126 .371 & 5.354 (mil) & 0.000353951 & $7^{\circ}$ Bahia \\
\hline
\end{tabular}

Tabela 2: Dados dos Estados que mais fazem pedidos de informação no e-SIC.

Fonte: Dados retirados do site da CGU <http://www.cgu.gov.br/> e do IBGE <http://www.ibge.gov.br/home/>. Acessados em 21 de outubro e 15 de dezembro de 2014, respectivamente.

Mendel (2009), ao relatar a experiência da implantação da lei de acesso à informação na Índia, cita o caso de uma mulher inscrita em um programa de acesso à moradia subsidiada pelo governo e que não conseguia ser atendida. Utilizando-se da lei de acesso à informação ela pôde descobrir porque seu processo não andava e encontrar a solução para o problema, sendo atendida pelo programa de moradia popular. Esse exemplo deixa claro o tamanho do desafio que a LAI brasileira enfrentará para conseguir que os usuários que mais necessitam das políticas estatais tenham sobre elas algum tipo de controle, do contrário, a nova legislação tende a repetir as desigualdades sociais históricas enfrentadas no País.

Ainda nessa questão da dificuldade de determinados grupos acessarem informações públicas, cita-se o caso da Suécia que, segundo Wallin (2014), tem um sistema de acesso que 
atende a especificidades de pessoas com dificuldades de fala ou para escrever com um funcionário público intermediando as conversas e fazendo anotações auxiliando o cidadão que tenha dificuldades. Assim, a falta de uma educação formal ou uma deficiência física não impede o direito de acesso à informação pública.

A Declaração de Atlanta ${ }^{24}$ trata a questão das dificuldades de acesso a informações públicas por parte das populações mais pobres. Diz o documento: "a falta de acesso à informação afeta desproporcionalmente os pobres, as mulheres e outras comunidades vulneráveis e marginalizadas...”.

24 A Declaração de Atlanta é um documento internacional elaborado em 2008 na cidade de Atlanta, Estados Unidos, e que é considerado, pela Associação Brasileira de Jornalismo Investigativo (Abraji) como um dos documentos mais completos sobre acesso à informação no mundo. $\mathrm{O}$ documento está disponível em $<$ http://www.cartercenter.org/resources/pdfs/peace/americas/atlanta_declaration_unofficial_portuguese.pdf $>$. Já a posição da Abraji sobre a Declaração pode ser vista em $<$ http://abraji.org.br/?id=90\&id_noticia=620 $>$. Ambos acessados em 15 de fevereiro de 2015. 


\section{Caminhos metodológicos}

\subsection{Objetivos}

Objetivo geral:

Analisar o processo de implementação da Lei de Acesso à Informação nos Institutos Federais de Educação, Ciência e Tecnologia (IF's).

\section{Objetivos específicos}

1. Analisar como está sendo construída a transparência ativa nos IF's a partir da implantação da LAI;

2. Analisar a relação entre os setores de comunicação e da LAI nos IF's;

3. Analisar como os operadores da comunicação nos IF's veem a LAI;

4. Analisar como os operadores da LAI avaliam o processo de implantação da Lei;

5. Analisar como os operadores da LAI avaliam a relação com o setor de comunicação nos IF's;

6. Contribuir para a ampliação do conhecimento sobre a comunicação no setor público.

\subsection{O problema de pesquisa}

Seguindo a recomendação de Gil (2010), expõe-se o problema em forma de pergunta: como está ocorrendo a implementação da Lei de Acesso à Informação nos Institutos Federais de Educação, Ciência e Tecnologia e de que forma estão se relacionando os setores da LAI e da comunicação nessas instituições?

Geraldes e Sousa (2013) afirmam que o Estado deve ser, não apenas informativo, mas também comunicativo. Nessa mesma linha de pensamento, Mendel (2009) diz que o acesso à informação é uma forma de desenvolvimento pela comunicação. Ainda, segundo o mesmo autor, mais que garantir um direito, o livre acesso à informação permite que a população fiscalize a execução de políticas públicas e controle as ações dos agentes governamentais.

Para explicar melhor o problema, é necessário estabelecer a diferença entre informação e comunicação. Wolton (2006) afirma que a informação é ligada à mensagem. Informar é produzir e distribuir mensagens. Por outro lado, a comunicação pressupõe um processo mais complexo em que o receptor é tratado de forma a ser entendido, procura-se analisar o que ele faz com a mensagem. Enquanto informar é enviar ou disponibilizar a 
mensagem, comunicar é interagir, a comunicação é dialógica (WOLTON, 2006). Martino 25 afirma que informação é a mensagem que está em um determinado objeto; como exemplo, ele cita desenhos rupestres em uma caverna. Quando essa informação interage com uma consciência, ocorre a comunicação.

Este trabalho tem início na informação, conforme conceituado por Wolton e Martino. Foram realizadas algumas pesquisas para verificar se os dados dos IF's estão disponíveis ao público de forma adequada por meio de seus sites. Portanto, comecei o trabalho verificando apenas as informações. Entretanto, o fundamento que sustentou a pesquisa se constituiu por meio de análise das informações obtidas junto aos chamados operadores da LAI e da comunicação, de modo a verificar, por meio de suas manifestações, como os institutos, a partir da implantação da LAI, estão se comunicando ou pretendem estabelecer estratégias para se comunicarem com seus públicos-alvo. O centro da pesquisa foi a comunicação, apesar de, para chegar até ela, ter sido necessário passar pela informação.

\subsection{Justificativa}

Plano social - A sociedade brasileira, como dito por Jardim (1999), organiza-se sobre o segredo. O secretismo, no Brasil, coloca-se desde a violência doméstica que é silenciada pelo machismo até as ações de autoridades públicas que tratam informações de todos como se fossem suas.

Compreender essa situação, jogar luz sobre como funciona, como se justifica socialmente, pode levar à reflexão sobre o tema. A imprensa, as relações-públicas, a publicidade, enfim, tudo o que envolve a comunicação, tem, em tese, a função de combater o secretismo. Porém, isso muitas vezes não ocorre. Daí a necessidade de se entender tais situações e refletir sobre elas.

Plano acadêmico - A produção científica, na área da comunicação, a respeito de leis de 26 acesso à informação ainda é pequena no Brasil , o que pode ser entendido com certa

25 Conceitos de comunicação e informação apresentados pelo professor Luiz Cláudio Martino em aula de Teorias da Comunicação ministrada em 28 de maio de 2013 no Programa de Pós-graduação em Comunicação da UnB.

26 Todos os trabalhos produzidos na área de comunicação em relação à LAI, encontrados por esta pesquisa foram: as dissertações de mestrado de Reis (2014) e Dutra (2015) e artigos publicados nos anais da Associação Brasileira de Pesquisadores em Jornalismo (SBPJor), dois artigos, Paulino e Silva (2012) e Gentilli e Dutra (2012); também levantou-se as publicações no Portcom da Sociedade Brasileira de Estudos Interdisciplinares da Comunicação (Intercom), nove artigos foram encontrados, Mesquita (2014a), Mesquita (2014b), Geraldes e Reis 
naturalidade, visto que aqui tal legislação não existia até 2012.

A primeira pesquisa encontrada durante a realização deste trabalho é a de Paulino e Silva (2012) que utilizaram entrevistas realizadas por telefone para coletar dados sobre as políticas de aplicação da LAI. O objetivo do trabalho deles foi verificar como os serviços relacionados à LAI estão estruturados. Foram coletados dados de 48 universidades federais em um universo de 59 instituições. Observou-se que, em 75\% dessas universidades, o Sistema de Acesso à Informação está vinculado à Ouvidoria e os demais $25 \%$ estão vinculados ao gabinete do reitor. Tal informação tem grande validade para este trabalho, pois aponta como a lei está funcionando em instituições muito semelhantes às que se pesquisou aqui.

Tem-se também Gentilli e Dutra (2012) que apresentam o resultado de uma pesquisa sobre as políticas de implementação da LAI na qual concluíram não haver relação entre os setores de aplicação da lei e os de comunicação. Nessa pesquisa, foram analisadas as políticas de implementação da LAI nas 27 unidades da Federação, com maior ênfase em seis. Foi realizada nos sites dos governos estaduais e do Distrito Federal (DF). Gentilli e Dutra encontraram, nos Estados e no DF, estruturas específicas para dar formato à transparência ativa, e elas não incluíam os setores de comunicação. Aqui se tem, como informação útil para a presente pesquisa, essa separação entre a LAI e a comunicação.

Portanto, a justificativa acadêmica para este trabalho é o fato de haver pouca produção sobre um tema que está impactando estruturas tão grandes como são as do Estado brasileiro e a necessidade de se produzir reflexão inicial e continuada sobre um tema com relevância e importância para a cidadania e para o estabelecimento de uma nova cultura de ação pública. Este trabalho, com o passar do tempo, poderá compor um conjunto de pesquisas que permitirão entender o processo de implantação da LAI em sua completude.

\subsection{Delimitando o objeto de pesquisa}

O objeto desta pesquisa é o processo de implementação da LAI nos Institutos Federais de Educação, Ciência e Tecnologia. Dentro desse objeto, duas nuances interessam de forma mais específica: a relação da LAI com a comunicação e a constituição da transparência ativa que é aquela em que o Estado disponibiliza informação de forma proativa.

A Lei de Acesso à Informação estabelece que os órgãos públicos devem usar de todos os instrumentos legítimos que tiverem para implementar a transparência ativa, sendo que são 
obrigatórios a criação e manutenção de sites na Rede Mundial de Computadores para todas as instituições públicas, excluídas aquelas de municípios com até 10 mil habitantes.

Tendo a LAI feito essa exigência do uso da internet, começou-se a aproximação ao objeto por aí: fazendo o primeiro contato com o estabelecimento da transparência ativa dos IF's a partir de como estão elaborados os seus sites na Rede Mundial de Computadores.

\subsubsection{Lócus}

De acordo com a Lei 12.527/2011, a aplicação da LAI pode dar-se em:

I - [...] órgãos públicos integrantes da administração direta dos Poderes Executivo, Legislativo, incluindo as Cortes de Contas, e Judiciário e do Ministério Público; II - as autarquias, as fundações públicas, as empresas públicas, as sociedades de economia mista e demais entidades controladas direta ou indiretamente pela União, Estados, Distrito Federal e Municípios. (LEI 12.527 DE 18 DE NOVEMBRO DE 2011, ART.1 ${ }^{\circ}$, PARÁGRAFO ÚNICO, INCISOS I E II).

Ou, ainda, nas:

entidades privadas sem fins lucrativos que recebam, para realização de ações de interesse público, recursos públicos diretamente do orçamento ou mediante subvenções sociais, contrato de gestão, termo de parceria, convênios, acordo, ajustes ou outros instrumentos congêneres. (LEI 12.527 DE 18 DE NOVEMBRO DE 2011, ART. $\left.2^{\circ}\right)$.

Como exposto acima, a LAI não é aplicada apenas em órgãos ou empresas públicas. Essa situação faz com que os locais onde se pode observar a lei se tornem demasiadamente amplos. Aqui se fez a escolha pela administração pública, pois a CGU saiu na frente na implementação da $\mathrm{LAI}^{27}$, ofertando cursos de capacitação para os servidores públicos, disponibilizando material gráfico de conscientização e normatizando a nova legislação.

Dentro dessa grande estrutura denominada administração pública federal do Poder Executivo, opta-se por estudar a área de educação, especificamente um conjunto de autarquias que compõem uma rede de ensino, a Rede Federal de Educação, Ciência e Tecnologia que está ligada ao Ministério da Educação (MEC).

A Rede Federal de Educação, Ciência e Tecnologia é um conjunto de instituições que oferta ensino profissional, técnico e superior ${ }^{28}$, além de realizar Pesquisa e Extensão. Essa

27 Em curso de formação sobre a implantação da LAI, ofertado pela CGU em 2012, representantes do poder Legislativo federal informaram ainda não terem regulamentado a Lei. No caso do Judiciário, houve polêmica na imprensa sobre a aplicação da LAI, e, consequentemente, atrasos na implementação.

28 1. Ensino profissional: capacitações de curta duração, vendedor, por exemplo, com carga horária de 
rede totaliza, de acordo com dados do Portal do Ministério da Educação, mais de 400 campi e está em expansão $^{29}$. Além de haver todas essas unidades e ocorrer uma expansão, a escolha justifica-se, pois os IF's são semelhantes às universidades que têm autonomia administrativa, financeira e didático-pedagógica; ou seja, o que se verificar nesse espaço poderá ser inferido para uma grande quantidade de outros órgãos públicos, como as universidades federais, estaduais ou municipais, além das escolas técnicas federais, estaduais ou municipais.

Essa Rede tem instituições centenárias, criadas em 1909 para atender às populações mais pobres das cidades brasileiras. A ideia original era capacitar os filhos dos que não dispunham de recursos financeiros, de modo que se ajudasse a conter o avanço da marginalidade.

O nome original dos Institutos Federais era Escola de Aprendizes e Artífices que ofertava cursos profissionalizantes. Essas instituições evoluíram durante as décadas de 1950 e 1960 e se transformaram em Escolas Técnicas Federais; nas décadas de 1980 e 1990, muitas viraram Centros Federais de Educação Tecnológica (Cefet's). Ao longo desse processo, modernizaram-se com o País, passaram a ofertar cursos superiores e cresceram. Assim como as profissões técnicas ganharam importância com a industrialização, o ensino técnico também se fortaleceu. Em 2008, o governo do presidente Luiz Inácio Lula da Silva transformou os Cefet's, as Escolas Técnicas Federais que restavam e várias Escolas Agrotécnicas ou Técnicas vinculadas a universidades federais em Institutos Federais de Educação, Ciência e Tecnologia (IF's) e equiparou, legalmente, essas instituições às universidades com autonomia administrativa, financeira e didático-pedagógica.

Atualmente, são 38 Institutos Federais, uma Universidade Tecnológica, o Colégio Pedro II, o Cefet-RJ e o Cefet-MG, perfazendo um total de 42 instituições que formam a Rede Federal de Educação, Ciência e Tecnologia definida na Lei 11.892 de 2008.

Com a criação dos IF's, iniciou-se uma expansão do número de unidades, agora denominadas campus. Essa mudança mexeu com a cultura das instituições, mas sua missão original manteve-se: capacitar trabalhadores.

$160 \mathrm{~h} ;$

2. Ensino Técnico: de nível médio, por exemplo, Técnico em Segurança do Trabalho. Os Institutos oferecem cursos técnicos concomitantes ao Ensino Médio, ou seja, os alunos cursam disciplinas técnicas nos IF's e as demais em outra instituição; há também os técnicos subsequentes em que o estudante que já concluiu o Ensino Médio se matricula em um IF para fazer exclusivamente disciplinas técnicas. Por fim, existe a modalidade integrado quando o IF oferta o Ensino Médio regular integrado ao curso técnico.

3. Ensino Superior: os Institutos oferecem graduações com cursos, preferencialmente, tecnológicos, licenciaturas e engenharias;

4. Pós-graduação lato e stricto sensu, tanto mestrados quanto doutorados, preferencialmente nas ciências que gerem, de forma direta, inovação tecnológica.

29 Este número de Campi é de 2010, não há, no site do MEC dados atualizados. 
Fazendo analogia com o Decreto presidencial de 1909 que criou as Escolas de Aprendizes e Artífices para atender aos "filhos dos desfavorecidos da fortuna" (Decreto $\mathrm{n}^{\circ}$ 7.566/1909), os IF's continuam com o objetivo de atender aos trabalhadores, e seus programas são voltados primordialmente, para a capacitação técnica e, agora, para o desenvolvimento da ciência ${ }^{30}$.

O novo desenho institucional, criado em 2008, ainda enfrenta resistências em sua implantação, prova disso são o Cefet-RJ e Cefet-MG que se mantêm com seus nomes e estruturas anteriores a 2008, recusando-se a aderir por completo à Rede. As escolas técnicas e os Cefet's não foram obrigados a se inserir na nova estrutura como Institutos Federais. A adesão ao novo modelo foi voluntária.

\subsubsection{O corpus da pesquisa}

Como parte do processo de aproximação do objeto de pesquisa, realizou-se, inicialmente, uma análise de conteúdo nos sites de 41 instituições que compõem a Rede Federal para verificar quais cumpriam melhor as determinações da Lei de Acesso à Informação. Os critérios usados para analisar os sites são os definidos no parágrafo $1^{\circ}$ do Art. $8^{\circ}$ da LAI. Neste tópico é estabelecido o conjunto de informações que devem, necessariamente, estar presentes nos sites de instituições públicas, a saber:

\footnotetext{
I - registro das competências e estrutura organizacional, endereços e telefones das respectivas unidades e horários de atendimento ao público;

II - registros de quaisquer repasses ou transferências de recursos financeiros;

III - registros das despesas;

IV - informações concernentes a procedimentos licitatórios, inclusive os respectivos editais e resultados, bem como a todos os contratos celebrados;

$\mathrm{V}$ - dados gerais para o acompanhamento de programas, ações, projetos e obras de órgãos e entidades; e

VI - respostas a perguntas mais frequentes da sociedade. (LEI 12.527, DE 18 DE NOVEMBRO DE 2011, ART. $8^{\circ}$, PARÁGRAFO $1^{\circ}$ ).
}

Após examinar o universo composto pelos sites dos 41 institutos federais, chegou-se a uma lista com essas instituições citadas de forma ordenada onde os que melhor atendem ao Parágrafo $1^{\circ}$, do Artigo $8^{\circ}$, estão nas primeiras colocações, e os que nada atendem, nas últimas posições. Foi possível estabelecer uma nota em percentual para cada um dos institutos, de acordo com o atendimento ou não das determinações da LAI, conforme segue na Tabela 3.

30 Informações retiradas do site do Instituto Federal de Goiás < $<$ www.ifg.edu.br $>$ e do Decreto Presidencial $\mathrm{N}^{\mathrm{o}}$ 7566 de 23 de setembro de 1909. Acessado durante o mês de setembro de 2013. 


\begin{tabular}{|c|c|c|}
\hline Posição & Instituição & Nota \\
\hline \multirow[t]{11}{*}{$1^{\mathrm{a}}$ posição } & IFCE & $100 \%$ \\
\hline & IFES & $100 \%$ \\
\hline & IF Farroupilha & $100 \%$ \\
\hline & IFGO & $100 \%$ \\
\hline & IFMG & $100 \%$ \\
\hline & IFRN & $100 \%$ \\
\hline & IFRS & $100 \%$ \\
\hline & IFSC & $100 \%$ \\
\hline & IFSP & $100 \%$ \\
\hline & IF Sul Rio Grandense & $100 \%$ \\
\hline & UTFPR & $100 \%$ \\
\hline \multirow[t]{8}{*}{$2^{\mathrm{a}}$ posição } & Col. Pedro II & $83 \%$ \\
\hline & IF Baiano & $83 \%$ \\
\hline & IF Goiano & $83 \%$ \\
\hline & IFMS & $83 \%$ \\
\hline & IFPR & $83 \%$ \\
\hline & IFRJ & $83 \%$ \\
\hline & IF Sertão & $83 \%$ \\
\hline & IFTO & $83 \%$ \\
\hline \multirow[t]{8}{*}{$3^{\mathrm{a}}$ posição } & Cefet-MG & $67 \%$ \\
\hline & Cefet-RJ & $67 \%$ \\
\hline & IFNMG & $67 \%$ \\
\hline & IFPE & $67 \%$ \\
\hline & IFRR & $67 \%$ \\
\hline & IF Sudeste de MG & $67 \%$ \\
\hline & IF Sul de MG & $67 \%$ \\
\hline & IFTM & $67 \%$ \\
\hline $4^{\mathrm{a}}$ posição & IFMT & $50 \%$ \\
\hline \multirow[t]{5}{*}{$5^{\mathrm{a}}$ posição } & IFAM & $17 \%$ \\
\hline & IFBA & $17 \%$ \\
\hline & IFF & $17 \%$ \\
\hline & IFMA & $17 \%$ \\
\hline & IFPI & $17 \%$ \\
\hline \multirow[t]{6}{*}{$6^{\mathrm{a}}$ posição } & IFAC & $0 \%$ \\
\hline & IFAL & $0 \%$ \\
\hline & IFAP & $0 \%$ \\
\hline & IFC & $0 \%$ \\
\hline & IFPA & $0 \%$ \\
\hline & IFPB & $0 \%$ \\
\hline
\end{tabular}




\begin{tabular}{|l|l|} 
IFRO & $0 \%$ \\
\hline IFS & $0 \%$ \\
\hline
\end{tabular}

Tabela 3: Lista com notas aos IF's conforme atendimento aos critérios da LAI.

Fonte: Dados levantados pelo autor da pesquisa junto aos sites dos IF's.

Na ponta de cima da escala, estão os IF's melhor avaliados. A partir dessa tabela, o corpus da pesquisa foi formado, pois buscou-se entrevistar os operadores da LAI e da comunicação dos Institutos que melhor cumprem a lei. Optou-se por entrar em contato com os primeiros colocados dessa lista, visto que seus institutos produziram mais conteúdo para a LAI. Quando os procurados recusavam-se a dar entrevistas, seguia-se para o próximo da lista. Dessa forma, o corpus da pesquisa foi estabelecido a partir do conjunto de falas obtidas de entrevistados e operadores da LAI e da comunicação das seguintes instituições:

- Instituto Federal do Ceará (IFCE);

- Instituto Federal do Rio Grande do Norte (IFRN);

- Instituto Federal de Goiás (IFGO);

- Instituto Federal de Minas Gerais (IFMG);

- Instituto Federal do Espírito Santo (IFES);

- Instituto Federal de São Paulo (IFSP);

- Universidade Tecnológica Federal do Paraná (UTFPR);

- Instituto Federal de Santa Catarina (IFSC);

- Instituto Federal Sul-Rio-grandense (IFSul);

- Instituto Federal do Rio Grande do Sul (IFRS);

- Instituto Federal Farroupilha (IF Farroupilha);

- Instituto Federal do Tocantins (IFTO);

- Instituto Federal Goiano (IF Goiano);

- Instituto Federal do Mato Grosso do Sul (IFMS);

- Instituto Federal do Piauí (IFPI);

- Colégio Pedro II;

- Instituto Federal do Norte de Minas Gerais (IFNMG);

\subsection{Métodos e técnicas utilizados na pesquisa}

\subsubsection{Análise de conteúdo}

A metodologia norteadora desta pesquisa foi a Análise de Conteúdo, seja aplicada enquanto método geral de tratamento das informações e como técnica de pesquisa aplicada 
aos sites dos IF's ou nas entrevistas dos operadores da LAI e da comunicação.

Júnior (2011) afirma que a Análise de Conteúdo se ocupa basicamente com a análise de mensagens, categorizando-as e fazendo análises das categorias separadas, relacionando-as com outros pontos ligados ao tema pesquisado.

Essa metodologia foi utilizada nas ciências políticas para a descoberta de armas secretas alemãs pelos britânicos, a partir da propaganda nazista; na psicologia, contribuiu para o diagnóstico de pacientes por meio da análise da gravação de entrevistas terapêuticas; na crítica literária, permitiu destacar os traços característicos do estilo de um autor; na sociologia, a compreender a diversidade das mentalidades nacionais; na comunicação de massa, a comparar as atitudes adotadas por diferentes jornais em período eleitoral (KIENTZ apud JÚNIOR, 2011).

Aqui, serviu para entender como está o processo de implantação da LAI olhando para os sites dos IF's e para os posicionamentos expressados verbalmente pelos operadores da lei e da comunicação.

\subsubsection{Entrevistas}

$\mathrm{Na}$ utilização das entrevistas, foram usados os modelos em profundidade e semiabertas. De acordo com Duarte (2011), a entrevista em profundidade possibilita identificar problemas, microinterações, padrões e detalhes, obter juízos de valor e interpretações. Já a semiaberta é aquela que tem origem em uma matriz, um roteiro de questões-guia que dão cobertura ao interesse da pesquisa.

Para conseguir elaborar os roteiros que foram utilizados nas entrevistas, optou-se por realizar conversas prévias com os operadores da LAI na amostra dos 11 IF's mais bem colocados na análise dos sites, conforme se pode observar na Tabela 3. Essas conversas, chamadas aqui de prospectivas, serviram para:

- Testar meios técnicos mais adequados para suas realizações definitivas, se por Skype, telefone com escuta, telefone fazendo apenas anotações, Gtalk ou e-mail;

- Verificar como estaria o consentimento dos operadores da LAI que estavam dispostos a participar do projeto de pesquisa ao longo de sua realização;

- Obter informações que ajudassem na construção do objeto;

- Ter uma compreensão inicial do que estava ocorrendo nesses IF's.

Foram entrevistados, nessa rodada de conversas, representantes de 11 IF's, um de cada instituição. Em todos os casos, eles tiveram a garantia de que não seriam identificados nos textos. Essa garantia objetivou dar maior certeza de que os servidores públicos não se 
sentiriam intimidados em expor a realidade.

Depois dessa conversa inicial, foram realizadas entrevistas pessoalmente, com deslocamento deste pesquisador até os entrevistados. Essa decisão se deu porque os operadores da LAI e da Comunicação não tinham instalado em seus computadores, nos locais de trabalho, o Skype e havia todo um procedimento burocrático para que a instituição autorizasse tal instalação. As gravações não atendiam às necessidades da pesquisa, visto que os aparelhos gravadores de voz via telefone, que não são profissionais, têm qualidade ruim.

As conversas prospectivas permitiram também que se organizassem os roteiros para a realização das entrevistas semiabertas. Foram elaborados três modelos diferentes: um para os operadores da LAI e um para os operadores da comunicação que contava com uma subdivisão, no caso de o operador ser também gestor da comunicação no instituto, havia mais perguntas.

Iniciaram-se as entrevistas presencialmente, porém, apesar de se ter agendado as visitas aos institutos com até 30 dias de antecedência, alguns entrevistados cancelavam as conversas quando já se havia feito a viagem até suas respectivas cidades. Nesse contexto, apenas dois institutos foram visitados e oito entrevistas realizadas presencialmente, então, foram canceladas as demais viagens agendadas, optando-se por dar continuidade às entrevistas via telefone, realizando gravações ou anotações mesmo enfrentando as dificuldades técnicas já citadas. Com essa medida, evitou-se o desgaste dos cancelamentos e a realização da pesquisa foi agilizada. Foram entrevistados 13 operadores da LAI e 19 operadores da comunicação, sendo 13 gestores, 1 publicitário, 1 diagramador, 1 gestor de comunicação de campus e 3 jornalistas. No total, foram 32 entrevistados entre operadores da LAI e da comunicação.

Entende-se, aqui, por operadores da LAI, os servidores que trabalham com a lei de forma direta, ou seja, que têm entre suas atribuições executar as ações da LAI, recebendo pedidos de informação, postando informações no site, enviando informações para serem postadas no site, fiscalizando o bom funcionamento da lei. $\mathrm{O}$ termo se aplica apenas àquelas pessoas que receberam formalmente essa atribuição por meio de qualquer documento interno da instituição, seja nomeação para tal cargo ou um documento que, apesar de não atribuir tal cargo ao servidor, dê-lhe tais atribuições como agente da LAI. Assim, pode-se exemplificar que um servidor nomeado para ser a autoridade de monitoramento da LAI é um operador; um servidor a quem se atribui a atividade de acessar o sistema eletrônico e-SIC e administrar as demandas lá presentes é um operador; um servidor nomeado para administrar os pedidos de 
informação em uma diretoria, departamento, pró-reitoria ou equivalente, é um operador. Entretanto, um servidor da Tecnologia da Informação ou da Comunicação que receba ordens para postar informações no site não é um operador da LAI, ele executa tais tarefas como obrigações 'naturais' da sua profissão, da sua função técnica dentro da instituição. Nesse contexto, ele apenas responde a uma demanda feita pelo operador da LAI, assim como atenderia a demanda de qualquer outro servidor da instituição, seu compromisso não é especificamente com a lei, com o seu bom funcionamento, mas com a instituição de modo geral. Portanto, operador da LAI é o servidor que atua para o funcionamento da lei, pois essa é sua atividade-fim e não apenas atividade-meio.

Operador da comunicação é todo servidor ou funcionário que realize atividades técnicas de comunicação como parte de suas atribuições funcionais.

O período de realização das entrevistas deste trabalho é de agosto a outubro de 2014. Esse modelo de pesquisa, em que se analisa um ato no momento em que ele ainda acontece, é chamado por Flick (2009, p. 135-136) de Instantâneo e trata de "uma pesquisa (que) não visa primariamente à reconstrução retrospectiva de um processo. Em vez disso, a pesquisa trata de fornecer uma descrição de circunstâncias no momento da pesquisa".

\subsection{Categorias de análise das entrevistas}

Feitas as entrevistas definitivas, partiu-se para as análises do material coletado. Os entrevistados foram divididos em dois grupos: operadores da LAI e operadores da comunicação. Para cada um desses grupos de entrevistados, estabeleceram-se sete categorias, como segue:

\subsubsection{Categorias para analisar as entrevistas dos operadores da LAI:}

1. Categoria 1: Visão dos operadores da LAI sobre a Lei;

2. Categoria 2: Estrutura de implantação da LAI;

3. Categoria 3: Visão dos operadores da LAI sobre a comunicação;

4. Categoria 4: Similaridades entre as funções da LAI e da Comunicação;

5. Categoria 5: Visão da transparência ativa;

6. Categoria 6: Perfil profissional dos operadores da LAI;

7. Categoria 7: Relações entre o operador e o usuário da informação.

\subsubsection{Categorias para analisar as entrevistas dos operadores da comunicação:}


1. Categoria 1: Nível de conhecimento da LAI;

2. Categoria 2: Proximidades entre a visão dos operadores da comunicação e as normas da LAI;

3. Categoria 3: Visão dos operadores da Comunicação sobre a LAI;

4. Categoria 4: Avaliação da relação entre a LAI e a Comunicação;

5. Categoria 5: Mudanças influenciadas pela LAI;

6. Categoria 6: Visão dos operadores da Comunicação sobre a transparência ativa;

7. Categoria 7: Estrutura física e de pessoal da comunicação. 


\title{
3. Conceito teórico que dialoga com a pesquisa: Comunicação Pública
}

Mesmo verificando que há poucas pesquisas científicas a respeito da Lei de Acesso à Informação relacionando-a ao campo da comunicação, seria ingênuo imaginar que não existe teoria ou produção científica já de grande monta que possa explicar ou ao menos contextualizar muitos dos aspectos da Lei de Acesso à Informação e suas relações com a comunicação.

Flick (2009), ao comentar sobre a relação da teoria com o objeto pesquisado, cita como exemplo o pesquisador que coloque o foco de sua pesquisa na classe média. Para ele, esse trabalho provavelmente já parte das noções de classe e de desigualdade social. Da mesma forma, se há uma decisão por pesquisar as mulheres, o cientista parte de ideias como a diferença de gêneros. Portanto, ao escolher o conceito teórico que vai servir de lente para observar a LAI, muitas premissas já se estabelecem.

Tem-se como base teórica para este trabalho o conceito de Comunicação Pública. Entende-se, aqui, que o conhecimento produzido nesta área, especialmente na literatura francesa, consegue abordar muitas das questões desta pesquisa e contribui para explicar seu objeto, o processo de implantação da LAI nos IF's.

Há, na literatura brasileira , uma dificuldade no momento de definir esse conceito. Afirma-se que abarca a iniciativa privada, a pública, as duas; diz-se que se trata de uma forma de comunicação organizacional; ou, que comunicação pública é a radiodifusão não comercial e se seguem outras definiçõos.

Brandão (2009) afirma que:

\begin{abstract}
A expressão comunicação pública (CP) vem sendo usada com múltiplos significados, frequentemente conflitantes, dependendo do país, do autor e do contexto em que é utilizada. Tamanha diversidade demonstra que a expressão ainda não é um conceito claro, nem mesmo uma área de atuação profissional delimitada. (BRANDÃO, 2009, p. 1).
\end{abstract}

Haswani (2011) diz que a Comunicação Pública remete ao Estado, mas compreende processos diversos e faz interagir os atores públicos e privados numa perspectiva de ativar a

31 Curtinovi e Mesquita (2014) realizaram um levantamento histórico a respeito do termo "Comunicação Pública" no Grupo de Pesquisa Políticas e Estratégias de Comunicação da Sociedade Brasileiras de Estudos Interdisciplinares de Comunicação (Intercom) no qual apontaram haver essa dificuldade na definição e uso do termo na literatura de comunicação brasileira. 
relação entre o Estado e os cidadãos com o intuito de promover um processo de crescimento civil e social. Essa autora entende que, inicialmente, quando começaram os debates sobre a Comunicação Pública, ela estava ligada inteiramente ao Estado, mas a diminuição do poder estatal, com o avanço do neoliberalismo, alterou essa relação.

O Estado, diz Haswani, abriu mão de grande parte de suas responsabilidades e as entregou para entidades que podem ser denominadas semipúblicas. Essas instituições não compreendem exatamente a iniciativa privada, nem a pública, mas um terceiro setor que visa ao interesse público e não busca lucro.

Além do terceiro setor, empresas privadas também assumiram responsabilidades que seriam, antes, do Estado, como assistência social às populações mais pobres ou apoio a grupos socialmente vulneráveis. Muitos desses serviços que eram vistos como estatais, passaram a ser tratados como responsabilidade social de empresas que os assumiam, em tese, sem visar ao lucro. Diz-se em tese, porque essas entidades privadas também podem usar tais políticas de responsabilidade social como instrumento de propaganda institucional que visa a melhorar sua imagem e pode levar a melhores lucros. Os movimentos de luta por direitos da comunidade LGBT e combate à Aids podem ser usados como exemplo dessa retirada de responsabilidade do poder público e transferência para instituições semipúblicas. Organizações Sociais, administradas pela militância LGBT, executam ações de combate à Aids a partir de financiamento vindo dos setores de responsabilidade social de empresas privadas que financiam projetos denominados sociais. Nesse exemplo, tanto o financiamento quanto a execução da política pública estaria sob responsabilidade privada, entretanto, esses papéis se cruzam e pode ocorrer de o poder público financiar, e organizações semipúblicas executarem ou a iniciativa privada financiar a ação e um órgão do Estado a executar.

O que importa dessa mudança, trazida pelo neoliberalismo e citada por Haswani (2011), é que a Comunicação Pública vista antes como uma questão estatal, teve suas definições alteradas por essa nova realidade com fronteiras mais confusas entre o estatal e o privado.

Para Weber (2011, p. 105), os sistemas, as redes e as assessorias de comunicação dos poderes Executivo, Legislativo ou Judiciário "comunicam a defesa direta dos poderes políticos de quem está no poder". Ela vê a Comunicação Pública de forma semelhante à de muitos dos entrevistados para esta pesquisa, ou seja, funcionaria para justificar os atos das instituições contribuindo para a manutenção de uma imagem positiva de quem está no poder. 
Entretanto, apesar desse posicionamento, Weber (2011, p. 106) ressalta que essa situação "não significa dizer que a ética ou a verdade estejam sendo burladas".

A autora trata de algo essencial na manutenção de um sistema de Comunicação Pública, a burocracia estatal. Esta pesquisa buscou entender como funcionam os sistemas burocráticos da comunicação 32 e da LAI na Rede Federal de Educação, Ciência e Tecnologia. Weber diz que o quadro de profissionais desse sistema burocrático e sua qualificação permitem concluir que a Comunicação Pública por eles produzida tem condições de competir com as mídias de massa na definição das versões sobre a realidade.

Entretanto, compreende-se que esse sistema burocrático só pode competir com o sistema midiático quando, além da estrutura física com veículos, recursos e meios de difusão, existir também certo grau de autonomia desses profissionais em relação ao poder político estabelecido. É necessário que questões técnicas e éticas básicas para a produção de informações independam do poder político governante em cada momento. Dessa forma, seria possível garantir que essas estruturas de comunicação não percam sua credibilidade.

Diante da indefinição encontrada na literatura quanto ao conceito de Comunicação Pública e tendo por base a LAI, estabeleceu-se neste trabalho uma ideia própria desse termo, como sendo aquela praticada pelo Estado por meio da administração direta de canais de radiodifusão, por meio de assessorias de comunicação e por qualquer comunicação social praticada pelo Estado direta ou indiretamente, ou por ele financiada.

Os porquês dessa definição encontram-se na LAI que trata como informação pública aquela que esteja sob controle do Estado de forma direta ou indireta, por meio de suas empresas ou de instituições privadas sem fins lucrativos que tratem com recursos públicos, na parte exclusiva desses recursos. Isso significa que, se uma instituição privada recebe dinheiro do orçamento estatal, as prestações de contas desse dinheiro são de natureza pública. Portanto, uma ONG que receba valores vindos dos cofres do Estado, quando for fazer qualquer ação de comunicação usando esses recursos, terá que utilizar a Comunicação Pública.

Isso significa que as assessorias de comunicação de instituições estatais, que são também alvos desta pesquisa, praticam Comunicação Pública. Com essa definição, consegue-

32 De acordo com Chiavenato (2013, p. 106) constituem-se como principais orientadores do modelo de administração burocrático do Estado: a profissionalização, a ideia de carreira, a hierarquia funcional, a impessoalidade e o formalismo. Entende-se, aqui, como sistemas burocráticos de comunicação os servidores públicos que executam as ações de comunicação, as regras que regem esse trabalho e as estruturas físicas como espaços e equipamentos que servem às ações de comunicação. 
se abarcar todo o escopo de instituições que a LAI estabelece como obrigadas a prestar informações à sociedade.

Definiu-se, acima, a abrangência da Comunicação Pública, mas não as suas características. Isso será feito nas próximas páginas que estão baseadas no pensamento do autor francês Pierre Zémor.

\subsection{LAI e Comunicação Pública}

Entende-se aqui que, para pôr em prática a Lei de Acesso à Informação, a ideia da Comunicação Pública precisa estar presente nos setores de comunicação das instituições que compõem a Rede Federal de Educação, Ciência e Tecnologia.

Uma comunicação voltada para justificar os atos do poder, como descreve Weber (2011), ou para falar apenas das coisas boas, omitindo os problemas, como defendeu um dos entrevistados operadores da comunicação, fere o princípio da máxima divulgação da LAI. Esse princípio está orientado no sentido de que todas as informações possíveis de serem divulgadas, devem sê-lo, portanto, omitir informação para valorizar o lado positivo de uma instituição, vai contra a LAI.

\subsection{Comunicação Pública na visão de Pierre Zémor ${ }^{33}$}

\subsubsection{O acesso à informação}

A Comunicação Pública, para Zémor, cumpre o papel de deixar claro aos cidadãos quais as regras do jogo que se dá na disputa pelo poder envolvendo o Estado. Em seu texto "Les formes de la communication publique" (Zémor, 2009), o autor fala sobre o histórico de publicização das leis do Estado francês permitindo que se entenda que esse tipo de publicidade é uma das formas de comunicação pública. Porém, Zémor alerta que:

Levando em conta seu volume considerável e sua tecnicidade, esses dados só são

33 Pierre Zémor, além de livros e artigos publicados sobre comunicação pública, foi fundador e presidente da Association Communication Publique; presidente da Fédération Européenne des Associations de Communication Publique; presidente da Commission Nationale du Débat Publique. Publicou, dentre outros, os livros La Communication Publique, Pour un meilleur débat publique, Le défi de gouverner, Communication comprise: Mieux associer les citoyens?, e La communication publique en pratiques. É improvável tratar do tema Comunicação Pública no Brasil sem citar as obras dele. Seu livro La Communication Publique foi trazido para o Brasil pela professora da Universidade de São Paulo (USP) Heloiza Matos na década de 1990 (Curtinovi e Mesquita, 2014). Já a professora Elizabeth Brandão fez uma tradução da primeira parte do livro que passou a ser usada e citada em artigos e dissertações por pesquisadores e estudantes brasileiros (Rosso, 2012). Entretanto, utiliza-se neste trabalho uma tradução mais recente, Zémor, 2009, de um dos capítulos do livro, primeiramente, traduzido por Brandão. 
postos à disposição do público, de maneira útil e eficaz, quando estão sob a forma de informações práticas, para serem usadas nos lares e nas empresas. As informações sobre os procedimentos e formalidades administrativas são destinadas a facilitar o exercício de seus direitos e deveres. Para uma pessoa física, essas informações ajudam a declarar um nascimento, obter um passaporte, um visto de permanência, preencher a declaração do imposto de renda, pedir um reembolso de despesas médicas, obter benefícios como a tarifa reduzida em transportes nas agências de emprego, enviar uma correspondência por sedex, declarar um empregado doméstico, justificar a posse de um imóvel, obter uma ajuda judiciária, fazer queixa de um roubo ou de poluições contra o meio ambiente. (ZÉMOR, 2009, p. 216).

Zémor trata do acesso à informação na França e relata ocorrências, no serviço público de lá, que essa pesquisa também encontrou nas instituições da Rede Federal de Educação, Ciência e Tecnologia daqui, questões como a dificuldade de organizar a informação de maneira simples para que o cidadão a compreenda e a utilize. $\mathrm{O}$ autor francês cita várias ações e políticas públicas adotadas pelo Estado na tentativa de facilitar o acesso como o Comité d'Orientacion pour la Simplificacion du Langage Administratif (COSLA) ${ }^{34}$. Para ele, devido à complexidade dos textos e dos procedimentos e também devido às condições em que os cidadãos muitas vezes se encontram, o direito à informação estabelece, para as instâncias administrativas, um dever de comunicação. Assim, o diálogo e mesmo a assistência leva ao estabelecimento de uma relação entre o Estado e o usuário do serviço público.

\subsubsection{A relação entre cidadão e Estado na Comunicação Pública}

Essa relação se baseia nos seguintes princípios: recepção, escuta, diálogo e comunicação.

A recepção é a maneira como o serviço público se prepara para receber o pedido do usuário. Para explicar isso, Zémor chega a falar de questões que vão desde as placas de sinalização nas ruas - que indicam a localização de serviços públicos - como essas devem ser claras ao comunicarem uma mensagem, até o uniforme dos funcionários que fazem o atendimento ao público, pessoas usando uniformes facilitam sua identificação; A recepção é o modo como o Estado se prepara para receber o usuário que busca um serviço. O indivíduo não tem como saber onde funciona uma repartição ou que funcionários podem ajudá-lo, por isso, é preciso que exista sinalização, informando onde está o local para o qual o cidadão deve se dirigir; os funcionários que vão atender ao usuário do serviço público devem estar bem identificados. Tudo isso, para Zémor, é Comunicação Pública.

A escuta é a fase da relação em que o Estado ouve o cidadão, e Zémor fala da necessidade de se ouvir os protestos, mas também os desejos do usuário. A comunicação,

34 Comitê de Orientação para a Simplificação da Linguagem Administrativa, tradução livre. 
nesse contexto de escuta, passa a ter um caráter de consultação e de interação. Por isso, a linguagem do setor público necessita ser simples, precisa fugir da cultura da administração pública e do que o autor francês chama de jargão administrativo. Em outras palavras, para ouvir, o serviço público precisa falar com o cidadão na linguagem dele.

O diálogo, diz Zémor, permite uma coprodução do atendimento personalizado e dá ao usuário do serviço público a qualidade de contratante social junto ao poder público. Isso só ocorre a partir do momento em que é personalizado o atendimento, ou seja, no instante em que o Estado escuta o caso particular. Essa escuta do caso particular é geradora do diálogo e permite que sejam captados pontos que escapam quando se faz apenas ações globais. Esse diálogo foge da pressuposição consumista e não está baseado na ideia de cliente-fornecedor. O diálogo entre Estado e quem usa o serviço público precisa levar em conta que o usuário não vai procurar por serviços ou informações em cada um dos pontos da administração estatal, o cidadão não é "interministerial", o diálogo entre Estado e usuário precisa ter um local específico para isso, um local polivalente de atendimento ao público.

No Brasil, têm ocorrido tais experiências com centros de atendimento ao cidadão que concentram vários serviços como emissão de Carteira Nacional de Habilitação (CNH), Cadastro de Pessoa Física (CPF), Registro Geral (RG), postos de atendimento das companhias de saneamento e de eletricidade, atendimento dos serviços de proteção ao consumidor dentre outros. Sem essas unidades com atendimento variado, o cidadão precisaria fazer uma visita a cada órgão. Com essa concentração de serviços em um só lugar, facilita-se a vida do usuário. Entende-se, assim, que Zémor, ao tratar da necessidade de atendimento interministerial, refere-se a essa questão, e o mesmo vale para as informações. O usuário dos serviços públicos precisa ter um espaço, seja virtual, telefônico ou mesmo físico, onde possa buscar informações, sem a necessidade de peregrinar por muitos setores ou mesmo órgãos públicos.

A comunicação na relação baseia-se na ideia de que a Comunicação Pública faz um atendimento individualizado. O público não deve ser tratado como massa, precisa ter suas especificidades vistas, respeitadas, e deve-se trabalhar a comunicação com base nessas especificidades. Zémor afirma que a publicidade massiva não é a solução para o Estado comunicar-se com a população, mas pode ser utilizada em determinadas situações. Ele diz, também, que os veículos de comunicação podem contribuir para a difusão de dados públicos e encorajar a interatividade dos diálogos com as instituições, mas que, raramente, podem tratar de questões complexas. Esse autor defende que ocorra uma personalização no atendimento do cidadão por parte do Estado, pois, para ele, quando o receptor é ativo, ocorre um melhor 
acesso às informações e também sua memorização.

O autor francês diz que a relação do Estado com o cidadão no serviço público é submetida a quatro exigências:

\footnotetext{
Informar por dever, geralmente na ausência de desejo ou de motivação de compra; assegurar a pedagogia atrelada a uma mensagem complexa; incluir a comunicação no processo de identificação e de entrega do serviço; contribuir para conferir sentido à vida coletiva (ZÉMOR, 2009, p. 225).
}

Vê-se nessas quatro características, uma definição de Comunicação Pública que pode facilitar a compreensão do que seria a CP quando se sai da esfera do Estado. Ou seja, não haveria necessidade de se ser estatal, mas de cumprir esses quatro requisitos. Quando uma instituição fornece informações sem que o objetivo desse fornecimento seja incentivar a compra de um produto ou serviço; se esse ato de informar está constituído didaticamente; se ocorre não apenas disponibilização de informação, mas comunicação tanto na identificação quanto na entrega do serviço; e se esse ato de informar contribui para conferir sentido à vida coletiva; tem-se aí Comunicação Pública, mesmo que praticada por entidades não estatais.

\subsubsection{A promoção dos serviços públicos}

Rabaça e Barbosa (2001) definem promoção como um conjunto de atividades, técnicas e meios que visem a incrementar as vendas ou fortalecer uma marca. No caso citado por Zémor, percebe-se que ele fala de promoção no sentido, tanto de levar os cidadãos a conhecerem os serviços prestados pelo Estado, promoção das marcas estatais, quanto a usarem esses serviços, algo equivalente à promoção de vendas.

De acordo com Zémor (2009), a promoção dos serviços públicos deve ocorrer com base em dois procedimentos, o "fazer saber" e o "fazer apreciar". O primeiro seria tornar disponível o conhecimento, e o segundo seria tornar o serviço prestado pelo Estado mais ativo, mais valoroso ou mais eficaz para o cidadão. Como os serviços oferecidos têm um público muito amplo, exige-se o uso das técnicas da informação de massa.

A publicidade dos serviços ofertados deve ser usada para dar a conhecer as instituições, informar sobre sua existência, prestar informações administrativas, como horários de funcionamento, abertura e fechamento, números de telefone, sites, como obter os serviços e outros. No caso da Lei de Acesso à Informação brasileira, ela está em sintonia com o que Zémor defende, pois manda que os órgãos estatais tornem públicas todas as informações sobre horários, contatos e serviços ofertados. No entanto, nossa lei não determina o uso da comunicação como definida por Martino ou Wolton (2006). Enquanto esses dois 
autores afirmam que a comunicação precisa ser dialógica, a lei brasileira não faz essa exigência ao tratar do acesso à informação.

Para Zémor, não há necessidade de uma comunicação mais personalizada quando for preciso passar aos cidadãos informações de fácil compreensão. A promoção dos serviços públicos, nesses casos, pode ser feita por meio da publicidade, visto que essa técnica pode atingir os usuários de forma massiva.

Além do "fazer saber" e do "fazer apreciar", tem-se também o "fazer usar" e, nesse caso, a publicidade estatal funciona de forma a chamar os usuários a utilizarem determinado serviço e aí Zémor cita como exemplo as manifestações culturais, as exposições, os encontros e as jornadas ou mutirões da Justiça.

Entretanto, o autor francês faz uma ressalva, a publicidade, quando feita para o serviço público, deve levar em conta, mais que em outros casos, que "o que somos fala mais forte do que o que dizemos" (Zémor, 2009, p. 227). A publicidade não pode ser falsa, não retratar a real qualidade do serviço público ofertado.

\subsubsection{Que instituições devem usar a Comunicação Pública}

Zémor faz uma diferenciação quando trata do que ele chama de serviços concorrenciais e serviços universais. No caso dos primeiros, o Estado tende a concorrer com a iniciativa privada. No segundo, essa concorrência não existe ou, ao menos, é pouco comum. Um serviço universal, para citar um exemplo brasileiro, é o Sistema Único de Saúde (SUS) que não precisa disputar usuários com o sistema privado de saúde. Pode-se fazer a equivalência dessas ideias de Zémor com o modelo que funciona no Brasil. Aqui se tem a Administração Direta ${ }^{35}$ que são os órgãos do Estado e que o autor francês chama de Serviço Público e tem-se a Administração Indireta ${ }^{36}$ que são as autarquias, as empresas públicas e as empresas de economia mista. Essas duas últimas, ele denomina Setor público. Na concepção desse autor, na Administração Indireta, com exceção das autarquias, não se aplica a

35 Administração Direta, na definição de Cláudio José Silva, é “a gestão dos serviços públicos pelas próprias pessoas políticas (União, Estados-Membros, Municípios e Distrito Federal) por meio de órgãos que estão integrados em suas estruturas". SILVA, José Cláudio. Resumo de Direito Administrativo. Rio de Janeiro: Editora Ferreira, 2009.

36 Administração Indireta é, na definição de Cláudio José Silva, a descentralização administrativa quando o Estado passa para entidades autônomas, atividades suas. A Administração Indireta pode ser usada também para interferir no mercado como é o caso das empresas públicas e empresas de economia mista. As empresas públicas são de propriedade do Estado, mas atuam no mercado concorrendo com as empresas privadas, caso da Caixa Econômica Federal. Já as empresas de economia mista, que também atuam concorrendo no mercado, têm a propriedade pertencendo ao Estado e particulares, é o caso da Petrobras. SILVA, José Cláudio. Resumo de Direito Administrativo. Rio de Janeiro: Editora Ferreira, 2009. 
Comunicação Pública, pois as empresas estatais participam da disputa no mercado com as empresas privadas. Como exemplo, ele cita a empresa francesa de transporte aéreo, Air France, que precisa se utilizar do marketing para disputar clientes com as empresas privadas.

Contudo, há, entre as empresas privadas e as empresas estatais que não fazem uso da Comunicação Pública, outras instituições que são empresas estatais, mas nas quais a Comunicação Pública se mistura com outras formas de comunicação. Zémor fala de serviços públicos que podem ser ofertados como concorrenciais de serviços privados e cita como exemplo empresas de transporte público que fariam uso da Comunicação Pública, mas também de outras formas de comunicação, pois concorreriam com empresas privadas. Comparando com o modelo brasileiro, pode-se citar a Empresa Brasileira de Comunicação (EBC) que é pública e vai praticar comunicação pública, porém, concorre com empresas privadas na disputa pela audiência e, portanto, vai fazer uso também de outras ações de comunicação, para ganhar telespectadores. Seguindo o critério utilizado nesta pesquisa para definir Comunicação Pública, no sistema de administração pública brasileiro, todas as empresas controladas pelo Estado usam, em alguma medida, a Comunicação Pública.

No Direito Público brasileiro, existe a figura da Autarquia que compõe a Administração Indireta e, neste trabalho, ao fazer a comparação com o sistema francês exposto por Zémor, consideram-se as autarquias brasileiras como usuárias, exclusivamente, da Comunicação Pública, pois prestam serviços públicos que, em regra, não concorrem com empresas privadas. Como os Institutos Federais são autarquias, este trabalho supõe que a Rede Federal de Educação, Ciência e Tecnologia deva trabalhar com Comunicação Pública.

Veja na Tabela 4 a definição do tipo de comunicação de acordo com o tipo de instituição.

\begin{tabular}{|l|l|}
\hline Tipo de instituição & Tipo de comunicação \\
\hline Empresas públicas & $\begin{array}{l}\text { Comunicação Pública e outros tipos de comunicação } \\
\text { para concorrer com empresas privadas. }\end{array}$ \\
\hline Empresas de economia mista & $\begin{array}{l}\text { Comunicação Pública e outros tipos de comunicação } \\
\text { para concorrer com empresas privadas. }\end{array}$ \\
\hline Autarquias & Comunicação Pública. \\
\hline Órgãos da Administração Direta & Comunicação Pública. \\
\hline
\end{tabular}

Tabela 4: Onde se pratica a Comunicação Pública de acordo com a definição de CP adotada neste trabalho e orientada pela visão de Zémor. 


\subsubsection{Comunicação para o interesse geral}

Quando se está em uma democracia representativa, é difícil definir o que é interesse geral. Entretanto, caso se opte por não fazer essa definição, corre-se o risco de abrir mão do uso da comunicação por parte do Estado em suas ações. Zémor fala das campanhas de informação de interesse geral e trata, primeiramente, da comunicação cívica. Ele a define como sendo o resultado das relações permanentes entre as instituições e os cidadãos. Dentre essas instituições, estão as públicas e a família. O autor diz que os desafios de comunicação nesses casos vão além da mera comunicação de direitos e deveres e tratam da necessidade de levar os cidadãos a participarem das discussões públicas. A informação cívica objetiva mostrar como é o funcionamento institucional e político do Estado e como o cidadão pode tomar parte nas decisões que ocorrem nessa estrutura.

As campanhas voltadas para causas sociais ou humanitárias, diz Zémor, encontram menos dificuldades em serem recebidas pela opinião pública. Ele cita como exemplos de campanhas de interesse geral mais fáceis de serem realizadas as de combate ao tabagismo, ao câncer, a prevenção da Aids e as informações sobre pessoas com deficiência.

Por outro lado, para além dessas campanhas cívicas ou humanitárias, há campanhas que Zémor chama de comunicação governamental e que devem contribuir para a implantação e o sucesso de medidas e políticas públicas dos governos. Um exemplo citado pelo autor francês e que se encaixa no caso das instituições usadas como lócus desta pesquisa são as campanhas governamentais de incentivo à formação e à aprendizagem. Os Institutos Federais cresceram, do início da década de 2000, quando eram compostos por 150 unidades, para as atuais 450. Esse crescimento veio acompanhado de campanhas do governo de incentivo a matrículas nessas escolas, foi necessário convencer os possíveis estudantes da importância dos cursos técnicos.

Por último, ainda falando de comunicação para o interesse geral, cita-se o que Zémor chama de temas da sociedade ou civilizatórios, que seriam campanhas realizadas pelos governos no que diz respeito à segurança, direitos e à própria saúde. Todos os tipos de comunicação, seja ela cívica, campanhas de causas sociais, humanitárias ou civilizatórias, ocorrem com certa frequência, independente do governo que está no poder, e devem, ressalta Zémor, evitar que tenham uso político por parte do mandatário do momento. Para ele, a assinatura do governo, da gestão ou do governante deve ser discreta, sob o risco de deixar as campanhas sem credibilidade. A tabela 5 resume as formas de comunicação de interesse geral especificadas por Zémor. 


\begin{tabular}{|l|l|}
\hline Tipo de comunicação & Característica \\
\hline Comunicação Cívica & $\begin{array}{l}\text { Divulgação de informações sobre o funcionamento do } \\
\text { Estado como regras, leis e sistema eleitoral. }\end{array}$ \\
\hline Comunicação para causas sociais ou humanitárias & $\begin{array}{l}\text { Campanhas sobre questões como o tabagismo, } \\
\text { combate à Aids e à violência doméstica. }\end{array}$ \\
\hline Comunicação governamental & $\begin{array}{l}\text { Divulgação de informações sobre políticas públicas do } \\
\text { governo. Muitas vezes em forma de campanhas de } \\
\text { incentivo à participação. Como exemplo se pode citar } \\
\text { o de campanhas de incentivo à aprendizagem. }\end{array}$ \\
\hline Comunicação Civilizatória & $\begin{array}{l}\text { Divulgação de informações sobre direitos, saúde e } \\
\text { outros. Por exemplo, as campanhas que combatem a } \\
\text { discriminação ou incentivem a prática de exercícios } \\
\text { físicos com vistas a melhorar a saúde. }\end{array}$ \\
\hline
\end{tabular}

Tabela 5: Tipos de comunicação de acordo com Zémor.

As observações de Zémor sobre a impessoalidade da comunicação governamental são tema da legislação brasileira. Nossa Constituição Federal indica a forma que ela deve seguir. Em seu Artigo 37, Parágrafo $1^{\circ}$, a Lei Maior determina que a publicidade dos atos, programas, obras e campanhas dos órgãos públicos precisam ter caráter educativo, informativo ou de orientação social. Além disso, é vetado conter, nesse tipo de comunicação, nomes, símbolos ou imagens que caracterizem promoção pessoal de autoridades ou servidores públicos.

Zémor entra na questão ética dessa comunicação do Estado e das dificuldades em lidar com a impessoalidade ao tratar da tentação que os gestores públicos têm de se utilizarem dessa comunicação estatal para beneficiarem a si, seus grupos ou suas ideias. Ele afirma que a ética da comunicação pública se assenta sobre o grau de respeito que cada emissor tem com o consenso social. No entanto, sobre o que não há consenso, ele diz que não é papel da comunicação pública atuar como propagandista de um dos lados, e tampouco ignorar a situação devido às disputas sobre o tema. A comunicação pública deve expor o debate, e não silenciar sobre um assunto por esse ser polêmico ou não haver consenso social sobre ele. 


\section{A visão dos operadores da LAI}

Este capítulo realiza análise de conteúdo das entrevistas feitas com 13 operadores da LAI. Para relembrar, no total, esta pesquisa entrevistou 32 pessoas, sendo 19 operadores da comunicação e 13 operadores da LAI ${ }^{37}$.

\subsection{Categoria 1: Visão dos operadores da LAI sobre a Lei}

Para essa primeira categoria, buscou-se entender como os operadores da LAI veem a lei. Esses operadores são originários de muitas áreas profissionais e atuam em diferentes regiões do País com distintas culturas e formas de ver o Estado e a democracia ${ }^{38}$. São eles os que colocam a lei em prática, no local onde ela é aplicada, os órgãos públicos; daí a necessidade de se compreender como enxergam tal legislação. Políticas públicas podem ser postas em prática por servidores que discordam delas, afinal, tem-se no serviço público brasileiro a figura da estabilidade no emprego em que o servidor pode até ser exonerado, mas em casos muito específicos. Então, se na iniciativa privada, a empresa pode demitir um funcionário que não concorde, não goste ou não esteja totalmente apto para colocar em prática determinada política ou ação, na administração pública isso não ocorre com facilidade. Nessas instituições, a política pública pode ser implementada por alguém que discorde dela, que não tenha interesse no assunto ou até mesmo não tenha a formação e a capacidade para operacionalizá-la. Mesmo assim, em tese, o servidor vai colocar a ação em prática para cumprir uma ordem superior. Nesse cenário, reforçam-se as razões para verificar o que pensam da LAI os servidores públicos que a colocam em prática.

Entre os 13 operadores da LAI entrevistados, todos veem a lei de forma positiva, como ferramenta para a fiscalização do governo e capaz de fazer os fluxos de informação da instituição melhorarem, aumentando, inclusive, o controle interno. Esse posicionamento pode ser observado nas manifestações expostas a seguir.

37 Um entrevistado ocupa legalmente os dois postos, é operador da comunicação e operador da LAI ao mesmo tempo, e um operador da comunicação opera, informalmente, também a LAI. Faz-se necessário explicitar tal informação, pois esse operador informal da LAI deu importantes informações sobre a aplicação da lei. Entretanto, mesmo compondo os dois universos, foi contado apenas uma vez, como operador da comunicação. 38 Os IF's foram interiorizados e se espalharam por muitas cidades do Brasil, desde as regiões mais desenvolvidas do Sul do País até pequenas cidades pobres do Norte e Nordeste. O desenvolvimento político e social dessas áreas varia e pode ser que se encontrem lugares onde exista uma cultura de maior acesso à informação e lugares nos quais impere o costume do sigilo. 
[...] eu acho que é um instrumento de grande valia para o cidadão de um modo geral, é realmente um instrumento de empoderamento mesmo. É também um instrumento de auxílio de combate à corrupção muito grande, mas ela mexe em alicerces muito sólidos, do patriarcado, dessa coisa do domínio, do eu tenho poder, eu posso, eu sou do serviço público, eu sou o Estado, quem é você para estar me questionando? E eu acho que aí também é que está o encanto, de um lado, ela é extremamente cativante porque ela permite o empoderamento do cidadão; por outro lado, também ela impacta muito a administração pública porque é aquela máxima que a gente sempre vê que é a diferença entre o Brasil legal e o Brasil real. A LAI, na letra da lei, ela é maravilhosa, ela tem uma dimensão assim muito profunda, mas a gente também não vê um aparato para que ela se consolide, mas tudo bem, a gente está com dois anos, por força e pressão dos órgãos de controle ela está muito presente porque... eu acho que se a CGU não tivesse puxado pra ela o sistema do Serviço de Informação do Cidadão, certamente as respostas não seriam tão... né. Os números mostram que nós estamos muito bem em termos de resposta.

O cidadão ele pode saber o que acontece aqui, como é que é. É diferente da iniciativa privada, então eu acho que a lei é importante, não só pela questão do serviço, você sabe que também tem outras questões envolvidas com relação à época da ditadura e tudo, a lei é só um pedacinho de um processo muito maior. Eu considero que é importante sim, tem que ter uma divulgação maior dentro da instituição, os servidores devem conhecer sim e aplicar isso com mais efetividade.

Eu acho bastante positiva. Trás um olhar mais criterioso, até a respeito do próprio cidadão em relação às instituições [...]. Então eu acho que é positivo e a parte da transparência também e da padronização das informações das instituições. Hoje, se eu procuro informação de alguma instituição, eu sei exatamente onde olhar, eu busco no espaço de acesso à informação daquela instituição e eu sei que ali eu vou achar o organograma, os relatórios...

Eu acho que é uma lei que só beneficia o cidadão e como ainda é praticamente uma fase de implantação, o cidadão ainda não está utilizando da forma como poderia, mas essa tendência é melhorar e a LAI é importantíssima para a transparência de todos os atos da Administração Pública.

É uma ferramenta de trabalho. Ajudou na organização dos processos internos.

Além de haver unanimidade em considerar a lei positiva, todos os entrevistados apontam como um dos problemas principais a falta de pessoal para operacionalizar a legislação.

O problema é que se determinou que tenha servidor trabalhando com isso, mas não veio servidor para isso. Acabou deixando serviços descobertos, e a LAI não é prioridade. Se tivesse disponibilização de um servidor, isso facilitaria bastante.

No entanto, um operador fez uma ressalva nessa questão da falta de mão de obra. Ele afirmou que há carência de servidores no momento, mas que, a princípio, se opunha à contratação de mais gente, pois quando teve início a implantação da lei, não se sabia quanta demanda de serviço seria gerada. Para ele, o Estado não pode contratar sem ter claramente qual a necessidade dessas contratações, pois corre-se o risco de se ter servidores em demasia, sem necessidade e gerando custos para o País. Na visão desse operador, agora, passados cerca de três anos do começo da implementação da LAI, já é possível afirmar que é necessário 
contratar mais servidores para atuar com a Lei.

Além da falta de mão de obra, houve outra questão levantada pontualmente. Um operador comentou sobre o aumento do volume de trabalho entre os servidores, inclusive entre os que não estão vinculados ao setor que operacionaliza a lei, já que a implantação da LAI trouxe consequências e mudanças para todos os níveis do serviço público.

[...] mas assim, existe essa questão da mudança de postura que a LAI traz, e isso é uma questão que é muito complexa. É um trabalho extra aqui dentro a gente convencer os colegas que tem essa legislação e que ela é legal. E por que eu acho que isso impacta negativamente? Porque são servidores que já têm uma demanda de serviço muito grande e que a ação da LAI, tanto para produzir as respostas das demandas que são criadas, quanto mudar o seu processo de trabalho de forma a garantir a transparência ativa, é um trabalho a mais para servidores que já estão com muita coisa a fazer. Aí vão dizer 'eu tenho o meu processo, e ele já vem assim, assim, assim, então agora, com a LAI, eu tenho que ter outra preocupação que é eu adequar esse meu relatório à linguagem cidadã; que é eu arquivar isso de uma forma que depois possa ser resgatado; que é eu deixar essa informação já disponível para ninguém nem precisar me pedir'.

Síntese da visão dos operadores da LAI sobre a lei:

a) Os 13 entrevistados avaliam a lei como positiva;

b) Os 13 entrevistados entendem que há carência de mão de obra para lidar com a lei;

c) Um entrevistado apontou o aumento de trabalho no serviço público, em consequência da implantação da LAI, como um problema da política de acesso à informação;

d) Apesar de todos apontarem a carência de mão de obra, um operador observou que esse problema exigiu tempo para ser detectado, não podendo ter sido observado logo no início da implementação da lei.

\subsection{Categoria 2: Estrutura de implantação da LAI}

Analisa-se nesta categoria a estrutura administrativa que dá funcionamento à LAI em três aspectos: o primeiro quanto ao modelo de administração da transparência passiva; o segundo quanto ao modelo de administração da transparência ativa; e o terceiro quanto à estrutura física dos setores da LAI.

\subsubsection{Subcategoria 1: Estrutura administrativa da transparência passiva}

A estrutura que dá funcionamento à transparência passiva da LAI varia de uma instituição para outra e se divide em centralizada e descentralizada por setores. Do total de 13 
39

operadores da LAI entrevistados, quatro apontaram que a operação da lei é descentralizada por setores, os outros nove indicaram a centralização.

No modelo de centralização, tem-se um operador que recebe os pedidos de informação e os encaminha para os outros setores internos. Esse mesmo operador recebe as respostas de volta e as repassa para o interessado. Nesse caso, os servidores públicos que recebem os pedidos do operador central não têm nenhuma ligação com a LAI. O operador que centraliza o recebimento de pedidos de informação funciona, dentro da instituição, como uma espécie de perguntador que faz o papel de intermediar as dúvidas do cidadão e, ao mesmo tempo, as respostas a serem para ele encaminhadas. A característica principal do modelo centralizado é que o operador que recebe a pergunta a envia direto para quem tem a resposta na instituição, sem passar por intermediários. O servidor que tem a informação entrega a resposta diretamente para o administrador do e-SIC, também, sem intermediários. Veja a figura 1, na página 72, com o modelo centralizado.

No lado oposto, tem-se o modelo de descentralização em que há vários servidores que lidam com a LAI espalhados por diversos setores da instituição e os pedidos de informação são encaminhados, de forma segmentada, para esses servidores a partir de um operador central, e eles encaminham o pedido para quem tem a resposta. Nesse modelo, existe um intermediário entre o operador que recebe a pergunta do interessado e o servidor que deve oferecer a resposta. Veja a figura 2, na página 73, com o modelo centralizado. Um operador da LAI descreve esse modelo:

[...] veja só, atuando no serviço de informação, especificamente, tem apenas um, que sou eu. Mas, eu não sei se eu já tinha comentado contigo, a parte de respostas ela é feita por cada uma das áreas por uma pessoa indicada pra mim, que faz o assessoramento para mim para efeito de resposta [...].

Esses servidores descentralizados não lidam constantemente com a lei, apenas esporadicamente quando há pedidos específicos para os seus setores.

Além da descentralização por setores internos como pró-reitorias, departamentos e núcleos, há Institutos Federais que trabalham com uma descentralização por campus, havendo um servidor ou operador da LAI em cada um dos campi da instituição ${ }^{40}$. Veja como é

39 Operação da lei é o cumprimento de um conjunto de atividades e processos administrativos que foram estabelecidos pela LAI e que devem ser cumpridos por entes públicos ou privados sem fins lucrativos quando usam dinheiro público.

40 Não foi possível verificar quantos dos 13 operadores da LAI apontaram essa divisão por campus, pois tal questão surgiu a partir do momento em que os entrevistados a indicaram. Surgida a questão, passou-se a 
descrito esse funcionamento:

Nós montamos uma rede para responder demandas que a gente não consiga responder aqui na Reitoria. Designamos em cada campus uma pessoa responsável pelo SIC que também acumula funções. Então, hoje, nos 11 campi em funcionamento nós temos uma pessoa que é o nosso contato com relação à rede SIC. Essa pessoa é que vai nos municiar com informações para que a gente possa responder. Exemplificando, um suposto pedido de informação com o seguinte: qual o horário de trabalho do professor Joaquim José no Campus? A princípio, essa informação deveria estar ativa, deveria estar na página, mas hoje nem página o Campus tem. Essa pergunta entra aqui, como a lei prevê [..]. Eu não tenho essa informação aqui, mas já tem uma pessoa no Campus que a gente vai acionar pra dar essa informação.

Então a gente manda essa demanda pra essa pessoa, ela é designada pelo diretor da escola, geralmente é alguém da confiança dele, e ela busca essa informação, repassa essa informação pra cá, e a gente alimenta o sistema. Essa pessoa do campus ela não tem acesso ao sistema, quem tem acesso é só daqui da Reitoria.

Entretanto, esse modelo descentralizado por campus apresenta problemas. Um operador descreveu que, formalmente, ocorreu a descentralização, sendo que existem dois servidores responsáveis pela LAI em cada um dos campi, porém, o sistema não funcionou. Nesse caso, todos os responsáveis pela LAI nos campi teriam também acesso ao portal eletrônico e-SIC, dessa forma responderiam às perguntas sem passar pelo administrador central que fica na Reitoria.

Note que são duas possibilidades diferentes: na primeira, o operador que fica na Reitoria pede informação a um servidor no campus, esse faz o pedido a quem tem a informação e repassa de volta para o operador que está na Reitoria, e ele coloca a resposta no sistema.

No segundo caso, o próprio operador que está no campus lida com o sistema recebendo as perguntas e respondendo-as. Mas, como se observa na fala seguinte, o sistema com operadores descentralizados respondendo diretamente no e-SIC, não está funcionando.

\footnotetext{
Vou te colocar a nossa situação atual, o que acontece? A estrutura dos Institutos ela é composta da Reitoria e de diversos campi. Na época da implantação nós tivemos algumas dúvidas a respeito de como isso funcionaria aqui dentro. Na época nós cadastramos no sistema dois representantes por campus para que fizessem o atendimento das demandas do SIC, mas, na prática, tem se efetivado apenas as respostas cadastradas por meio da Reitoria, por dois atendentes do SIC da Reitoria. Então, hoje eu posso te dizer assim, no sistema até nós temos mais pessoas cadastradas por causa dos campi, mas, na prática, quem tem centralizado e encaminhado essas respostas são as duas servidoras da Reitoria.
}

trabalhá-la, porém, não era possível retomar entrevistas já realizadas para verificar esse dado. Foi possível contabilizar o modelo de descentralização por campus em, pelo menos, quatro instituições do total de 13 . Nas outras nove, não foi feito esse levantamento nem os entrevistados a apontaram. 
Figura 1: Modelo centralizado

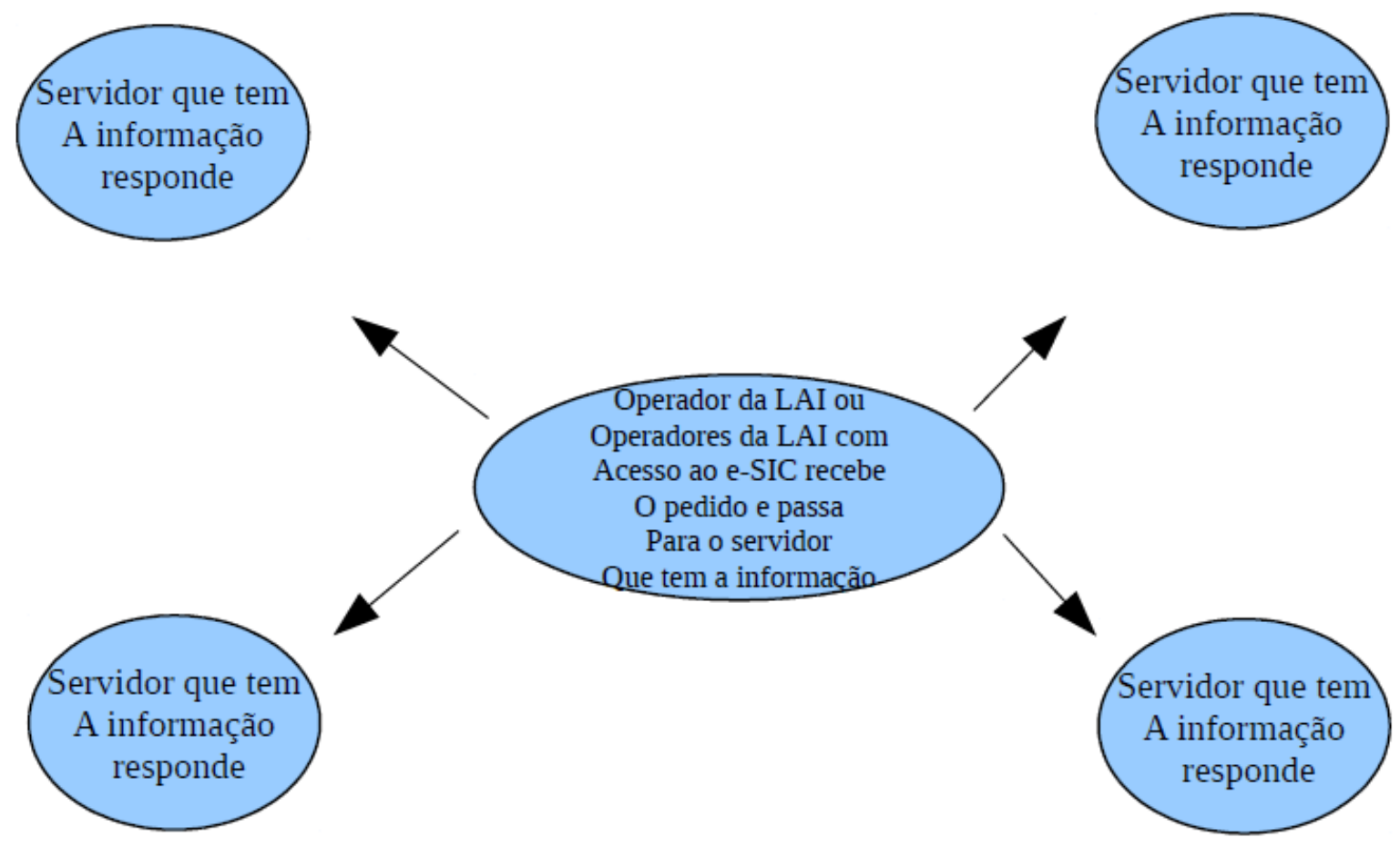


Figura 2: Modelo descentralizado.

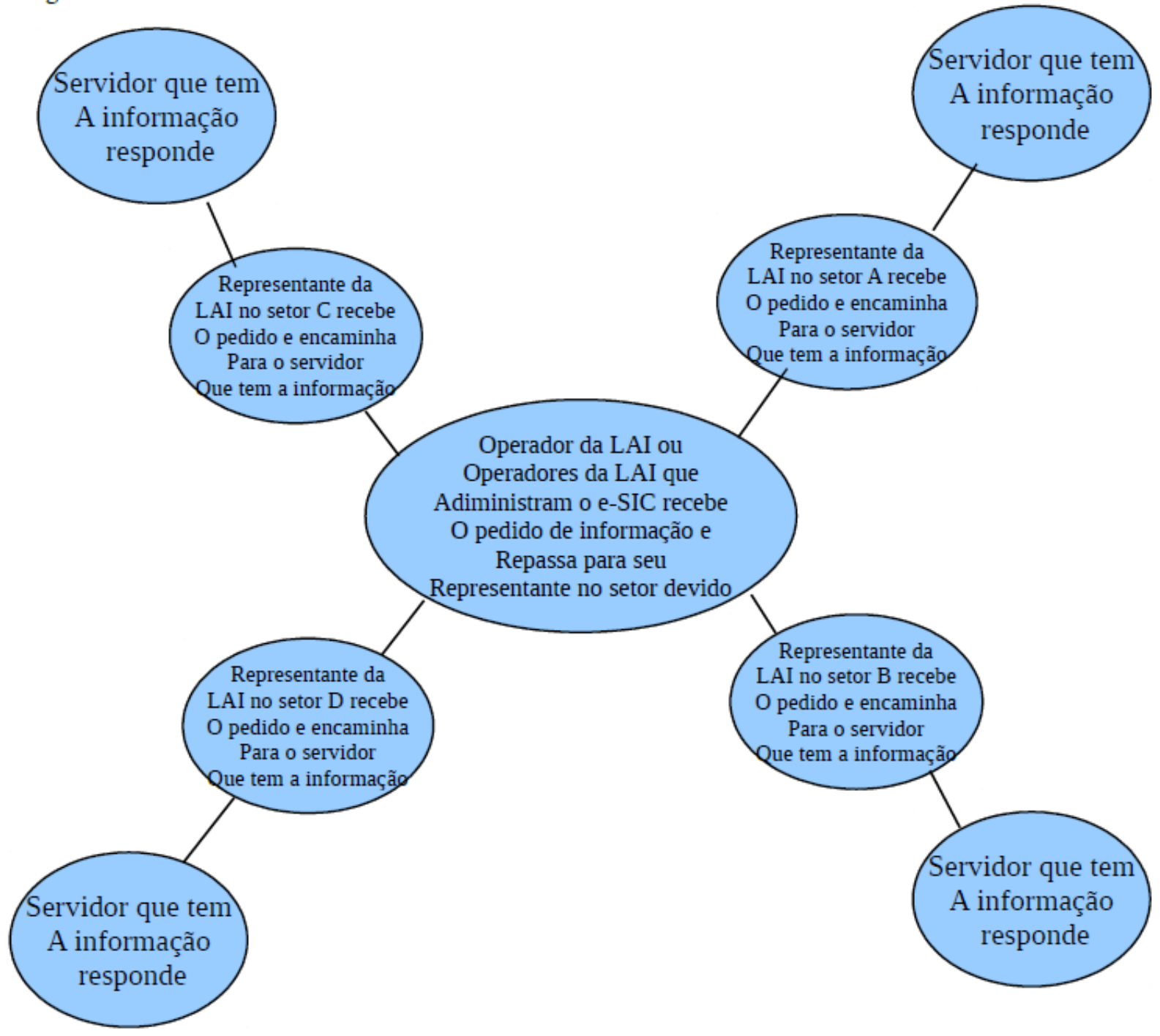


Síntese do que foi levantado sobre a estrutura da transparência passiva nos IF's:

a) A administração da transparência passiva ocorre de maneira centralizada e descentralizada por setores;

b) O modelo de centralização e descentralização também ocorre por campus;

c) No caso da centralização, apenas um operador recebe as perguntas e as encaminha para o funcionário que tem as respostas, podendo esse operador central enviar tais perguntas para qualquer funcionário de setor sem passar por nenhum intermediário. Nove IF's descreveram esse processo;

d) No modelo de descentralização por setores, o operador que recebe as perguntas, as envia para outros servidores dentro de cada setor da instituição, e estes, como intermediários, encaminham os questionamentos para servidores daquele setor que tem as informações. As respostas fazem o mesmo caminho de volta. Quatro IF's descreveram esse processo;

e) Na centralização que envolve os campi, apenas um operador, que fica na Reitoria, recebe as perguntas e as envia para o servidor que tem a resposta;

f) $\mathrm{Na}$ descentralização por campus, cada um dos campi da instituição tem um operador da LAI ou um servidor que vai atrás das respostas.

\subsubsection{Subcategoria 2 - Estrutura administrativa da transparência ativa}

Nenhum dos 13 entrevistados apontou a existência de controles formais sobre as rotinas ou processos administrativos da transparência ativa ${ }^{41}$. A respeito disso, um operador explicou que existe a intenção de se estabelecer o planejamento e o controle sobre a publicação de informações da transparência ativa, porém, esses ainda não existem.

\footnotetext{
Entrevistador: Existem já rotinas, processos administrativos para isso [controle da publicação de informações da transparência ativa]?

Entrevistado: Não. Ainda não.

Entrevistador: E vocês pretendem estabelecê-los?

Entrevistado: Sim, pretendemos. A gente formou a comissão, mas como todos têm outras atividades, a gente não pode exigir muito, e outras demandas acabam passando à frente [...]. Não tem um planejamento formal.
}

A questão da falta de sistemas de controle sobre a administração da transparência ativa foi explicitada por outro operador da LAI que diz haver apenas um trabalho com questões pontuais, ou seja, às vezes se produz informação de acordo com uma demanda momentânea

41 Há uma dificuldade dos operadores da LAI em tratar do tema transparência ativa, e isso se mostrou na pesquisa no momento em que se faziam perguntas direcionadas para a transparência ativa, mas o entrevistado, muitas vezes, respondia, falando de transparência passiva. 
que seja verificada. Como exemplo, pode-se citar o caso do Exame Nacional do Ensino Médio (Enem), quando ele está em curso, o operador da LAI verifica que tem havido muitas perguntas sobre o tema e determina que se publiquem mais informações sobre tal assunto no site da instituição.

Ainda de acordo com esse operador, foi implementado no site institucional o rol mínimo de informações conforme determinado pela Controladoria-Geral da União e, a partir daí, não se estabeleceram formas de gerir essas informações de modo a garantir que sejam mantidas atualizadas. Veja as afirmações do operador da LAI que entra nesse ponto:

Entrevistado: [...] a gente não tem tido condições de fazer esse controle ainda. Porque nós não temos levantado ainda quais seriam os principais problemas, por exemplo, nós tivemos um pique grande em relação a um concurso público, então aí a gente atua tentando resolver aquele problema específico ali. Mas a gente sabe que tem um problema maior atrás, que exige um tratamento maior, mas que também, como em tudo no serviço público, que envolve muito recurso, porque você não resolve o problema de divulgação de um site sem mexer num site todo, porque é uma ação muito complexa. Então, assim, pontualmente a gente tem uma ação, corrige isso, veja aquilo, mas não é nada que seja quantificável [...].

Entrevistador: Como funciona esse processo de construção da transparência ativa? Entrevistado: O rol mínimo está lá desde a implantação da lei e aí na medida em que aparecem outras necessidades [...]. Agora a promoção da informação no ambiente do site, por exemplo, ela também é pontual, na medida em que eu vejo o problema, porque [...] não consegui localizar tal informação no site ou tal informação não está disponível ou não foi possível o acesso porque não conseguiu se chegar até lá, porque é difícil você navegar e ir atrás dessas informações ou porque essas informações realmente não existem. Então eu provoco mediante uma recomendação da Ouvidoria, 'olhe está faltando tal e tal informação, eu andei no site assim, assim, e o linque que está dando, não está dando para a informação certa', então há uma provocação nesse sentido até que se corrija a informação.

Entrevistador: Mas existe um processo administrativo já estabelecido?

Entrevistado: Não, enquanto processo, não, porque, na verdade, é uma tramitação a partir da provocação. A gente identifica o problema e procura sanar o problema da divulgação daquela informação solicitada.

Mesmo sem rotinas formalmente estabelecidas e indicadas claramente pelos entrevistados, foi possível identificar, em suas falas, processos de produção e publicação das informações da transparência ativa nos sites dos Institutos estudados. Todos os operadores da LAI afirmaram que, de alguma maneira, avaliam a produção da transparência ativa ao verificarem os sites das suas instituições para observar se há necessidade de se acrescentar ou modificar informações disponibilizadas ao público. Porém, nenhum deles informou com qual periodicidade realizam essa verificação, indicando, assim, não haver um método definido para tal.

A falta de rotinas formalmente definidas gera problemas. Para além da falta de controle, foi verificado que, nos casos em que ocorreram troca de operadores, o operador que 
assume o cargo precisa repensar como fazer o trabalho e tem necessidade de reinventar a forma de trabalhar, pois não encontra modelos de ação definidos e documentados sobre como fazer a transparência ativa. Dois dos 13 operadores entrevistados descreveram situações assim.

Entrevistador: E a transparência ativa é você que produz?

Entrevistado: Não sou eu. Não sei se a outra [pessoa que deixou o cargo] era a responsável porque ela não me passou.

As únicas formas de acompanhamento da atualização das informações, apontadas pelos operadores da LAI, estão relacionadas com a descoberta ao acaso de erros pelos próprios funcionários, pelas verificações feitas sem periodicidade, ou quando ocorre a reclamação de um usuário.

Foram apontados como responsáveis por colocar as informações da transparência ativa nos sites: os setores de tecnologia da informação, os setores de comunicação, o próprio gestor da LAI e, inclusive, em um instituto, chegou-se a dizer que qualquer pessoa que tenha a senha de acesso ao site da instituição pode publicar. Nesse último caso, foi explicado que cada setor do IF tem uma senha específica do site e quando tem informações para postar, um determinado servidor se ocupa disso. Veja a fala de dois operadores da LAI sobre essa questão.

Nós temos o apoio da comunicação e da TI, não é um trabalho exclusivo da pessoa que cuida da LAI. A servidora da LAI manda um memorando para os setores e eles respondem. A mesma servidora acompanha a publicação das informações ativas no site, mas é a comunicação que mais cuida disso e vai publicando as informações de acordo com a chegada delas.

A promoção da informação no ambiente do site, por exemplo, ela também é pontual, na medida em que eu vejo o problema, porque não consegui localizar tal informação no site $[\ldots]$

As falas dos entrevistados indicam que a publicação das informações da transparência ativa leva o setor da LAI a aproximar-se de vários outros setores da instituição. Entende-se que essas ações precisam ser coletivas, necessitam do apoio de todas as áreas do órgão público. No momento de publicar e atualizar as informações, o setor da LAI se aproxima da comunicação, pois a disponibilização das informações no site está, muitas vezes, sob controle dos setores de comunicação, como indica a fala a seguir. 
essas questões. Eles, periodicamente, verificam nos nossos portais, tanto no portal principal quanto nas nossas unidades, se existem informações que estão listadas na legislação e estão presentes nas nossas páginas. Então é um trabalho que é dividido entre as equipes do SIC e da comunicação.

Um operador relatou que estão sendo estabelecidos processos administrativos e formas de controle para a publicação e atualização de informações de forma proativa. Com isso, busca-se constituir novos hábitos para todos os membros da instituição. Nesse caso, a realização da transparência ativa está sendo pensada para que ocorra de forma descentralizada com vários servidores postando informações no site. Essa descentralização já ocorre em partes e sem planejamento, pois todos os 13 entrevistados apontaram que existem vários servidores que publicam informações e não há uma pessoa que faça o controle, de forma central, de tais publicações. Entretanto, o que o operador da fala seguinte pretende é conscientizar a todos os funcionários sobre a questão da transparência de modo que haja um empenho coletivo na sua divulgação.

[...] a questão da transparência ativa, nós tentamos aqui no Instituto trabalhar na Reitoria como um todo, como um assunto de gestão. Claro, nós temos no nosso portal todo aquele menu que a própria lei trouxe como uma base para dispor algumas informações, para padronizar. Mas de resto, de divulgar informações, de publicar outro tipo de informação, a gente tem tratado disso como uma demanda de gestão da instituição. Então isso significa que setores sistêmicos procurem divulgar no portal o maior quantitativo de informações, baseado na transparência ativa, mas a gente ainda está em construção disso em busca do ideal. [...] O portal ele tem uma administração que cada setor pode ter um responsável por alimentar as informações. Então, por exemplo, eu estou na pró-reitoria de administração e tenho acesso para alimentar o site com informações aqui da pró-reitoria. Então nós buscamos publicar a maior parte de informações que a gente consegue de relatórios, de documentos de orientação, como são nossos procedimentos. Então cada setor tem um responsável por alimentar essas informações.

Outro operador da LAI que se manifestou de forma semelhante, disse que há necessidade de se convencer os membros da instituição a agir. Há, na visão desse operador, uma cultura do segredo nas instituições públicas que precisa ser vencida para que a transparência ativa se efetive. Diz ele:

\footnotetext{
Não está bem arraigado. A gente tá tentando que se tire da gaveta, coloque na internet, mas além de se colocar na internet que se atualize, né, nós temos uma dificuldade por causa da cultura. Mesmo sendo lei, usando a caneta [...] até quando a gente lembra se faz alguma coisa, mas depois cai no esquecimento, na rotina do dia a dia e se começa a esquecer disso e tem que ir de novo [...] é um processo contínuo.
}

Um dos operadores informou uma ação de transparência que poderia servir de modelo para outras instituições. $\mathrm{O}$ entrevistado diz que existem sistemas informatizados internos por 
onde correm os processos e que, a partir do momento em que a LAI entrou em vigor, esses sistemas foram abertos ao público, de forma que os dados antes restritos a servidores com senhas tornaram-se livres.

Em uma situação hipotética, um sistema de controle do almoxarifado, por exemplo, em que se retira uma caneta do estoque e a saída daquela caneta é registrada no sistema. Essa informação estaria na rede mundial de computadores e qualquer pessoa poderia acompanhar em tempo real como está sendo a utilização de materiais do almoxarifado daquela instituição. Porém, trata-se de uma possibilidade que exigiria mais que abrir os dados, seria preciso colocá-los de forma que pudessem ser facilmente compreendidos.

No caso da instituição na qual se encontrou essa ação, apenas as licitações e contratos contam com esse sistema aberto que não é de fácil manuseio e compreensão. Quem quiser utilizá-lo precisa ter conhecimentos mínimos sobre administração pública. Veja o que diz o operador da LAI que descreveu essa ação.

\begin{abstract}
A transparência ativa quando foi, tinha aquela data limite para implementar. O que nós fizemos? Nós já tínhamos alguns sistemas internos nossos que favoreciam essa questão da informação ativa. Por exemplo, a parte de contratos, nós tínhamos um programa interno que é o licitateca que mostrava todas as licitações, todos os contratos, então o que nós fizemos? Nós incorporamos isso ao menu previsto na Lei de Acesso à Informação. Isso é alimentado por várias pessoas, na realidade não foi criado um trabalho extra, nós pegamos os sistemas que nós rodávamos aqui e quando eles têm relação a algum tipo de informação, nós estamos linkando os mesmos de modo que a pessoa quando está alimentando o sistema interno também está alimentando o sistema externo.
\end{abstract}

Apesar desse cenário geral que pode indicar certa desorganização quanto à publicação e atualização de informações de forma proativa, os dados mínimos parecem estar sendo publicados, porém, em espaços outros que não o dedicado à LAI nos sites dos IF's. Esse desvio do destino, para o qual as informações deveriam fluir ao final, ocorre pelo fato de o Portal da Transparência do governo federal ter um sistema de controle e cobrança mais 42 rígido , e os servidores públicos terminam enviando dados para esse portal com a frequência determinada pela legislação enquanto ignoram o espaço da LAI em seus próprios sites. Dessa forma, pode-se verificar que a transparência ativa, em parte, está ocorrendo e sendo monitorada. Porém, esse acompanhamento não acontece pelas próprias instituições utilizadas

42 O Portal da Transparência é administrado diretamente pela GCU, o que faz com que os órgãos do serviço público mantenham um fluxo de informação contínuo para ele, já que o próprio órgão fiscalizador faz a administração e consequentemente o controle. Esse Portal foi criado em 2004, portanto, pode-se afirmar que já existe uma cultura de uso e manutenção dele, o que contribui para a maior adesão do funcionalismo público à sua estrutura. 
aqui como amostra, mas pela Controladoria-Geral da União. Essa situação acaba por tornar a Lei de Acesso à Informação em um instrumento que responde a perguntas, ou seja, faz funcionar a transparência passiva, mas deixa a desejar na transparência ativa.

Os dados como listas e salários de servidores, licitações e contratos já estão disponíveis no Portal da Transparência do governo federal. Assim, nessa dimensão mais ampla, esse tipo de informação disponibilizada que compõe a transparência ativa parece funcionar. Entretanto, a transparência ativa que precisa ser feita pelo operador da LAI na instituição está falhando, pois, como foi indicado pelos 13 entrevistados, não há nenhuma rotina administrativa ou sistema de controle formal sobre esse trabalho. Nessas informações que enfrentam falha na publicação, incluem-se números de telefones, endereços, formas como solicitar serviços ou os nomes e contatos profissionais de dirigentes. Esses dados, de acordo com todos os 13 entrevistados, foram inseridos nos sites em maio de 2012, quando a lei entrou em vigor, mas não se estabeleceu ao longo do tempo nenhuma forma de controle sobre o processo de renovação e atualização, o que pode comprometer a validade desses conteúdos.

Síntese do que foi levantado sobre a estrutura administrativa da transparência ativa nos IF's:

a) Nenhum dos 13 entrevistados apontou a existência de controles formais sobre as rotinas ou processos administrativos da transparência ativa;

b) Mesmo sem rotinas formalmente estabelecidas e indicadas claramente pelos entrevistados, foi possível identificar, em suas falas, processos que dizem respeito à produção e publicação das informações da transparência ativa nos sites dos Institutos estudados;

c) As únicas formas de acompanhamento da atualização das informações estão relacionadas com a descoberta, ao acaso, de erros pelos próprios funcionários, pelas verificações feitas sem periodicidade, ou quando ocorre a reclamação de um usuário;

d) Foram apontados como responsáveis por colocar as informações da transparência ativa nos sites: os setores de tecnologia da informação, os setores de comunicação, o próprio gestor da LAI e, inclusive, em um instituto, chegou-se a dizer que qualquer pessoa que tenha a senha de acesso ao site da instituição pode publicar;

e) Apesar desse cenário geral que pode indicar certa desorganização quanto à publicação e atualização de informações de forma proativa, os dados mínimos parecem estar sendo publicados em parte dos IF's;

h) A abertura de sistemas internos poderia contribuir para melhorar a transparência ativa. 


\subsubsection{Subcategoria 3 - Estrutura física dos setores da LAI}

Quanto à estrutura física, dos 13 entrevistados, 12 informaram que não existe uma sala de trabalho exclusiva para o setor da LAI. Os espaços são divididos com setores como ouvidorias, auditorias e corregedorias. Essa situação é vista com normalidade pelo fato de todos os servidores que atuam com a lei desempenharem outras atividades laborais em suas instituições.

Apesar de compartilharem ambientes de trabalho com outros setores, sete dos treze entrevistados consideram essas estruturas boas, pois contam com computadores, armários para arquivo de documentos e linhas telefônicas para atendimento. No entanto, um operador relatou falta de computador e telefone, havendo necessidade de utilizar equipamentos de outros setores.

Um operador da lei sugeriu que seria interessante um número de telefone em que os usuários fossem atendidos de forma ampla com todas as informações. Apesar de o entrevistado não ter usado o termo, ao que parece, seria algo semelhante a um call center, que centralize informações via telefone. As entrevistas indicaram que as estruturas físicas da LAI conseguem fazer um atendimento básico, mas não atendem as determinações da lei como, por exemplo, local apropriado para atendimento presencial e mesmo salas adequadas para que se lide com documentos, por vezes, sigilosos.

Apenas um operador informou existir uma sala exclusiva para atender o usuário de modo privado. Nenhum dos 13 entrevistados indicou a existência de local de atendimento presencial exclusivo para a LAI com a devida sinalização e balcão dentro das instalações de suas instituições. O Artigo $9^{\circ}$ da Lei de Acesso à Informação determina que as instituições ofereçam um local adequado para atender e orientar o público sobre as formas de acesso às informações, esclarecer como se dá a tramitação de documentos, e receber requerimentos solicitando informações. Nenhum dos 13 entrevistados informou se o IF no qual trabalham apresenta, em todas as suas unidades, a estrutura física necessária para prestar o atendimento ao usuário nas condições determinadas pela lei.

Síntese do que foi levantado sobre a estrutura física dos setores da LAI:

a) Dos 13 entrevistados, 12 informaram que não existe uma sala de trabalho exclusiva para o setor da LAI. Os espaços são divididos com outros setores;

b) Sete dos treze entrevistados consideram essas estruturas boas;

c) As entrevistas indicaram que as estruturas físicas da LAI conseguem fazer um atendimento básico, mas não atendem a todas as determinações da lei. 


\title{
4.3 Categoria 3: Visão dos operadores da LAI sobre a comunicação
}

Todos os operadores entrevistados afirmaram haver entre os setores da LAI e da comunicação uma boa relação que se pauta, principalmente, pelo apoio da comunicação à LAI quando é necessário publicar informações institucionais nos sites dos IF's. Os 13 operadores veem no setor de comunicação competência técnica para trabalhar uma linguagem mais adequada à compreensão do público. Entendem que esse setor pode contribuir para conscientizar a comunidade sobre a importância da lei e citam a presteza em postar informações como uma característica do jornalismo que pode trazer benefícios para o processo de aplicação da LAI.

\begin{abstract}
Entrevistador: Como é a relação entre o setor responsável pela LAI e o setor responsável pela comunicação?

Entrevistado: Sempre foi muito próxima, desde a implantação da lei que a gente tem uma relação muito próxima e a comunicação é sensibilizada para todas essas ações. [...] Até para a transparência ativa, para a divulgação da LAI internamente eu preciso da comunicação para pensar nisso aí desde o manual de identificação, de finalização e identificação que estão gerando, até mesmo a produção de documentos e folhetos, a produção de material informativo, a agilidade de postagem de novas informações no site, nos atendem com muita presteza quando eu vejo alguma coisa que não esta certa, a gente passa um $e$-mail e de imediato tem a resposta, a gente está sempre se copiando para eu ficar sabendo quais foram as ações tomadas em relação a isso e eu copio ele.
\end{abstract}

Muito bom, muito boa a relação. Todas as nossas solicitações são atendidas prontamente. Existe uma preocupação desse setor em relação a linguagem, em relação a necessidade de veicular, de deixar de fácil acesso algumas informações que a gente acha importante.

O setor de comunicação está se estruturando agora. E esse contato é bom, mas não é suficiente porque os servidores que trabalham com a LAI têm outras funções e não têm disponibilidade. Acaba não sendo suficiente esse contato.

Entrevistador: Como é a relação entre os setores da LAI e da comunicação? Entrevistado: É muito bom.

Apesar de os operadores afirmarem a existência de uma boa relação entre os setores da LAI e da comunicação, verificou-se que ela ocorre de forma pessoal, não havendo uma institucionalização das práticas de contato entre os dois setores, o que gera dificuldades quando os responsáveis pela LAI ou pela comunicação são substituídos. Ao serem indagados sobre como se dá essa relação no dia a dia, perguntou-se também qual o nível de interação que se estabelecia entre os dois setores e se ocorriam reuniões periódicas entre eles. Todos os entrevistados informaram que não ocorrem reuniões periódicas entre os setores da LAI e da comunicação. Dos 13 respondentes, 12 informaram que nem mesmo uma única reunião 
ocorreu entre esses dois setores. Apenas um operador da LAI relatou uma reunião. As poucas ocasiões em que servidores da LAI e da comunicação se encontraram foram nos primeiros momentos de implantação da lei, oportunidades nas quais se reuniram comissões estabelecidas pelos institutos para monitorar as medidas a serem adotadas a partir das determinações da nova legislação sobre acesso à informação pública.

Um operador da LAI se queixou do fato de não terem uma relação mais articulada e disse que o setor da Lei de Acesso à Informação se sente "meio órfão" em relação à comunicação, pois gostaria que houvesse uma relação mais próxima na qual a comunicação desse um maior apoio às atividades da LAI. Nas entrevistas, não foi encontrado planejamento de ações conjuntas entre LAI e Comunicação. Veja como os entrevistados descrevem essa relação, do ponto de vista de ações institucionais conjuntas.

\begin{abstract}
Entrevistador: Como é a relação entre o setor de comunicação e o setor da LAI? Vocês costumam ter reuniões periódicas?

Entrevistado: Não. Até eles, hoje, como eu te disse, como as pessoas que estão respondendo [pela LAI] são vinculadas ao gabinete, a nossa coordenadoria de comunicação social também é vinculada ao gabinete, mas é um trabalho paralelo. Até hoje não teve nenhuma reunião com esse intuito. Como eu te disse, especificamente a transparência ativa já foi tratada em reuniões de gestão, inclusive também essa comissão que foi formada pra tratar, para dar acessibilidade ao portal, envolveu a comunicação social, mas comunicação social e a lei de acesso ainda não teve nenhum trabalho conjunto. Quando foi pra divulgar a lei de acesso aqui na instituição sempre se usou aquele material que a própria CGU disponibilizou, material informativo, folder, eletrônicos também.
\end{abstract}

Entrevistador: Periodicamente, hoje, existem reuniões entre a comunicação e a LAI? Entrevistado: Não, porque a Lei... aquela questão do atendimento, a lei previa, salvo engano, a criação de um grupo de trabalho para implementar. Após a implantação, a lei previa uma pessoa, a autoridade responsável pelo monitoramento, ela não prevê, legalmente falando, a existência de um grupo de trabalho, embora devesse ter a existência do mesmo. Então o grupo foi formado, trabalhou 30 ou 40 dias até se chegar no portal, o que vai ter, quem vai ter que acionar. Depois ficou só a autoridade. Então, hoje, assim, a gente fica meio órfão de ter alguém, um grupo para poder discutir, o que pode ser melhorado.

No levantamento realizado nos sites das instituições pesquisadas, pôde-se verificar que as informações publicadas não estão em dados abertos ${ }^{43}$, ou seja, dados oferecidos ao público

43 Dados abertos são definidos em oito princípios estabelecidos em 2007 por um grupo de trabalho de 30 pessoas reunidas na Califórnia, Estados Unidos. São eles:

1. Completos - Todos os dados públicos são disponibilizados. Dados são informações eletronicamente gravadas, incluindo, mas não se limitando a documentos, bancos de dados, transcrições e gravações audiovisuais. Dados públicos são dados que não estão sujeitos a limitações válidas de privacidade, segurança ou controle de acesso, reguladas por estatutos.

2. Primários - Os dados são publicados na forma coletada na fonte, com a mais fina granularidade possível, e não de forma agregada ou transformada. 
em formatos digitais que possam ser lidos por máquina, outros computadores, e que estejam editáveis. Como exemplo de formato editável, pode-se citar os programas word e excel da Microsoft e, como contraponto, há o formato PDF. Essencialmente, a diferença é que, nos dois primeiros, é possível retirar os dados copiando e colando, sem alterar qualquer informação. Dentre todos os entrevistados somente um informou haver problemas na relação com o setor de comunicação. De acordo com ele, já foram feitas solicitações ao setor para que não se publiquem informações em dados não abertos, porém, os pedidos não foram atendidos.

\begin{abstract}
Entrevistador: Como é a relação do setor da LAI com o setor da comunicação? Entrevistado: A gente sempre pede para eles publicarem em formato aberto e sempre que o pessoal mandar material para eles que mande em formato aberto para que possa ser usado pelo público, mas colocam muito PDF e imagem de documento. Isso dificulta o uso e o processamento como, por exemplo, pelo pessoal da Transparência Hacker.
\end{abstract}

A CGU fala muito na questão de documentos abertos e formatos de acesso livre. O que acontece? Muitos dos nossos documentos até mesmo os validados pelo TCU, a maioria deles nós publicamos em formato não editável, ele tem acesso livre, mas não em formato editável como Word e Excel, a gente publica em PDF devido a natureza da maioria desses documentos, muitas vezes são documentos digitalizados, Então acaba sendo a maior parte dessas publicações em PDF a não ser aqueles documentos necessários que o usuário vá editar ou vá preencher, fazer algum cadastro. Mas os nossos editais, por exemplo, a maioria deles é em formato PDF,

3. Atuais - Os dados são disponibilizados o quão rapidamente seja necessário para preservar o seu valor.

4. Acessíveis - Os dados são disponibilizados para o público mais amplo possível e para os propósitos mais variados possíveis.

5. Processáveis por máquina - Os dados são razoavelmente estruturados para possibilitar o seu processamento automatizado.

6. Acesso não discriminatório - Os dados estão disponíveis a todos, sem que seja necessária identificação ou registro.

7. Formatos não proprietários - Os dados estão disponíveis em um formato sobre o qual nenhum ente tenha controle exclusivo.

8. Livres de licenças - Os dados não estão sujeitos a regulações de direitos autorais, marcas, patentes ou segredo industrial. Restrições razoáveis de privacidade, segurança e controle de acesso podem ser permitidas na forma regulada por estatutos. (Conceitos utilizados pelo governo brasileiro disponível em http://dados.gov.br/dados-abertos/, acessado em 24 de novembro de 2014).

Do ponto de vista desta pesquisa, analisando esse assunto que está ligado mais às questões de tecnologias da informação que da comunicação, percebe-se que estão com a razão dois dos entrevistados que afirmaram que uma informação quando disponibilizada em formato PDF ou em imagem, não pode ser considerada um dado aberto, do ponto de vista da comunicabilidade daquele dado e da facilidade de seu uso. Uma planilha disponibilizada em um sistema como o Excel ou o Calc pode ser manuseada de forma a extrair dali informações de maneira rápida e fácil. Planilhas em grande quantidade, imagine-se, por exemplo, que um pesquisador queira verificar quantos jornalistas trabalham no serviço público federal e o Ministério do Planejamento tenha disponibilizado a lista com o mais de um milhão de servidores públicos em formato de imagem, caberá ao investigador ler manualmente página por página, encontrar os dados que lhe interessa e digitalizá-los. Caso essa mesma planilha fosse disponibilizada em formato Calc ou Excel o pesquisador ou interessado poderia fazer uma forma de busca e colagem que lhe permitiria ter acesso a tais dados em muito menos tempo. Portanto, concorda-se com os entrevistados quando eles afirmam que informações disponibilizadas em formatos PDF e imagem não são dados abertos, pois não podem ser manuseadas e manipuladas por máquinas de forma a facilitar seu uso por cidadãos com conhecimentos básico de informática. 
todos são abertos, mas não em formato editável.

Síntese do que foi levantado sobre a visão dos operadores da LAI sobre a comunicação:

a) Todos os operadores entrevistados afirmaram haver uma boa relação entre os setores da LAI e da comunicação;

b) Apesar de os operadores afirmarem a existência dessa boa relação, pôde-se notar que ela ocorre de forma pessoal, não havendo institucionalização;

c) Todos os entrevistados informaram que não ocorrem reuniões periódicas entre os setores da LAI e da comunicação;

d) Dos 13 respondentes, 12 informaram que nem mesmo uma única reunião ocorreu entre esses dois setores;

e) No levantamento realizado nos sites das instituições pesquisadas verificou-se que as informações publicadas não estão em dados abertos.

\subsection{Categoria 4: Similaridades entre as funções da LAI e da Comunicação}

Nessa categoria, procura-se verificar similaridades da LAI e da comunicação. O que se deseja saber é se os operadores da lei veem algo comum entre seu trabalho e o desenvolvido pelos setores de comunicação de suas instituições. A primeira pergunta feita a esses operadores da LAI foi: O senhor considera que os veículos de comunicação do IF fazem transparência ativa?

A LAI, a literatura e a CGU definem transparência ativa como aquelas informações que o Estado divulga sem ser provocado, sem ser perguntado. Seguindo essa definição ao extremo, um guarda de trânsito, ao informar aos motoristas que eles devem seguir à esquerda e não à direita, está fazendo transparência ativa. Portanto, procurou-se saber o que os operadores da LAI entendem por transparência ativa e se o trabalho de publicitários, jornalistas, programadores visuais e outros profissionais da área da comunicação é considerado como transparência ativa na visão dessas pessoas.

Os 13 operadores da LAI entrevistados concordam que os trabalhos realizados pelos setores de comunicação devem ser considerados uma forma de transparência ativa, pois as atividades desenvolvidas pelos profissionais das assessorias buscam fornecer informações, e essa ação está entre os objetivos da Lei de Acesso à Informação. Um operador da LAI apontou o site institucional como o principal instrumento de que dispõem os institutos para 
promoverem a sua transparência ativa. No entanto, um operador fez uma ressalva de que, dentro da instituição, a comunicação não é vista como uma parte da LAI. Veja as falas dos operadores, onde eles expressam essas questões.

\begin{abstract}
Entrevistador: Você considera que os meios de comunicação do Instituto são transparência ativa?

Entrevistado: É uma transparência ativa, eu acredito que sim. É um meio de você estar fornecendo algum tipo de informação, principalmente o jornal seja eletrônico ou impresso, é uma maneira de você estar divulgando ou informando a comunidade sobre serviços ou acontecimentos. Então eu considero como um elemento que faz parte da informação, que estaria no leque dos objetivos da Lei de Acesso à Informação. Não sei qual é o objetivo principal ao se emitir um jornal, que não é a minha praia, mas que ao lançar um jornal você está atendendo alguma coisa da Lei de Acesso eu acredito que sim.
\end{abstract}

Entrevistador: Você considera que os veículos de comunicação que vocês têm fazem parte da transparência ativa?

Entrevistado: Fazem. Hoje a gente trabalha basicamente com o portal. Nós temos uma espécie de revista que traz também para o público informações da instituição, mas principalmente é o portal. Como eu te disse ainda não está no ideal que a gente gostaria com relação à transparência ativa, mas a gente está buscando que seja aprimorado.

Entrevistador: O senhor considera que os veículos de comunicação do IF fazem transparência ativa?

Entrevistado: Faz também. Agora tá faltando melhorar a qualidade, porque além de publicar tem que fazer uma pesquisa e ver como o pessoal tá entendendo isso.

Entrevistador: Você considera que os veículos de comunicação do Instituto fazem parte da transparência ativa?

Entrevistado: Nós temos a página institucional, mas a LAI não produz informação própria. Mas considero que sim, mas ela não é taxada, pelo menos internamente, como transparência ativa.

Para observar se os operadores da LAI veem alguma diferença entre a transparência ativa e a comunicação, foram questionados se essas duas definições são a mesma coisa. Dos 13 entrevistados, três afirmaram que sim, e os outros 10 disseram que não. No grupo dos 10 que não consideram a comunicação como transparência ativa, encontram-se afirmações que ponderam, em alguma medida, essa visão. Alguns chegaram a dizer que "de certa forma" esses dois conceitos são iguais ou "complementares". A comunicação seria, nas palavras deles, para "divulgar", para "falar de coisas boas", não teria um "compromisso com a transparência". Pode-se, assim, resumir a visão dos operadores da LAI, nessa questão, afirmando que, para eles, o setor de comunicação da instituição funciona como propagandista, já a transparência ativa teria um compromisso concreto com os fatos. Enquanto a comunicação pode omitir informação para proteger o IF, a transparência ativa é obrigada a expor as informações. Essa visão se confirma nas seguintes manifestações. 


\begin{abstract}
Entrevistador: Você entende transparência ativa e comunicação como sendo a mesma coisa?

Entrevistado: Não. São coisas diferentes. Pra você vê... a diferença que eu vejo é a seguinte, o que busca o jornal? Em tese procurar o lado, vamos dizer assim, bom das coisas, ele procura divulgar eventos, prêmios alcançados por alunos ou professores, coisas que vão acontecer. A LAI ela tem o objetivo de mostrar tudo, o jornal não vai falar, vai ter uma licitação para a compra de ar-condicionado, o salário do reitor é 10 mil reais. Não se presta pra isso o jornal. O jornal procura puxar esse lado, vamos dizer assim, bom da instituição, de dar esse lado. Na Lei de Acesso a Informação vem essa informação? Vem, mas o foco principal dela não é esse, na minha opinião, o foco principal dela é informar todos os processos que envolvem a instituição com o objetivo de você procurar uma informação relativa a você mas também a outros processos alguma coisa desse tipo.
\end{abstract}

Entrevistador: Se eu afirmar que transparência ativa e comunicação são a mesma coisa. Você concorda com essa afirmação?

Entrevistado: Não. Eu acho que não exatamente, concordo parcialmente, devem estar vinculadas, mas a Lei de Acesso tem toda uma construção, ela é bem profunda. [...] A comunicação, acho que é complementar, é para divulgar [...].

Entrevistador: Se eu afirmar que comunicação e transparência ativa são a mesma coisa. Você concorda?

Entrevistado: Acho que são próximas, quase sinônimas. A comunicação é mais ampla que a LAI.

Para os operadores da LAI, comunicação é, também, transparência ativa, é uma parte dela, porém, é algo menos nobre. Enquanto a LAI teria um compromisso mais profundo com a disponibilização de informações e as exporia sem qualquer preocupação com quem será atingido por tal divulgação, excetuando-se os casos de sigilo legal, a comunicação teria uma função propagandística e, em consequência, um compromisso menor com a transparência. Deduz-se das falas dos entrevistados que, enquanto a LAI tem seu compromisso maior com a disponibilização das informações, a comunicação teria seu compromisso maior com a boa imagem da instituição. As informações disponibilizadas pela LAI poderiam até prejudicar a instituição, as publicadas pela comunicação, se forem prejudicar a instituição, não devem ser publicadas. Isso fica explícito na fala citada acima em que o entrevistado diz que a LAI "é bem profunda” e que a comunicação "é complementar, é para divulgar”.

Síntese do que foi levantado sobre as Similaridades entre as funções da LAI e da Comunicação:

a) Os 13 entrevistados concordam que os trabalhos realizados pelos setores de comunicação devem ser considerados uma forma de transparência ativa;

b) Dos 13 entrevistados, três afirmaram que LAI e comunicação são a mesma coisa, 10 disseram que não;

c) Para os 10 que entendem não serem a mesma coisa, a comunicação serviria para 
“divulgar", "falar de coisas boas", não teria um “compromisso com a transparência”.

\subsection{Categoria 5: Visão da transparência ativa}

Os operadores da LAI têm opiniões diferentes quanto à clareza das informações da transparência ativa, mas a maioria vê problemas na linguagem.

Para 11 dos 13 operadores entrevistados, as informações não são compreensíveis. Apenas dois avaliaram a transparência ativa como clara o suficiente. Os que veem problemas quanto à clareza, enxergam uma necessidade de se avançar nessa questão, mas foram comedidos no momento de verbalizar essa crítica ${ }^{44}$. Observou-se que ocorrem pedidos de explicação a respeito de informações disponibilizadas na transparência ativa e, segundo um operador, isso mostra que o usuário final acessa a informação, mas não a compreende.

O relato de um dos operadores entrou em detalhes sobre essa questão da clareza e da capacidade de compreensão das informações pelo usuário. Ele avaliou que os dados precisam ser disponibilizados em uma linguagem mais simples, pois, mesmo quando se escreve uma informação pensando no estudante do Instituto Federal, isso não é suficiente, visto que os alunos que estão ali já passaram pelo Exame Nacional do Ensino Médio (Enem) ou por outro processo seletivo, e a maioria da população está, na visão desse operador, abaixo da média desse aluno da instituição. Na visão de outro operador, o fato de essas instituições serem acadêmicas também atrapalha a produção de informações em linguagem simples, pois há, nas palavras dele, uma dificuldade em convencer quem escreve a "baixar o nível da linguagem ao qual se está acostumado".

Dois operadores manifestaram a opinião de que a responsabilidade pela falta de clareza é da CGU, afirmando que parte das informações é dada a partir de linques do Portal da Transparência $^{45}$ e que esse não é claro; Outros dois disseram que as informações dos relatórios feitos pelos auditores como as prestações de contas, por exemplo, são, sim, claros e compreensíveis, pois são escritos de forma "coerente".

Foi possível observar que os operadores que afirmaram que a linguagem de questões técnicas é clara estão ligados à área de auditoria. Já os operadores ligados a outros setores,

\footnotetext{
44 Foi comum, durante as entrevistas, que o entrevistado fizesse uma longa pausa, antes de responder, ou que usasse expressões corporais que indicavam contrariedade com a linguagem. Nas entrevistas ao telefone, falas como "hum...", "bem, essa questão aí é...", “Ah! A linguagem...". O entrevistado parecia querer expressar uma crítica à forma como está a transparência ativa, mas no momento de verbalizar sua opinião, havia uma formalidade na crítica, certo comedimento.

45 O Portal da Transparência é mantido e administrado pela CGU.
} 
com formação na área de informática ou comunicação, fazem parte do grupo que reclamou das prestações de contas apontando-as como não compreensíveis nem mesmo para os servidores da instituição. Essa situação indica que os operadores da LAI que tiveram contato com a comunicação em suas formações têm uma postura crítica em relação às informações da transparência ativa.

Segue a opinião de alguns operadores da LAI, que veem a linguagem como acessível.

Entrevistador: $\mathrm{Na}$ sua opinião as informações da transparência ativa estão em linguagem cidadã?

Entrevistado: Sim.

Entrevistador: As informações do site estão em linguagem técnica ou houve uma adaptação?

Entrevistado: Adaptação não. Até porque as publicações da nossa própria página já são acessíveis.

Entrevistador: Em relação às informações de licitações, por exemplo, você entende que um cidadão comum consiga lidar com essas informações?

Entrevistado: Na questão das licitações eu acredito que... não entendo que dificuldade um cidadão teria para navegar, compreender as informações, até porque os editais e relatórios não tem jogo de palavra, nem vocabulário muito técnico. A própria CGU nos orienta a fazer os relatórios de forma que seja compreensível para o cidadão. É uma linguagem bem acessível.

Entrevistador: $\mathrm{Na}$ sua opinião as informações da transparência ativa estão em linguagem cidadã?

Entrevistado: Os nossos relatórios, tanto os relatórios de gestão, quanto os relatórios de auditoria são apresentados em linguagem acessível e sempre em formato de texto. Eles são extensos, mas a gente busca sempre com que, dentro das orientações do próprio TCU, com que eles sejam... de maneira clara, coerente, então eu acredito que sim.

A posição de um operador da LAI não ligado aos setores de auditoria e que afirma haver dificuldades na linguagem:

Entrevistador: E a linguagem?

Entrevistado: Bom, assim a iniciativa da CGU é fantástica, a gente só tem que elogiar, é uma ferramenta fabulosa. A questão da linguagem você tem a linguagem de um órgão público que é muito mais técnica, de fornecer aquela informação, a gente nota ainda que existe por anos e anos, as pessoas se recusarem, ter dificuldade de dar uma informação, ainda é um pouco resistente. É público, isso aqui ó, uma declaração emitida, isso aqui tem que ser público, não tem nenhum segredo e antes tinha uma coisa de não, não pode. Então tem um pouco disso que acaba influindo na linguagem, a pessoa tem [...] ah! Tal portaria, tal ofício recebido pelo reitor, tal ofício respondido pelo reitor! Isso não é sigiloso não, onde o reitor estará na semana que vem tem que estar na página, tem que estar na agenda. Então essas facilidades que a lei te permite, eu acho que por falta de [...] quando foi lançada [a LAI], o foco foi outro. Perdeu-se uma grande oportunidade de mostrar ao cidadão comum o que ele pode obter de informação e a linguagem que foi usada pra colocar todos os dispositivos que ele tem acesso pecou. Eu não sei explicar porque não é minha área, mas fato é o seguinte que corre o risco, se a CGU ou outro órgão não fizer campanhas e mais campanhas de conscientizar as pessoas de que existe isso, corre o risco de ficar o que? A gente meramente cumprir uma obrigação que nos foi 
imposta, deixa de ser uma ferramenta e passa a ser o cumprimento de uma legislação.

\begin{abstract}
Entrevistador: A CGU fala em linguagem cidadã, na sua opinião, essas informações da transparência ativa estão compreensíveis para todos os cidadãos?

Entrevistado: Olha, a minha opinião é que não, nós temos muito a melhorar ainda nesse sentido. No meu entender isso pode ser melhorado.
\end{abstract}

Entrevistador: Prestações de contas, relatórios, auditorias, você acredita que a população consegue compreender essas informações?

Entrevistado: Não, eu acredito que não.

Entrevistador: As informações da transparência ativa, na sua opinião, elas são compreensíveis para o cidadão comum?

Entrevistado: Eu penso que está numa linguagem clara. Mas no geral, informações sobre licitação, por exemplo, elas são mais difíceis mesmo. A questão dos relatórios de gestão, por exemplo, não está claro nem mesmo para os servidores da instituição, devido a forma como estão padronizados esses relatórios.

Ao longo das entrevistas verificou-se uma mistura muito grande de opiniões entre os 13 operadores da LAI quanto à clareza das informações. Entretanto, todos eles reconhecem que, em algum grau, há dificuldade do cidadão em lidar com a massa de informações técnicas.

Síntese do que os operadores da LAI pensam sobre a transparência ativa:

a) A maioria, 11 de 13 entrevistados, avalia que a linguagem usada não está clara;

b) Dois operadores manifestaram a opinião de que a responsabilidade pela falta de clareza é da CGU;

c) Dois disseram que as informações dos relatórios feitos pelos auditores são claras e compreensíveis;

d) Os operadores que afirmaram que a linguagem é clara estão ligados à área de auditoria;

e) Já os operadores com formação na área de informática ou comunicação reclamaram das prestações de contas, apontando-as como não compreensíveis;

f) Todos reconhecem, no entanto, que, em algum grau, há dificuldade do cidadão em lidar com a massa de informações técnicas.

\title{
4.6 Categoria 6: Perfil profissional dos operadores da LAI
}

Foi possível verificar o perfil profissional de 12 dos 13 operadores da LAI entrevistados. Foram encontradas as seguintes características:

1. Um operador graduado em Ciências Contábeis que acumula o cargo de chefe de auditoria da instituição; 
2. Um graduado em Letras que ocupa também o cargo de ouvidor da instituição;

3. Um graduado em Engenharia com pós-graduação nas áreas de Informática e Administração e que ocupa o cargo de ouvidor da instituição;

4. Um graduado em Administração que ocupa o cargo de diretor do Departamento de Desenvolvimento Institucional;

5. Um graduado e com pós-graduação em Relações Internacionais e que ocupa também o cargo de assessor para assuntos internacionais e ouvidor da instituição;

6. Um docente com formação em Engenharia de Minas que ocupa uma série de coordenações como a de vestibular, a do Programa Nacional de Acesso ao Ensino Técnico e ao Emprego (PRONATEC), a de Assistência Estudantil e é também assessor do reitor;

7. Um psicólogo, que ocupa o cargo de assessor de relações internacionais da instituição;

8. Um graduado em Sistemas de Informação que é assessor de avaliação institucional e responde, interinamente, pela Ouvidoria da instituição nas ausências do ouvidor titular;

9. Um graduado em Relações Públicas que é também ouvidor da instituição;

10. Um jornalista que ocupa, ainda, os cargos de ouvidor e secretário da Comissão de Ética;

11. Um docente graduado em Letras que é, ao mesmo tempo, chefe de gabinete do reitor;

12. Um auditor que é também diretor de campus.

É possível observar uma ligação dos operadores da LAI com os sistemas de controle da instituição. Entende-se por sistemas de controle duas formas:

1. Um sistema de controle institucionalizado, como no caso dos auditores, chefes de auditoria, ouvidores e servidores da área de desenvolvimento institucional, que cumprem nessas instituições a função de planejamento e controle administrativo;

2. O outro sistema de controle é o político, ou seja, é possível inferir que os operadores da LAI são pessoas ligadas aos chefes máximos da instituição, o reitor. Nesses casos, essa ligação se materializa quando se verifica que os operadores ouvidos também têm outros cargos de confiança na instituição além do cargo de autoridade da LAI.

Esses perfis apontam que pode ter havido uma preocupação dos reitores em colocar na 
operação da LAI pessoas que já tinham um conhecimento dos sistemas de controle ligados à CGU como ouvidorias e auditorias.

Para esta pesquisa, é interessante a verificação desses perfis, pois aqui se entende que a LAI é uma dimensão da comunicação. Uma das questões que leva a essa afirmação é que o Fórum de Acesso à Informação ${ }^{46}$, entidade que exerceu contínua pressão sobre o governo e o Congresso Nacional para aprovar a LAI, teve grande participação de instituições ligadas à imprensa e à comunicação. Dessa forma, o que se observa é que, enquanto a pressão da sociedade para a criação da LAI veio da área de comunicação, depois de aprovada, ela parece ter sido encampada pelos sistemas de controle do governo como ouvidorias, controladorias e auditorias. Não há proximidade com os setores de comunicação.

Todos os operadores entrevistados disseram ter atividades paralelas na instituição, não havendo funcionário que lide apenas com a LAI. Ao explicar essa falta de servidores exclusivos para trabalhar com a lei, os entrevistados emitem opiniões contraditórias, primeiro afirmam que não há servidores exclusivos para a lei, pois a demanda de trabalho é muito baixa, logo, não há necessidade. Porém, quando questionados sobre os problemas da transparência ativa, afirmam que a falta de servidores pode ser uma explicação para a ausência de planejamento e controle dessa parte da LAI.

Síntese do que foi levantado sobre o perfil profissional dos operadores da LAI:

a) Os operadores da LAI estão ligados aos sistemas de controle da instituição;

b) Os operadores da LAI têm proximidade com os reitores;

c) Nenhum operador dedica-se exclusivamente ao trabalho com a lei.

\subsection{Categoria 7: Relações entre operador e usuário da informação}

Zémor (2009) afirma que, devido à complexidade dos textos, dos procedimentos e mesmo das situações em que os cidadãos se encontram, o direito à informação gera um dever de comunicação por parte do serviço público. Com base nessa ideia, estabeleceu-se essa categoria para verificar como os operadores da LAI veem o usuário, se expressam alguma intenção de comunicar, se fazem algum esforço nesse sentido e, principalmente, como os operadores avaliam a forma como os usuários recebem as informações.

Os pontos comuns observados na fala dos operadores da LAI quanto à apropriação que o usuário faz ou não das informações públicas são:

46 Ver capítulo 1 sobre a história da aprovação da LAI no Brasil, onde são apresentadas informações sobre o Fórum de Acesso à Informação. 
1. Os 13 operadores apontaram que há uma dificuldade em se medir como ocorre essa apropriação, pois não existem sistemas para verificar o que o usuário faz com a informação ou para que ele a quer;

2. Os 13 entrevistados apontaram que falta conhecimento da população a respeito da lei, o que dificulta a apropriação da legislação pelos cidadãos e, consequentemente, a apropriação das informações públicas e dos processos para obtê-las.

Um operador detalhou essa opinião da falta de conhecimento da lei que impede a apropriação da informação:

\begin{abstract}
Essa questão da falta de comunicação, dele conhecer, das funcionalidades, essa apropriação, ela ocorre muito pouco porque poucas pessoas conhecem essas funcionalidades. Poucos cidadãos... você veja que a grande maioria dos que acessam a informação são os próprios servidores públicos, é o nosso caso. Você não vê um cidadão comum, aquele de fora, pedindo tanto informação. Você vê muito mais servidores nossos ou de outras instituições que estão com dificuldade de obter uma informação, utilizarem a LAI. É interessante isso. É o que não entra na minha cabeça, a pessoa vai num departamento pede uma informação, a pessoa lá amarra, enrola ou não responde, aí o perguntante fica 'p' da vida e vai na LAI. Aí você pega a pergunta e manda para a mesma pessoa e ela responde, então porque o infeliz foi lá e não respondeu? Então vai entender o ser humano, né. Mas... então eu acho que essa apropriação não ocorreu muito ainda por falta de conhecimento das funcionalidades, repito, houve um boom de informação que levou muito para a época da Ditadura e também da questão dos salários. Salário até já existia, já tinha essa iniciativa. $\mathrm{O}$ foco da comunicação foi muito em cima disso e se perdeu uma grande oportunidade de falar do resto, de $99 \%$ das coisas que a Lei de Acesso à Informação permite. [...] Eu acredito que ainda há tempo, a CGU foi muito feliz de colocar a lei, mas falta um trabalho de divulgar a lei. Não está ocorrendo isso. Tem que ter divulgação e ser de uma forma sistemática e poder dar visibilidade para as pessoas ficarem mais à vontade de acessar.
\end{abstract}

Além da falta de informações sobre a lei, a inexistência de uma cultura de controle social do Estado por parte dos cidadãos é, na visão dos operadores, um empecilho a uma boa implementação da LAI.

Todos os operadores apontaram que existe um uso da lei para atender a interesses individuais. De acordo com eles, os usuários buscam informações sobre nomeação em concursos públicos; há fornecedores em busca de dados sobre licitações; e pessoas que, aparentemente, buscam informações com o intuito de obterem dados para se municiarem em disputas políticas ou pessoais com colegas de trabalho. Veja a descrição desses dois operadores:

O usuário busca questões muito particulares, ele não busca informações para o bem público. Os pedidos de informação são questões bem pontuais buscando interesses 
particulares.

[...] ou então professores que tem rixa com outro, querem saber da vida do outro, mas não podem pedir diretamente porque senão caracteriza perseguição, então pede de todo o Instituto. Pô! Tem um professor aqui que sabe-se que ele tem problema com um departamento, com um professor de um departamento, e pra alimentar essa briga desse departamento ele pede tudo de todos os funcionários, o tempo todo, onze processos o tempo todo.

Um operador da LAI afirmou que o cidadão comum não usa a lei e que os pedidos partem, em sua maioria, de pessoas que têm algum tipo de relação com a instituição perguntada, principalmente servidores públicos. Os operadores não têm quantificado quantos dos pedidos partem de pessoas ligadas à instituição, mas ao menos três operadores disseram acreditar que grande parte dos pedidos vem de servidores públicos. Veja o que fala um operador sobre isso:

\footnotetext{
Entrevistador: Como você vê a apropriação da informação pelo usuário?

Entrevistado: A grande maioria dos usuários da LAI são universitários, quem têm acesso a serviços de informática. Então assim, eu acho que continua, esse círculo está muito fechado naqueles que sabem. $\mathrm{O}$ cidadão comum ele não se apropriou da Lei de Acesso à Informação até mesmo para aqueles direitos primários, para ele ter consciência de que ele tem direito, ele não sabe nem que tem uma lei que dá acesso a ele saber do que acontece para poder ter esse direito. O cidadão comum, eu acho que ele ainda está distante da lei, eu tiro por média aqui, a grande maioria das nossas demandas é do público interno. Quer dizer, as pessoas se prevalecendo do prazo da LAI que é 30 dias, que é menor que a lei de processo administrativo, por exemplo, que é 60 dias. Eu acho que o usuário comum, ele ainda está distante.
}

Nessa relação do usuário com a LAI, os 13 operadores da lei entrevistados afirmaram que grande parte das informações pedidas pelo sistema e-SIC, na transparência passiva, já estavam disponíveis no site da instituição por meio da transparência ativa. Mesmo assim, eles observam que o usuário insiste em fazer a pergunta. Diante desse contexto, foi posta aos operadores a questão de como eles analisam essa situação. As avaliações apresentadas transitaram entre a autorresponsabilização por uma suposta má qualidade e confusão dos sites das instituições, uma possível falta de hábito de leitura dos usuários e o analfabetismo funcional e a "preguiça" que os usuários possuem de buscar as informações sendo "mais fácil" perguntar pelo SIC. Um operador afirmou que o usuário é acomodado, mas assumiu a corresponsabilidade pela situação diante da falta de clareza nas informações disponibilizadas. Em medidas variadas e com formas de se manifestarem diferentes, todos (os 13 entrevistados) colocam a responsabilidade desse fato, em parte ou no todo, no usuário. 
aquela informação no site, eu vejo muito disso. A pessoa sabe que existe a Lei de Acesso à Informação, mas assim, eu quero pesquisar o contrato daquele moço ali porque eu acho que aquele moço tem parentesco com o diretor do campus e está roubando. Essa informação está disponível, mas como é que ele vai chegar nela? O site, ele é muito seco, então essa questão, se você tivesse elementos de comunicação que facilitasse essa pessoa buscar aquilo, se eu quero saber isso, como é que eu faço? Não tem isso. Ah! Se eu quero saber se uma empresa tem contrato com o Instituto. Essa informação está ativa, mas o usuário acessa lá e não consegue, ele não consegue o caminho para isso, só o usuário mais experiente conseguiria, aí manda e pergunta no SIC.

A partir das falas dos operadores, pode-se inferir que a apropriação da informação pelo usuário vai se constituir em uma via de mão dupla, primeiro o Estado precisa se instrumentalizar para dar acesso às informações; segundo, a população precisa conhecer a lei, ter noções dos seus direitos; e, finalmente, dar uma utilidade prática para a legislação. A apropriação da LAI pela sociedade em geral ainda precisa ser ampliada.

Síntese do que foi levantado sobre as relações entre operador e usuário da informação:

a) Todos os entrevistados (13) apontaram que falta conhecimento da população a respeito da LAI;

b) Todos os operadores (13) apontaram que existe um uso da lei para atender a interesses individuais;

c) Três operadores disseram acreditar que grande parte dos pedidos vem de servidores públicos;

d) Todos os operadores (13) afirmaram que parte das informações pedidas, por meio do e-SIC, já estavam disponíveis no site da instituição. 


\title{
5. Como os operadores da comunicação veem a LAI
}

Partindo da afirmação de Zémor (2009) de que o acesso à informação tem o dever de comunicar, esta análise da LAI está pautada pela comunicação. Compreende-se comunicação aqui em três sentidos complementares que abrangem desde uma perspectiva técnica até a que considera a sua dimensão humana e social e que são definidos por Rabaça e Barbosa (2002) e por Menezes (1973). No primeiro, entende-se comunicação como:

Conjunto dos conhecimentos (linguísticos, psicológicos, antropológicos, sociológicos, filosóficos, cibernéticos etc.) relativos aos processos de comunicação (RABAÇA e BARBOSA, 2002, p. 155).

A segunda definição é desses mesmos autores que afirmam ser a comunicação:

\begin{abstract}
Atividade profissional voltada para a utilização desses conhecimentos e técnicas através dos diversos veículos (impressos, audiovisuais, eletrônicos, etc.), ou para a pesquisa e o ensino desses processos. Neste sentido, a comunicação abrange diferentes especializações (jornalismo impresso, jornalismo audiovisual, publicidade e propaganda, marketing, relações-públicas, editoração, cinema, televisão, teatro, rádio, etc.), que implicam funções, objetivos e métodos específicos (RABAÇA e BARBOSA, 2002, p. 155).
\end{abstract}

Cita-se ainda Menezes (1973), que diz:

\begin{abstract}
Comunicação significa 'estar em relação com'. Representa a ação de pôr em comum, de compartilhar as nossas ideias, os nossos sentimentos, as nossas atitudes. Nesse sentido, identifica-se com o processo social básico; a interação. É uma troca de experiências socialmente significativas; é um esforço para a convergência de perspectivas, a reciprocidade de pontos de vista e implica, dessa forma, certo grau de ação conjugada ou cooperação. Para tanto, toda sociedade adota um conjunto de signos e de regras que, por força das convenções tácita e coletivamente aceitas, deixa de ser arbitrário. Daí que, se optássemos por símbolos inteiramente novos e estranhos, isso nos isolaria do resto da comunidade (MENEZES, 1973, apud RABAÇA e BARBOSA, 2002, p.157).
\end{abstract}

Essas três definições entram em sintonia com as reflexões teóricas com as quais dialogo e que estão centradas em pensar a Comunicação Pública. A primeira definição permite considerar a LAI em todas as suas dimensões, sendo ela um instrumento de comunicação relacionado a conhecimentos linguísticos, sociológicos, antropológicos e, inclusive, ressaltase com mais força, cibernéticos. Ou seja, a execução da LAI implica, necessariamente, na utilização desses conhecimentos por parte dos usuários e dos operadores das instituições para que se efetivem as determinações e consequências dos seus ditames legais.

A segunda definição de que a comunicação também é uma atividade profissional baseada em um processo com viés técnico, leva a pensar a LAI como dependente dessas 
atividades, seja na elaboração e disponibilização de informações por meios impressos, online, através da radiodifusão ou de qualquer outro canal. E mais que isso, a LAI exige de todos os profissionais do serviço público, ligados ou não às atividades específicas da comunicação, que sejam capazes de bem se comunicarem, tanto entre si quanto com o público usuário.

Por fim, a citação de Menezes (1973) encaixa-se na ideia central do referencial teórico deste trabalho, ou seja, de que comunicação é, fundamentalmente, o estabelecimento de uma relação. Entende-se aqui que é função principal dos setores de comunicação responsabilizarem-se por estabelecer, de formas distintas, relações entre as múltiplas partes das comunidades com as quais os institutos estejam vinculados. Este trabalho vê a LAI como um instrumento que se relaciona com a comunicação e, por isso, incluíram-se os operadores da comunicação como entrevistados na pesquisa para entender como eles estão lidando com a nova legislação.

Já que a LAI é, para este trabalho, parte da comunicação, procurei saber o que os operadores da comunicação pensam sobre a lei e como se relacionam com o setor administrativo responsável pela operacionalização e cumprimento das medidas que a nova legislação estabelece no âmbito público.

\subsection{Categoria 1: Nível de conhecimento da LAI}

Dentre os 19 operadores da comunicação que foram entrevistados, 17 não fizeram qualquer curso de capacitação sobre a Lei de Acesso à Informação, e 2 tiveram algum tipo de preparo. O primeiro, pelo fato de desempenhar simultaneamente o papel de operador da comunicação e da LAI, fez um curso ministrado pela CGU.

\footnotetext{
Entrevistador: Enquanto servidor da comunicação você teve algum treinamento para lidar com a LAI?

Entrevistado: Não. Voltado especificamente para servidores da comunicação não. A gente participou porque seria do SIC.
}

O segundo operador que recebeu capacitação afirma que a Controladoria-Geral da União (CGU) ofertou uma palestra sobre a LAI, mas apenas ele, dentre os operadores da comunicação da sua instituição, compareceu como gestor do seu setor:

A gente teve uma palestra com uma pessoa da CGU que foi aberta a todos, mas eu acho que, basicamente, na palestra só estava eu (da comunicação).

Um dos operadores que não fez qualquer curso informou ter tido contato com a LAI 
fora do ambiente do serviço público federal:

Por incrível que pareça, eu tive contato com a Lei de Acesso à Informação no curso de graduação em História. Eu terminei no ano passado, em dezembro. Lá eu tinha uma disciplina de arquivística histórica, e a professora passou uma tarefa sobre a Lei em função da organização dos arquivos. Ela estava tentando mostrar para a gente o quanto é importante as instituições organizarem seus arquivos até para terem respaldo legal no momento de uma demanda do público externo. Então a gente deu uma lida naquela ocasião [...].

O próprio operador afirma ser "incrível" essa situação, ou seja, o fato de trabalhar na comunicação de uma instituição pública que lida com a Lei de Acesso à Informação, mas ter tido contato com o conteúdo da legislação fora do seu ambiente profissional. Ainda merece destaque a afirmação do entrevistado de que "deu uma lida" no texto da lei, mas não houve um aprofundamento na compreensão do seu conteúdo.

As entrevistas apontam que os contatos com a Lei ainda são poucos entre os operadores da comunicação, um entrevistado relatou não ter nenhum conhecimento da legislação:

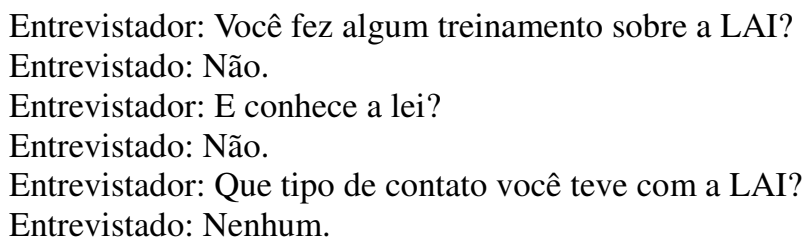

Um entrevistado chegou a dizer claramente que leu a lei somente no dia anterior à entrevista para esta pesquisa. Outro afirmou que a leu para prestar concurso público. Os demais informantes não fizeram qualquer indicação de que tenham lido a lei, mas apontaram que seu contato com ela foi principalmente por meio do site de suas instituições. Quando tabulados, os dados obtidos nas entrevistas apontam as seguintes informações:

- 18 dos 19 operadores entrevistados afirmaram conhecer a lei;

- 1 disse não saber da existência da legislação;

- 7 disseram ter conhecido a LAI por meio do site da instituição que o setor de comunicação administra;

- 2 tiveram conhecimento da lei porque foram informados que responderiam pedidos de informação no e-SIC, porém, isso não se concretizou;

- 2 disseram ter tido conhecimento a respeito da LAI, pois se relacionam com servidores do setor que opera a lei;

- 1 conheceu a LAI ao estudar para um concurso público; 
- 1 teve contato com a LAI no curso de graduação que realizou;

- 1 disse conhecer a lei, entretanto, ao tentar explicar o que é a LAI, falou de legislações sem nenhuma relação com a Lei 12.527/2011;

- 1 afirmou ter tido contato com a lei porque compôs uma comissão que se responsabilizou por publicar as informações mínimas no site da sua instituição;

- 1 trabalha informalmente produzindo respostas para o e-SIC, daí seu contato com a legislação;

- 1 afirmou saber da existência da lei, mas não tem conhecimento a respeito do que se trata;

- 1 fez o curso para operador da LAI, apesar de ser também operador da comunicação e;

- 1 assistiu à palestra sobre a lei, ofertada pela CGU.

De modo geral, os operadores da comunicação têm conhecimentos primários da lei, sabem que ela existe, sabem que serve para permitir e oferecer o acesso às informações públicas, mas param por aí. Não parece que tenham condições, ao menos a maioria deles, de fazer uma leitura crítica da lei aplicando-a às ações da comunicação. Houve exceções: 2 dos 19 entrevistados apontaram questões mais profundas a respeito da relação entre a lei e a comunicação. Afirmaram, por exemplo, que a lei não alterou suas rotinas de trabalho, pois a legislação prima pela transparência e a comunicação que esses setores praticam, segue os mesmos princípios.

Síntese dos dados levantados a respeito do nível de conhecimento da LAI:

a) Dentre os 19 operadores da comunicação que foram entrevistados, 17 não fizeram qualquer curso de capacitação sobre a Lei de Acesso à Informação;

b) Um entrevistado relatou não ter nenhum conhecimento sobre a legislação;

c) Apenas dois entrevistados foram capazes de relacionar a LAI com a comunicação, fazendo uma análise mais elaborada dessa relação.

\subsection{Categoria 2: Proximidades entre a visão dos operadores da comunicação e as normas estabelecidas pela LAI}

De acordo com Cunha Filho e Xavier (2014), a LAI se apoia nos princípios ${ }^{47}$ da:

47 Cunha Filho e Xavier (2014) definem esses princípios da LAI. De acordo com eles, a máxima divulgação das informações públicas significa que a regra é a publicidade e que o sigilo só deve existir como exceção; a desmotivação do pedido indica que o solicitante não precisa justificar para que deseja a informação, ele pode fazer o pedido sem explicar seus motivos; celeridade e facilidade do acesso indica a obrigação do Estado em atender em tempo hábil as solicitações, tanto que a lei brasileira determina que as perguntas sejam respondidas imediatamente; o duplo grau de julgamento coloca à disposição do interessado o 
1. Máxima Divulgação das Informações Públicas;

2. Desmotivação do Pedido;

3. Celeridade e Facilidade do Acesso;

4. Duplo Grau de Julgamento;

5. Universalidade;

6. Transparência Ativa;

7. Promoção de um Governo Aberto e de uma Cultura da Transparência;

8. Excepcionalidade das Hipóteses de Restrições; e

9. Proteção aos Denunciantes.

Parte desses princípios aplica-se mais ao direito e menos à comunicação, entende-se, aqui, como princípios que afetam diretamente a comunicação:

- Máxima Divulgação das Informações Públicas;

- Universalidade;

- Transparência Ativa;

- Promoção de um Governo Aberto e de uma Cultura da Transparência;

- Excepcionalidade das Hipóteses de Restrições.

Com base nesses princípios da LAI, perguntou-se aos entrevistados quais devem ser os princípios da comunicação em um órgão público.

Os 19 operadores da comunicação ouvidos dividem-se em dois grupos. No primeiro, com dois representantes, encontram-se os que defendem que a comunicação nos órgãos públicos deve seguir os mesmos princípios éticos do jornalismo, como descrito na fala seguinte:

Entrevistador: Como você entende que deve ser a comunicação em um órgão público, quais os objetivos, quais os princípios?

Entrevistado: Bom, os princípios são aqueles que a gente tratou rapidamente em

recurso, caso lhe seja negada informação, ou seja, nenhum órgão público pode negar o acesso e encerrar a questão, o cidadão sempre poderá recorrer a uma segunda instância; a universalidade indica que qualquer pessoa pode pedir informação, não há necessidade de ser brasileiro, maior de idade, ser eleitor, enfim; o princípio da transparência ativa define que o Estado deve ser proativo divulgando informações sem que existam solicitações; promoção de um governo aberto de uma cultura da transparência é o princípio que obriga o governo a promover campanhas em favor da abertura, leva o governo a agir como fomentador da transparência e não apenas como cumpridor da LAI, cabe ao governo ser um agente que leve a sociedade para mais abertura; a excepcionalidade das hipóteses de restrições coloca o Estado como obrigado a agir, de regra, liberando a informação, precisando de uma determinação legal ou constitucional que permita o sigilo; proteção ao denunciante é a garantia de que o indivíduo que trouxer a público informações sensíveis terá sua identidade preservada. 
outros momentos. Então para a área de jornalismo, por exemplo, a redação ela é restrita por lei ao profissional jornalista. Ela deve obedecer aos princípios do jornalismo e aos critérios jornalísticos. Ela precisa apresentar as notícias que estão relacionadas principalmente com relevância, abrangência, atualidade, factualidade, novidade, ineditismo e também numa escala de prioridade, uma vez que o filtro, a gente tem 14 campus e ainda a Reitoria com uma produção diária às vezes muito grande, não cabe tudo no portal principal, então precisa estabelecer um filtro e esse filtro também serve para a produção de notícia. Então, o primeiro deles é o interesse público, o segundo, o interesse comum à comunidade dos campi que estão em funcionamento e depois, por último, que é o interesse da comunidade específica de um campus. Nós também, como eu já disse, seguimos os princípios éticos, então o jornalista não submete o texto para aprovação, ele responde como autor do texto, pelo que é publicado. Não compete à instância hierárquica a definição do que deve ou não ser publicado no portal do Instituto. Nós somos jornalistas responsáveis por toda a informação que divulgamos de acordo com o código de ética da profissão e seguimos aqui com rigor a defesa pela liberdade de imprensa, pela prestação de informações importantes para as comunidades interna e externa e temos isso como uma obrigação social. É o papel do servidor, do jornalista que está no serviço público federal, prestar serviços públicos de informação. Sempre informar e brigar pela informação em prol da sociedade, é uma obrigação social.

No segundo grupo, encontram-se 17 operadores da comunicação que defendem a ideia da divulgação exclusiva das coisas boas e que adotam uma postura próxima do secretismo ao argumentarem a favor de que não sejam publicadas notícias institucionais ruins ou até mesmo que se estabeleça algum tipo de controle que não permita que as informações negativas, para as instituições, sejam publicadas por órgãos oficiais. Nesse grupo, encontra-se um operador que se queixa abertamente de subordinados que querem publicar informações negativas ou de membros da comunidade que cobram do setor de comunicação mais transparência. O modelo de produção das informações também contribui para a publicação apenas de notícias positivas. Um operador relatou que os profissionais da comunicação não têm tempo para pensar em pautas ou em matérias a serem publicadas, pois estão envolvidos no atendimento aos pedidos de produção de notícias feitos por membros da comunidade interna dos IF's. A maioria desses pedidos, aponta o entrevistado, refere-se a feitos positivos realizados por servidores que pedem a publicação. No caso dos feitos negativos, dois operadores da comunicação são taxativos ao afirmarem que, na prática, não se publica. A fala a seguir informa como ocorre esse sistema de produção de informações:

Veja, hoje em dia está diferente [...] quando eu entrei aqui na Instituição, no início a gente tinha muita dificuldade de obter informação dos setores para divulgar. Era preciso que a gente fosse aos setores perguntando: aqui tem alguma coisa para divulgar? Tem alguma coisa que gere notícia?

Então a gente bateu muita perna pela escola, durante muito tempo pra chegar ao ponto, para mudar a cultura das pessoas de verem o quanto é importante divulgarem as suas ações, então hoje que as pessoas estão nos procurando a gente não vai retroceder e dizer: não, isso aqui não é importante para divulgar. A gente estará se contradizendo até. Mas de fato [...] hoje em dia quase tudo que se publica no site 
são demandas da comunidade interna, dos diversos setores, são eles que ditam as pautas. É muito difícil a gente da comunicação definir, pensar em outras pautas, porque essas demandas já nos consomem muito o tempo e o trabalho.

Às vezes, o entrevistado defende uma comunicação transparente, mas o discurso apresenta contradições. Ao mesmo tempo em que defende a transparência, prega práticas que vão na contramão da abertura das informações. A citação seguinte dá essa dimensão. $\mathrm{O}$ operador da comunicação ressalta a necessidade de se priorizar a comunicação ativa, a disponibilização de informações e o cuidado para que a estrutura pública não seja usada de modo a gerar promoção pessoal. Contudo, ao finalizar o discurso, o comunicador afirma que se deve buscar o "bom sensacionalismo" e não se deve ir atrás de manchete. Fica clara a intenção do operador de evitar notícias negativas e apresenta-se, nesta e em outras falas de entrevistados, a ideia de que as notícias devem focar-se nas boas novidades e não no gestor, concordando com o princípio constitucional da impessoalidade ${ }^{48}$. Os operadores da comunicação veem essa publicação exclusiva de notícias positivas para a instituição como algo bom. Entretanto, tomando como norte os princípios da LAI, ao fazer a exclusão de qualquer notícia negativa ferem-se os princípios da Máxima Divulgação e da Excepcionalidade do Sigilo, além de se incorrer no risco do corporativismo ${ }^{49}$. Segue a fala do entrevistado:

\footnotetext{
Comunicação nos órgãos públicos, isso foi uma discussão bastante forte na elaboração da nossa política de comunicação. Quem é o serviço público? É aquele que presta serviço ao público e a comunicação deve atender com presteza a comunidade que impacta, deve ser transparente, deve ser ativa e, acima de tudo, sem privilégios. O jornalismo que fazemos aqui não tem o intuito de exaltar qualquer membro da gestão, qualquer cargo, qualquer pessoa, temos o intuito de mostrar o que o Instituto faz. Ninguém vai atrás de manchete, de furo sensacionalista, mas o bom sensacionalismo, mostrar aquilo de bom que ocorre na instituição.
}

Nessa próxima fala é possível observar como pensam os operadores que defendem a comunicação como instrumento de divulgação e publicação de notícias exclusivamente boas. Apesar de se autoafirmarem favoráveis à transparência, esses 17 operadores têm um discurso de que a comunicação precisa fazer uma espécie de ação propagandística da instituição, omitindo informações negativas. Eles retiram dos setores de comunicação de suas instituições qualquer responsabilidade por informar sobre questões negativas do IF e passam para a

48 A constituição brasileira, em seu Artigo 37, caput, define a impessoalidade como um princípio que deve reger a Administração Pública.

49 Bucci (2008) fala sobre o risco de a comunicação em órgãos públicos transformar-se em uma comunicação em defesa da corporação, corporativismo. 
sociedade e para o mercado de mídia a obrigação de distribuir esses tipos de informações.

O operador da comunicação em órgão público parece viver uma dualidade entre defender o patrão - no caso, o governo; ou defender o público - o cidadão. A fala de que não se vai "criticar o governo no site dele" dá a dimensão dessa dificuldade ética, pois o operador da comunicação expõe aí uma visão da coisa pública como pertencente a alguém, ao governo $^{50}$. Dessa forma, usa o argumento para se isentar de sua responsabilidade como agente cumpridor da LAI. A aplicação da Lei de Acesso à Informação acaba produzindo dilemas éticos que afetam a comunicação das instituições públicas. Seus princípios se chocam com a visão de comunicação e transparência apresentadas por 17 operadores entrevistados. Para cumprir a LAI, será necessário repensar, no contexto dos IF's, alguns conceitos do que se acostumou nomear como Comunicação Institucional ${ }^{51}$ ou Comunicação Organizacional ${ }^{52}$. A função da comunicação, para usar as palavras de um entrevistado, terá que ser repensada a partir da LAI. Sobre os princípios da comunicação em órgãos públicos, um operador disse:

São os mesmos princípios (os princípios da comunicação em órgãos públicos), são
quase os mesmos princípios que norteiam qualquer assessoria de comunicação, até a
privada. É facilitar o fluxo de informação, azeitar esse fluxo, vertical e horizontal.
Só tem uma responsabilidade que é maior porque no caso da comunicação pública
eu considero que o meu patrão é o cidadão. E isso aí na verdade quando você é
servidor público, como eu vejo, muita gente prefere essa designação, nós somos
contratados para servir mesmo. Então a responsabilidade da comunicação de um
órgão público é essa, você dar a transparência, você garantir a transparência da
informação, fazer com que ela seja clara, que ela seja precisa, porque o que está em
jogo, você está prestando contas não só a um patrão particular, a uma, duas ou três
pessoas. Você está prestando contas a uma sociedade inteira. Esse é o diferencial,
mas na essência é a mesma coisa. A função também da assessoria de comunicação
pública e privada é você prever crises, você trabalhar com prevenção, usando a
informação como prevenção, você sabe que aquilo ali é um ponto nevrálgico, uma
coisa que... você em vez de fugir daquele assunto, como trabalhar essa informação
de maneira que os danos à imagem institucional não sejam muito grandes? Porque aí
a gente trabalha para a instituição. Um exemplo claro, quando tem greve aí o
sindicato cobra, ele acha assim como você é servidor público, como se nós fôssemos
seres independentes e não devêssemos nada a ninguém e eles querem que o site
institucional faça apologia da greve. Aí eu falo assim: olha só, não é função do site
institucional fazer apologia da greve, dizer que a greve teve adesão de $50 \%$, quando
geralmente teve de $10 \%$, né, não é, pra isso vocês têm o site do sindicato.
Qual é a função do site institucional? Dizer que vai ter aula tal dia ou que não vai ter

50 Diniz (2013) define governo como "gestão”, “autoridade administrativa”, “conjunto de pessoas que exercem o poder político”. Ao definir o site da instituição como pertencente ao "governo”, o entrevistado, operador da comunicação, está fugindo do respeito à coisa pública, está colocando como pessoal algo que é de todos. Pode-se entender que o compromisso desse operador é mais com seus chefes, o governo do momento, do que com o cidadão ou com o direito à informação.

51 Rabaça e Barbosa (2001) definem Comunicação Institucional como aquela que visa a promover uma imagem favorável de determinada instituição ou órgão público.

52 Lendo Rabaça e Barbosa (2001), compreende-se Comunicação Organizacional como uma operação relacionada ao marketing e, portanto, segundo Zémor, excluída da Comunicação Pública. 
aula, prestar um serviço e não criticar e porque num sei o que. Vou criticar um gestor da instituição no site dele? Vou criticar o governo no site que é pago pelo governo? Eu sempre faço essa pergunta: você já viu alguma vez a Coca-Cola fazer uma matéria dizendo que ela faz mal para o público? Então é um pouco falta de noção, agora, não tem nada a ver com falar mentira.

A obrigação da comunicação aí, é como eu acho, qual é o meu trabalho? Dizer tudo de bom que a instituição tem para oferecer ao público, ponto. Esse tudo de bom é verdadeiro. Eu não vou dizer tudo de mal, realmente eu não vou dizer aqui no site todos os defeitos da instituição, não cabe a mim, aí cabe ao jornalista profissional que trabalha no mercado, que faz uma denúncia e aí procura a instituição e eu faço a ponte entre ele e o gestor: responde gestor, ele tá dizendo isso. Mas não é minha função.

Essa próxima fala de um operador da comunicação vai contra os princípios da LAI e, inclusive, chega a colocar o comunicador como possível cúmplice de irregularidades ao afirmar que, mesmo sabendo de erros, deve manter silêncio. O operador da comunicação é descrito como responsável por manter, primordialmente, a imagem da instituição livre de qualquer arranhão, mesmo que precise deixar de fazer a transparência ativa e omitir informações em um texto que se pretende uma notícia. A próxima fala foi a mais explícita sobre a questão, mas outras 17 seguem, em medidas diferentes, a mesma visão:

Eu acho que a comunicação nos órgãos públicos ela tem que ser pública. Pública, mas assim, a gente tem muito isso com os estagiários, por exemplo, o estagiário ele vem de um curso de jornalismo, o jornalismo hoje ele é uma profissão muito ampla e que tem uma visão muito factual e muito sensacionalista, não é que todo jornalista seja sensacionalista mas quando ele chega no órgão público ele tem essa ideia de que a notícia ela pode ser dada de qualquer jeito e eu acho que no órgão público a comunicação, a notícia, ela tem que ser mais comedida, [...]. Um evento que está acontecendo a gente não vai publicar, a gente não vai colocar tudo que aconteceu no evento, teve um problema no evento, sei lá teve um desentendimento, você vai publicar aquilo? Um jornal publica porque um jornal vende, um jornal precisa vender, mas a gente não. Eu acho que a comunicação empresarial e a comunicação pública têm dois parâmetros bem interessantes para se comparar porque eu vou [...] Eu acho que a gente precisa ter um olhar diferenciado para esse tipo de matéria, muitas vezes eu quero dizer que o que está acontecendo na instituição não é certo, mas eu posso? Eu sou comunicação da instituição, eu vou fazer uma matéria detonando a instituição? Mesmo eu sabendo, eu tendo a consciência de que aquilo ali precisa que alguém veja, que alguém reveja aquilo, que resolva aquela situação, eu não tenho como tornar aquilo público.

Dentre os 19 operadores da comunicação entrevistados, nenhum entrou em acordo com o princípio da LAI, da máxima divulgação, especialmente quando o tema é notícias. Dois operadores trataram da questão ética com muita veemência, mas, ao final do discurso, ressaltaram que essas questões da ética jornalística estão, nesse caso, sujeitas ao que poderia ser chamado de comunicação institucional, e que Bucci (2008) chamaria de comunicação corporativa.

Em um exemplo, dado por um dos entrevistados, é possível perceber a materialização 
desse dilema "LAI versus Comunicação Institucional" e que pode surgir no dia a dia da instituição. $\mathrm{O}$ entrevistado afirmou que, ao fazer a cobertura jornalística de um evento, o comunicador da instituição não deve relatar, em sua notícia, os eventuais problemas que ocorram ali. Suponha que um grupo de estudantes realize um protesto contra o gestor da instituição. De acordo com o princípio da máxima divulgação da LAI, esse protesto precisa constar da ata, ou relatório, ou qualquer outro documento que se construa sobre aquele evento. Por que então não constaria da notícia que será publicada nos veículos oficiais da instituição? Esses veículos estão fora da jurisdição da LAI? O jornalista que está ali para fazer o relato dos acontecimentos segue princípios legais diferentes do que segue um secretário que faz uma ata?

Fica claro nas falas de todos os 19 entrevistados que, para eles, os princípios da LAI não se aplicam inteiramente à comunicação. Em seus discursos, esses operadores da comunicação veem-se acima ou à parte dos princípios da Lei de Acesso à Informação. Talvez essa visão seja oriunda dos princípios da comunicação institucional que, segundo Rabaça e Barbosa (2002), têm como objetivo divulgar ações de forma a tornar aceitáveis as práticas das instituições.

Síntese dos dados levantados no tema proximidades entre a visão dos operadores da comunicação e as normas estabelecidas pela LAI:

a) 2 operadores defendem que a comunicação nos órgãos públicos deve seguir os mesmos princípios éticos do jornalismo;

b) 17 operadores da comunicação defendem a ideia da divulgação exclusiva das coisas boas nos veículos institucionais do IF;

c) $\mathrm{O}$ modelo de produção das informações contribui para a publicação apenas de notícias positivas;

d) Às vezes, o entrevistado defende uma comunicação transparente, mas o discurso apresenta contradições que o levam a negar a transparência;

f) Os operadores da comunicação veem a publicação exclusiva de notícias positivas para a instituição como algo bom. No entanto, ao fazerem a exclusão de qualquer notícia negativa, ferem-se os princípios da Máxima Divulgação e da Excepcionalidade do Sigilo;

g) Os operadores retiram dos setores de comunicação de suas instituições qualquer responsabilidade por informar sobre questões negativas do IF e passam para o mercado de mídia a obrigação de distribuir esses tipos de informações;

h) O operador da comunicação é descrito como responsável por manter a imagem da 
instituição livre de qualquer arranhão;

i) Dentre os 19 operadores da comunicação, nenhum entrou em acordo com o princípio da LAI, da máxima divulgação.

\subsection{Categoria 3: Visão dos operadores da Comunicação sobre a LAI}

Todos os 19 operadores da comunicação entrevistados veem a lei de forma positiva e entendem que existe a necessidade de se estabelecer a obrigatoriedade da divulgação das informações públicas, pois, segundo um desses entrevistados, ainda persiste no serviço público uma "postura ditatorial e autocrática" de alguns gestores. Todos avaliam, também, que a LAI contribui para a melhora do serviço prestado.

Eu acho a Lei de Acesso à Informação importante, foi uma conquista para o cidadão formalizar aquilo que a Constituição já tratava, de que todo cidadão tem o direito de obter as informações do seu interesse, no caso a lei veio regulamentar isso, essa determinação constitucional. Eu vejo como uma conquista importante do ponto de vista da transparência, do ponto de vista da necessidade de que os órgãos públicos prestem as informações de interesse público, inclusive com essa questão da transparência ativa sem necessariamente ser provocado pelo cidadão e mesmo quando provocado sem que o cidadão tenha que justificar para que ele quer essa informação. Tudo isso eu vejo como uma conquista muito grande. Talvez, assim, eu não sei em que nível os nossos gestores, e eu falo de uma forma geral, não apenas aqui do Instituto, estão preparados ou foram preparados para a Lei de Acesso à Informação porque, às vezes, os dados que a gente percebe não estão tão acessíveis, não estão tão a mão para serem informados ao cidadão, é preciso fazer uma busca, o setor precisa de um tempo para buscar essas informações que nem sempre estão em bancos de dados eletrônicos fáceis que você consulte mediante planilha, ou mediante sistema. Então, às vezes, precisa de uma busca em arquivos físicos. Por isso não sei até que ponto os órgãos públicos e os gestores dos órgãos públicos foram preparados para essa nova era que eu imagino é você ter informação acessível ao cidadão no menor tempo possível. Eu acho que algumas dificuldades de implementação da LAI que tem aí dois anos, tenha relação com isso, com essa cultura que a gente tinha ou tem nos órgãos públicos, a gente meio que tinha uma cultura do sigilo e a cultura do acesso veio com a LAI, mas para implantar essa cultura não é da noite para o dia, leva um processo.

A LAI vem exatamente no princípio da transparência. É um direito do cidadão ver onde está sendo investido o dinheiro público, ela veio para qualificar qualquer tipo de gestão.

Entrevistador: O que você pensa da LAI?

Entrevistado: É importante para a cidadania, mas o poder dela é pouco conhecido.

Na verdade, o advento dessa lei, de fato é fantástica. Eu acredito que aí é uma questão nacional, e não só uma questão da Administração Pública. Eu acho que a gente vive numa sociedade que precisa amadurecer e muitas vezes o amadurecimento esperado, como reflexões, como cumprir as leis e aí não vamos longe, até lei de trânsito às vezes não funciona apenas pela divulgação, pelo diálogo, pela sensibilização. É por isso que no Brasil ainda precisam surgir leis que 
transformem algumas questões em obrigatoriedade, que seja preciso mesmo cumprir.

Os operadores da comunicação, também foram questionados sobre quais as maiores dificuldades em se trabalhar com a lei. Obtiveram-se os seguintes resultados:

- 10 disseram não ter condições de avaliar; A justificativa para não se fazer essa avaliação é que os operadores da comunicação não têm contato suficiente com a lei.

- 3 não avaliaram; simplesmente não responderam à pergunta e não se justificaram;

- 1 afirmou que a maior dificuldade é conscientizar os gestores sobre a importância da lei;

- 4 afirmaram haver dificuldades em transformar as informações em linguagem cidadã;

- 1 afirmou que a maior dificuldade - objetiva - é a exposição dos salários dos servidores.

Um desses operadores acrescentou que há a necessidade de se trabalhar a questão tecnológica, o que significa, na visão dele, maior integração com as áreas de tecnologia da informação das instituições para buscar soluções, por exemplo, na forma como os sites se estruturam.

\begin{abstract}
Eu acredito que melhorou [a instituição com a LAI]. A análise que eu faço é que melhorou porque, primeiro, a comunidade externa e interna ela possui um canal formal onde ela pode se dirigir e fazer a sua solicitação. Como não existia esse canal formal, por exemplo, então às vezes quando era servidor interno acabava que caia não numa coisa formal parecia que alguém que me respondesse uma solicitação faria um favor de me responder, não é isso, ele tem que responder seja para o servidor interno ou o público externo. Então sobremaneira melhorou. Melhorou também até o fluxo das informações, então tem informações que existem no Instituto e que não estavam sendo sistematizadas talvez da maneira adequada, ou da melhor maneira ou também não estavam sendo sistematizadas que motivados por questionamentos do SIC a gente sabe que isso já melhorou. Está refletindo numa melhoria de processos internos, os setores estão se estruturando pra melhorar os seus processos internos e consequentemente também estarem prontos a responder às informações que nos chegam.
\end{abstract}

Síntese dos dados levantados a respeito da visão dos operadores da Comunicação sobre a LAI:

a) Os 19 operadores da comunicação veem a lei de forma positiva;

b) 4 deles afirmaram haver dificuldades em deixar as informações em linguagem cidadã;

c) 1 operador afirmou ser necessário integrar as áreas de comunicação e tecnologia da 
informação para buscar soluções para a estruturação dos sites.

\subsection{Categoria 4: Avaliação da relação entre a LAI e a Comunicação}

Se no caso dos operadores da LAI, todos dizem haver uma boa relação entre os setores, quando se fala com os operadores da comunicação, ouve-se que a relação não é tão boa. Nem todos os entrevistados foram claros ao tratarem dessa relação, deram respostas, por vezes, evasivas. Por isso, foi necessário classificar as falas entre os que consideram a relação suficiente, não suficiente e os casos em que não foi possível avaliar a resposta.

Assim, considera-se que 13 dos 19 entrevistados tratam a relação entre os dois setores como insuficiente. Nesse grupo, foram inclusos não apenas as falas que afirmaram categoricamente que a relação não é suficiente, mas também os que dizem haver uma relação razoável, mas não ideal.

Dentre os operadores, 3 falaram de forma que foi possível concluir que consideram a relação boa o suficiente. Nesses casos, os entrevistados não fizeram ressalvas, apenas emitiram falas positivas sobre a relação entre os dois setores.

Em três casos, não foi possível avaliar porque o entrevistado sequer sabia da existência da LAI ou porque tratou de outro assunto e não emitiu juízo de valor sobre a relação.

Nessa avaliação da relação, há casos em que o entrevistado foi cauteloso na resposta, porém, fez outras afirmações que permitiram avaliar. Na fala seguinte, o operador elogia essa relação com o setor da LAI, ele foi o único a fazer isso:

Entrevistador: Como está a relação entre o setor da LAI e o da comunicação? Entrevistado: Existe uma boa interação, a gente tem uma proximidade interessante com o setor da Lei de Acesso à Informação [...].

Um exemplo do distanciamento entre os setores foi exposto por um operador da comunicação que nem mesmo esperou que se terminasse a pergunta e afirmou logo sua pouca relação com a lei e, consequentemente, com o setor que a operacionaliza na instituição. Como apontado pelos operadores da LAI, os dois setores não se relacionam.

Entrevistador: Sobre a LAI...

Entrevistado: Eu já posso até te responder que hoje o contato que eu tenho é através do site, que nós temos linques específicos que são obrigatórios em função dessa lei, mas não fui eu que implementei essas coisas no site, elas já vieram do site anterior e nós só mantivemos no site novo. 
Os operadores da LAI veem a comunicação como uma espécie de assistente de divulgação, em que eles solicitam uma tarefa burocrática como a publicação de uma informação no site, e a comunicação executa. Já a comunicação parece entender o setor da LAI como algo distante da sua realidade, ou seja, o trabalho de disponibilização de informações feito pela LAI não seria tema para o setor de comunicação.

Síntese dos dados levantados sobre a avaliação da relação entre a LAI e a Comunicação:

a) 13 dos 19 entrevistados tratam a relação entre os dois setores como insuficiente;

b) Os operadores da comunicação não veem a LAI como um tema pelo qual o setor de comunicação deva ser responsável.

\subsection{Categoria 5: Mudanças influenciadas pela LAI}

Para a maioria dos operadores da comunicação, 10 de um total de 19, a implementação da LAI não causou mudanças no trabalho que desenvolvem; já 7 disseram que houve mudanças; 2 afirmaram não ter condições de avaliar, pois não estavam na instituição antes de a lei entrar em vigor.

Um entrevistado, que indicou não ter havido mudanças na comunicação a partir da LAI, tem a percepção de que não havia o que mudar, pois a lei não trouxe novidade específica para o trabalho realizado pelos setores da comunicação:

\footnotetext{
Entrevistador: no seu ponto de vista, a entrada em vigor da Lei de Acesso à Informação alterou de alguma forma o trabalho do setor de comunicação?

Entrevistado: Não. Porque o setor de comunicação do Instituto Federal, que existe com uma jornalista desde o ano de 2008 - antes disso, eram profissionais que não eram da área de comunicação com formação superior - ele já atende aos requisitos do jornalismo pela qualidade da informação, pela clareza, correção, completude, pelos princípios éticos que envolvem, pela questão do interesse social. Os textos, aqui, eles não são submetidos pra aprovação de nenhum gestor, justamente porque são critérios de noticiabilidade técnica e que a gente segue a legislação da área para a produção disso.
}

Se nessa fala se entende que a LAI não mudou a comunicação, já que não havia o que mudar, na próxima, outro operador atribui essa falta de mudança a uma ausência de ligação entre os setores da LAI e da comunicação. As duas áreas são vistas, por ele, como temas distintos. A manifestação abaixo é de um entrevistado que segue na direção de apontar que a única mudança veio com os linques obrigatórios estabelecidos para os sites dos IF's e que a LAI não tem relação com o setor de comunicação. 
Entrevistador: A LAI alterou de alguma forma o trabalho do setor de comunicação? Entrevistado: Não, em nenhum momento. Eu poderia ter sentido alguma dificuldade, por mais que eu tenha entrado e a lei já estava estipulada e os linques obrigatórios já estavam determinados dentro do site [mas] ela não me causou nenhum problema até hoje.

Entre os 19 operadores, 9 apontam como única mudança na comunicação a inserção da parte de transparência ativa nos sites das instituições. Mesmo assim, o trabalho parece ser feito de forma automática, como se o setor de comunicação, quando solicitado, apenas subisse a informação para o site, sem pensar em trabalhá-la.

Entrevistador: No seu ponto de vista, a entrada em vigor da LAI, alterou de alguma forma o trabalho da comunicação?

Entrevistado: Olha, eu te diria que alterou, mas pouca coisa. Foi mais assim, no momento de implantação da Lei que a gente teve que fazer o menu, adaptar o site para cumprir os requisitos da lei, criação de menus, de todos aqueles submenus recomendados pela CGU, colocação de banner e a divulgação inicial da Lei de Acesso à Informação. Depois que a lei entrou em vigência, tem a questão da alimentação desses dados, apesar de que isso já é meio automático, tem uma gestora da LAI aqui no Instituto, que não trabalha na comunicação. Na verdade a gestora da LAI aqui no Instituto é a ouvidora geral e aí ela meio que monitora a alimentação desses dados da Lei de Acesso à Informação; e tem alguns setores que até já enviam os dados direto para a equipe do portal, no caso a equipe do portal fica na Diretoria de Gestão e de Tecnologia da Informação. Então, por exemplo, alguns dados sobre contratos e convênios ou orçamento são enviados diretamente para a equipe do portal para que seja alimentado de acordo com o que a lei pede.

Um operador deixou transparecer o que se entendeu como um problema: apesar de afirmar que a LAI não trouxe mudanças, pois a comunicação já fazia um trabalho compatível com os princípios da Lei. Ele disse que era priorizado pela comunicação determinado tipo de informação. O problema que se encontra aí é que as informações que ele considera prioritárias não são as únicas consideradas preferentes para a LAI. Ou seja, a definição do que seria uma pauta prioritária para o operador da comunicação não engloba todas as pautas prioritárias para a LAI.

Entrevistador: Você acha que a LAI alterou alguma coisa no trabalho do setor de comunicação?

Entrevistado: Eu não percebi nenhuma mudança não. Essa questão de você disponibilizar informação melhor possível, maior quantidade possível para o cidadão, é uma preocupação que a gente já tinha, sempre. Já faz, eu não sei em que ano foi que o Instituto, na época ainda Cefet, lançou seu primeiro portal. De lá pra cá a gente sempre tem a preocupação de, principalmente assim, a informação que o nosso público demanda mais é pelos processos seletivos. Hoje em dia a gente tem do [curso] técnico à pós-graduação, então as pessoas querem saber sobre os exames, basicamente isso. A maior parte da demanda é dos processos seletivos, então nós tivemos o cuidado de na nossa página ter essas informações e sempre que chega pra gente, a gente disponibilizar logo. 
Um entrevistado afirmou não ter ocorrido mudança nenhuma, porém, não atribui isso ao fato de a comunicação já agir de forma a estar adequada aos princípios da LAI, mas ao fato de a comunicação não responder perguntas enviadas pelo e-SIC, ou seja, a LAI é vista pelo operador da comunicação apenas pelo lado da transparência passiva. Ele atribui à lei funções relacionadas a outro setor e não vê a nova legislação como também aplicável à comunicação, conforme resposta abaixo:

Entrevistador: Em relação à Lei de Acesso à Informação, no seu ponto de vista, ela alterou em alguma coisa o trabalho da comunicação?

Entrevistado: Em nada. Até porque assim, no início existia uma orientação de que todos os processos referentes a essa lei, eles seriam dados entrada no próprio site, no sistema, a comunicação da Reitoria faria essa distribuição para as coordenações de comunicação social dos campi, ela recebia e ela distribuía. Eu ainda cheguei a receber uns quatro ou cinco processos. Aí a gente entrava em contato [...] chegava aqui na comunicação, a gente via o que era, via para quem dirigir, fazia o encaminhamento, definia o prazo em que teria que ser devolvido, eles devolviam para a gente e a gente devolvia para a comunicação da Reitoria, mas já tem muito tempo que não passa nada por aqui.

Foi possível perceber nas entrevistas que, se não houve mudança no trabalho da comunicação, essa ocorreu na visão que os operadores têm a respeito da instituição. Isso foi percebido no relato de três entrevistados, o que me faz supor que a LAI levou para esses comunicadores mais informações.

Entrevistador: A LAI mudou alguma coisa na comunicação?

Entrevistado: Eu acho que da importância das informações, não sei qual o termo usar, mas essas informações institucionais [...] desse mundo assim que às vezes você não se atenta. Como comunicador da instituição muitas vezes você fica naquele [...] não sei se comodismo, enfim naquela coisa de divulgar, aconteceu tal evento, olha está aberto tal processo seletivo, não sei o que e tal. Mas tem um mundo envolvido nisso de [...] um mundo político também né, de documento, de tudo que às vezes você [...] Com a LAI, eu percebo que eu comecei a ficar mais por dentro da instituição em si. Porque os pedidos vão fazendo com que você conheça melhor a instituição, você vai entendendo que existe um documento anual que tem todas as informações, que existe um boletim de serviço mensal que ali estão todas as portarias.

Entrevistador: Como você acha que a LAI interferiu na Comunicação?

Entrevistado: Eu acho que sim. Pra começar, a gente passa a entender melhor a instituição. Porque eu não sei se acontece em outros institutos, mas aqui, na comunicação social, no que depender da vontade do gestor de comunicar, nós somos os últimos a saber. Isso é uma queixa que todos, quando a gente se reúne, os assessores dos Institutos, isso é uma queixa geral, as pessoas procuram a comunicação social para as coisas mais bestas, para aquelas coisas que não são tão importantes, não são tão estratégicas. "Ah, vem cá, chegou uma pessoa tira aqui uma foto para fazer uma noticiazinha, fulano vai ter um cerimonial numa colação de grau, quem vai fazer, fulano vê se consegue botar uma notinha aî".

Mas as coisas que são importantes, que a gente tem que saber previamente, pra filtrar, pra saber em que terreno a gente tá pisando, é muito ruim você lidar com 
informação sem saber com quem você está falando, o que aquela pessoa é no jogo do bicho, se você for uma pessoa trabalhadora e a gente aqui é, a gente fica na nossa sala fazendo os textos, fazendo tudo, a gente corre o risco de [...] as informações que não são passadas pra gente porque as pessoas acham que jornalista é fofoqueiro, tem essa mentalidade errada, ele não sabe que o jornalista é quase igual padre, a gente divulga aquilo que, no caso do jornalista institucional, a gente divulga aquilo que é pra divulgar, o que é de interesse da instituição. Não trabalho no Jornal do Brasil, nem no O Globo ou na Veja. Então é uma tarefa árdua convencer o gestor que a gente está do lado deles, que a gente está pra ajudar, pra facilitar o fluxo e o que acontece?

Muitas vezes a gente recebe uma ligação de fora que diz: "ah, a gente soube que vai construir um novo campus em tal lugar." E a gente aqui responde "hã?" "Ah, eu soube que vai trocar o pró-reitor tal e vai entrar fulano". Enquanto nós deveríamos ser os primeiros a saber. Isso não é uma questão só minha, é de todo jornalista que trabalha em comunicação.

Nesse sentido, à medida que você começa a receber demandas [da LAI] e tem que manipular as respostas das pessoas àquelas demandas você acaba conhecendo um pouco mais das entranhas da instituição através do serviço. Nesse sentido eu achei ótimo. O que tá pegando? Uma hora vai chegar aqui. Alguém vai ligar, alguém vai reclamar, alguém vai pedir alguma coisa, entendeu? Algumas coisas, não é que a gente saiba de tudo. A única maneira que a instituição chega de forma privilegiada à comunicação é através da LAI. É o único fluxo direto que a gente garante, primeiro vai passar por aqui. Então nesse sentido eu achei ótimo.

Nas entrevistas, perguntou-se, ainda, se os operadores da comunicação achavam que, com a entrada em vigor da LAI, o trabalho no setor de comunicação deveria mudar. Dos 19 entrevistados, nenhum indicou que deveria haver qualquer mudança no trabalho da comunicação. Entretanto, todos entendem que deveria ocorrer uma maior proximidade do setor da LAI com o da comunicação.

\footnotetext{
Entrevistador: Você acha que a LAI deveria ter alterado em alguma coisa a comunicação?

Entrevistado: Não. Na comunicação do Instituto eu vejo que não, porque aqui os assuntos têm um trato jornalístico, não há formas de censura, não se pede para que tal assunto não seja publicizado, não seja divulgado. Desde que eu estou aqui isso não aconteceu. Talvez, claro, como toda instituição onde existe uma assessoria de comunicação, você pode discutir formas de tratar aquele tema, qual é a maneira mais necessária de fazer sobre isso, mas não há uma supervisão, não há uma questão de censura mesmo. Porque a produção e a divulgação aqui no Instituto ela é livre, pautada pela veracidade dos fatos, pelo interesse público, pela obrigação ética do jornalista que tem por base defender a liberdade de imprensa. Além das informações que são prestadas pelas organizações públicas que aqui no Instituto a gente sempre tratou isso como obrigação social. Então nós aqui sempre fizemos uma prestação de serviço público à sociedade.
}

Como se pode observar, na visão dos operadores da comunicação, a LAI trouxe poucas mudanças no seu modo de trabalhar, e eles entendem que a lei não foi feita para mudar a comunicação.

Síntese da visão que os operadores da comunicação têm sobre possíveis mudanças trazidas pela LAI: 
a) Relatos de que passaram a encontrar informações com mais facilidade;

b) Passaram a conhecer melhor sua instituição;

c) Ampliou a consciência dos operadores da comunicação quanto às disputas de poder dentro das instituições;

d) Apontam como única mudança trazida pela LAI, o acréscimo de uma sessão no site;

c) 10 de um total de 19 entrevistados não conseguiram ver qualquer mudança na comunicação da instituição;

f) A definição do que seria uma pauta prioritária para o operador da comunicação não engloba todas as pautas prioritárias para a LAI.

\subsection{Categoria 6: Visão dos operadores da Comunicação sobre a transparência ativa}

Enquanto os operadores da LAI se dividem quanto à clareza das informações da transparência ativa, se são ou não claras, os operadores da comunicação são unânimes em afirmar que não são. Um operador apontou que seria impossível para qualquer setor de comunicação tratar todas as informações da Instituição e deixá-las compreensíveis. A sugestão que ele dá é que a informação deve ser adequadamente tratada no momento da produção, ou seja, as pessoas que escrevem deveriam mudar sua forma de escrever, construindo textos mais simples. Os operadores da comunicação queixaram-se de que, algumas vezes, nem eles conseguem entender os documentos que, em tese, deveriam ser simples como, por exemplo, os editais para seleção de estudantes. Muitas vezes, disse um operador, é necessário entrevistar quem elaborou o edital para que explique o que aquele documento quer dizer.

Entrevistador: Você entende que algo deve ser mudado nessa linguagem?

Entrevistado: Desde o início, desde o seu papel. Eu sou uma defensora disso, mas é como pedir para um advogado que não fale direitês. A gente está agora fazendo o PDI, o Plano de Desenvolvimento Institucional, e eu sou da comissão de logística que vai cuidar do texto final, aí é sempre uma briga danada. Eles falam assim "porque esse é um documento técnico" e eu digo "gente, um documento técnico não significa que ele tem que ser ininteligível". Você tem duas palavras, docente e professor, porque você vai usar docente se significa a mesma coisa? Se professor comunica muito mais do que docente. Pra que? Mas é chover no molhado.

As pessoas entendem que quando você fala como todo mundo, você está empobrecendo, e eu digo, os melhores textos, dos melhores autores, você pega o melhor escritor que tem e eles escrevem fácil, eles comunicam. Então isso daí é uma luta, isso não depende da gente porque a gente não manda em nada.

Entrevistador: Seria uma alteração na fonte?

Entrevistado: Eu acho que é da cabeça das pessoas, na fonte. Já pensou se a gente tiver que traduzir tudo? Eu acho que não é necessário. Acho que as pessoas têm que ter a consciência e deixar de lado o seu jargão e lembrar que quem tá te lendo é a dona Maria ali da frente. 
Perguntou-se aos operadores da comunicação se eles produziam matérias sobre informações como prestações de contas. Todos os entrevistados responderam que sim, entretanto, pôde-se notar, nas respostas, que as notícias, muitas vezes, serviam como propaganda da gestão da instituição e não como informação clara e objetiva da situação.

Todos os que informaram produzir notícias sobre prestações de contas indicaram que os dados negativos não eram publicados nas matérias. Um operador afirmou que se sentia "triste" porque muitos projetos eram anunciados e publicavam-se matérias de que seria efetivado, mas nunca saíam do papel. Ao ser questionado se, ao fazer as notícias sobre as prestações de contas ao final do ano ou ao final de uma gestão, era informado ao leitor que determinadas metas não foram cumpridas, o comunicador respondeu simplesmente que seu trabalho ali não era esse, não lhe cabia dar "notícias negativas".

Muitos operadores da comunicação informaram que são feitas revistas, jornais ou outros tipos de materiais específicos para falar dos feitos da gestão, ao que eles dão o nome de prestação de contas. Todavia, nessas "prestações de contas" só se publicam as "boas notícias".

\begin{abstract}
Entrevistador: Vocês chegam a produzir matérias sobre prestações de contas ou orçamento?

Entrevistado: Sim. Principalmente a revista ela tem um caráter bem de prestação de contas, mas não são apenas matérias financeiras de orçamento. São matérias para mostrar as realizações que foram feitas ao longo do ano, por isso que ela é anual, ela tem um caráter bem de prestação de contas. Tem matérias sobre os eixos temáticos que tem a ver com os setores sistêmicos da Instituição e tem páginas para cada campus. Então, por exemplo, a sessão que fala de administração e planejamento normalmente ela faz um balanço do orçamento e tal, né, quanto foi investido e, muitas vezes, outros setores também. Algumas matérias desse tipo, muitas vezes com um destaque, as grandes realizações do ano, algumas vezes têm entrado prestações de contas também. Teve uma matéria na revista passada sobre assistência estudantil que tinha um gráfico explicando como tinha sido dividida a verba da Assistência Estudantil para quais modalidades de auxílio tinha sido aplicada, agora não são todas as matérias, algumas têm esse caráter mais de falar dos dados financeiros e esse caráter de prestação de contas, de mostrar as realizações, tanto no âmbito das unidades estratégicas da Reitoria quanto de cada campus que permeia a revista.
\end{abstract}

O princípio da impessoalidade não é utilizado no momento de se fazerem essas matérias que os operadores da comunicação chamam de prestação de contas. Esse princípio constitucional determina que as publicações dos órgãos públicos não podem beneficiar agentes públicos. Entretanto, a fala do próximo entrevistado deixa claro que, ao se decidir por fazer uma matéria de prestação de contas, um servidor público acaba sendo beneficiado. 
gerar uma matéria para que as pessoas entendam como estão sendo geridas essas obras dentro da instituição. E foi uma matéria que gerou um retorno positivo muito grande para a gestão do reitor, foi muito legal essa matéria. Então, assim, quando há necessidade, quando se tem uma demanda do público externo ou interno, porque a gente tem que lidar com os dois, diversos nichos de públicos que a gente tem aqui, quando há uma demanda por um desenvolvimento maior em cima de um ato da reitoria, de um documento, uma determinação da reitoria, nós pegamos a nossa parte de assessoria, vamos até a fonte que nos vai dar o desenvolvimento daquela informação e fazemos uma matéria para o site.

Todos os operadores da comunicação entrevistados afirmaram que nunca fizeram matérias sobre temas como licitações e contratos e entendem isso como natural, pois tratar-seia de outro tipo de informação que é técnica e deve ser administrada por outro setor. Dois comunicadores, entretanto, questionaram esse fato de que não publicariam matérias sobre esses assuntos ao alegarem que, quando elaboram notícias sobre uma nova obra que está sendo lançada e informam seus valores e custos, estão publicando a respeito do orçamento da instituição e, consequentemente, sobre licitações e contratos.

Síntese dos dados levantados a respeito da visão dos operadores da Comunicação sobre a transparência ativa:

a) Os operadores da comunicação são unânimes em afirmar que as informações da transparência ativa não são claras;

b) Um operador sugeriu que a solução para a falta de clareza nas informações publicadas é que sejam escritas de forma mais simples;

c) Todos os que informaram produzir notícias sobre prestações de contas indicaram que os dados negativos são publicados nas matérias;

e) Todos os operadores da comunicação entrevistados afirmaram que nunca fizeram matérias sobre temas como licitações e contratos.

\subsection{Categoria 7: Estrutura física e de pessoal da comunicação}

Se as estruturas físicas e de pessoal da LAI apresentaram-se de forma modesta, as estruturas dos setores de comunicação, por outro lado, mostram-se mais robustas. No que se refere às rotinas e processos, a comunicação também está à frente dos setores da LAI. Primeiramente, é preciso enfatizar que nas instituições nas quais se realizaram as entrevistas, verificou-se a inexistência de uma tradição de assessorias de comunicação. Essas instituições não contavam com um setor de comunicação ou com profissionais dessa área, contratados, até a criação dos Institutos Federais em 2008. Um entrevistado detalhou essa situação. 
O Instituto não tem uma cultura de contratar jornalista não, começou de uns cinco, seis anos pra cá, nós não tínhamos nenhum jornalista de cargo. [...] Não tínhamos ninguém na área de comunicação até uns cinco ou seis anos atrás [...].

Apesar de algumas das instituições que compõem a Rede Federal serem centenárias, de forma geral, eram inexistentes os setores de comunicação. Porém, como relatado pelo entrevistado, por volta de 2009, iniciou-se a estruturação das assessorias de comunicação nessas escolas. A estruturação da LAI começou em 2012, portanto, apenas três anos depois. Considerando a idade das instituições, mais de cem anos, essa diferença de tempo entre a implantação da Lei de Acesso à Informação e a implantação da comunicação pode ser considerada pequena.

Foram entrevistados 19 operadores da comunicação que fazem parte de 13 instituições e levantou-se que há, aproximadamente, 131 profissionais da área de comunicação atuando nessas instituições, entre jornalistas, relações-públicas, publicitários, redatores, programadores visuais e diagramadores. Os números podem ser maiores, pois os entrevistados não ofereceram dados exatos devido à descentralização da comunicação em determinadas instituições. Mesmo assim, a diferença entre os setores da LAI e os da comunicação, quando o assunto é recursos humanos, é gritante.

Nas 13 instituições onde foram entrevistados operadores da LAI, não foi encontrado nenhum servidor que estivesse atuando exclusivamente com a lei, ao passo que nas 13 instituições em que foram entrevistados operadores da comunicação, havia ao menos 131 funcionários dedicados, exclusivamente, à comunicação. Vale ressaltar que não estão incluídos nessa conta os estagiários, os terceirizados e os servidores administrativos que trabalham nos setores de comunicação, mas não são profissionais com perfil técnico da área de comunicação. Verificou-se, também, a existência de trabalhadores da área de comunicação atuando em outros setores. Desse modo, o número de funcionários tende a ser maior.

Quanto à estrutura física, ao contrário da LAI, todos os setores de comunicação têm espaços físicos próprios, mas os operadores da comunicação, em sua maioria, os de 10 instituições de um total de 13, consideram que o espaço físico é insuficiente. Um dado que pode explicar essa questão é que quase todas as reitorias funcionam em prédios provisórios, geralmente alugados e ainda não contam com instalações adequadas.

Quanto às rotinas e processos produtivos, todos os entrevistados indicaram que a comunicação já os tem definidos. Duas instituições têm até mesmo uma política de comunicação estabelecida em documentos oficiais. O que se pôde observar é que a comunicação está com suas rotinas bem-estabelecidas, mesmo nos locais onde o entrevistado 
diz que não estão oficializadas. Os jornais e revistas impressos têm periodicidade definidas e os sites são atualizados de acordo com as regras do jornalismo, ou seja, os fatos vão sendo captados e transformados em notícias. Existem parâmetros de funcionamento técnico para as assessorias.

Síntese dos dados levantados a respeito das estruturas físicas e de recursos humanos nos setores de comunicação dos IF's:

a) Se as estruturas físicas e de pessoal da LAI apresentaram-se de forma modesta, as estruturas dos setores de comunicação, por sua vez, mostram-se mais robustas;

b) Todos os setores de comunicação têm espaços físicos próprios;

c) 10 entre 13 entrevistados consideram que o espaço físico da comunicação é insuficiente;

d) Existem parâmetros de funcionamento técnico para as assessorias. 


\section{Conclusões}

O objetivo geral desta pesquisa foi analisar o processo de implementação da Lei de Acesso à Informação nos Institutos Federais de Educação, Ciência e Tecnologia (IF's). Para organizar o trabalho, as ações foram divididas em seis objetivos específicos, que estão expostos no Capítulo 2. No processo de realização da pesquisa de campo, para atingir esses objetivos, dividiu-se o estudo em duas partes: na primeira, buscou-se entender a relação entre os operadores da lei e a LAI; na segunda parte, tentou-se compreender o relacionamento dos operadores da comunicação com a Lei de Acesso à Informação. Cada uma dessas duas partes foi dividida em sete categorias. As conclusões estão organizadas a partir do que se encontrou em cada uma dessas categorias e, quando foi pertinente, colocaram-se lado a lado dados similares dos operadores da LAI e dos da comunicação.

Os 32 entrevistados para esta pesquisa afirmam que a LAI é positiva. Porém, os operadores da lei consideram que existe uma carência de mão de obra para lidar com sua aplicação. Um entrevistado apontou que em seu instituto já é possível ter essa avaliação de que falta mão de obra, mas ressalvou que, no momento em que a lei foi implantada, ainda não se tinha como mensurar qual seria a demanda exata de trabalho. Entende-se que, pelo fato de os Institutos Federais ainda estarem em um momento inicial da implantação da lei, essa falta de servidores é normal. As instituições ainda precisam de mais algum tempo para definir qual o tamanho exato da equipe necessária à aplicação da LAI e providenciar os servidores para executar o trabalho. Ainda nessa visão que os operadores da lei têm sobre ela, um entrevistado disse ter percebido que a nova legislação causou um aumento de trabalho em todos os setores do Instituto. Essa alteração ocorreu, segundo ele, porque toda a forma como as informações são organizadas precisa ser repensada, tendo a transparência como objetivo. Parece-me que essa mudança na forma de se fazer o trabalho do dia a dia vai exigir muito tempo, pois se trata de uma mudança cultural mais profunda no âmbito das perspectivas que orientam as práticas institucionais, e não apenas de meras alterações nos processos burocráticos. O servidor público precisa mudar a maneira como vê a sua função, o serviço público em si e a própria sociedade. Tal questão vai além das ações executadas como trabalho, trata-se da visão de mundo do servidor que precisará deixar a cultura do segredo, apontada por Jardim (1999), e aceitar, abraçar e praticar a cultura da transparência, como recomendam as cartilhas da CGU.

Ao verificar como os Institutos Federais estão implantando a LAI, descobriu-se que a administração da transparência passiva ocorre de maneira centralizada e descentralizada por setores. O modelo de centralização e descentralização também ocorre por campus. Na 
centralização que envolve os campi, apenas um operador, que fica na Reitoria, recebe as perguntas e as envia para o servidor que tem a resposta. Na descentralização por campus, cada um dos campi da instituição tem um operador da LAI ou um servidor que vai atrás das respostas. Percebo que o modelo de administração da transparência passiva que se mostrou mais adequado foi o descentralizado por campus, no qual apenas o operador da Reitoria tem acesso ao sistema e-SIC. No caso em que há um operador do e-SIC em cada campus, falta quem controle as respostas e os prazos. A demanda de trabalho, quando se trata da transparência passiva, é pequena em todos os IF's, o que permite uma centralização na Reitoria que facilita a execução e o controle do trabalho.

A etapa mais complexa desta pesquisa foi compreender o processo de implantação da parte de transparência ativa. Nenhum dos 13 operadores da LAI entrevistados apontou a existência de controles formais sobre as rotinas ou processos administrativos da transparência ativa. Mesmo sem rotinas formalmente estabelecidas e indicadas claramente pelos entrevistados, foi possível identificar, em suas falas, processos que dizem respeito à produção e publicação das informações da transparência ativa nos sites dos Institutos estudados. Concluiu-se, assim, que as únicas formas de acompanhamento da atualização das informações estão relacionadas com a descoberta, ao acaso, de erros pelos próprios funcionários, pelas verificações feitas sem periodicidade, ou quando ocorre a reclamação de um usuário. Foram apontados como responsáveis por colocar as informações da transparência ativa nos sites: os setores de tecnologia da informação, os setores de comunicação, o próprio gestor da LAI e, inclusive, em um instituto, chegou-se a dizer que qualquer pessoa que tenha a senha de acesso ao site da instituição pode publicar. Provavelmente, a dificuldade de compreender a transparência ativa vem da sua desorganização generalizada nas instituições pesquisadas. A ação da CGU, de emitir orientações, determinando quais informações deveriam, obrigatoriamente, ser publicadas nos sites das instituições, foi essencial para que se tenha ao menos parte dos dados disponíveis ao público. Entretanto, os institutos ainda precisam realizar muitas ações para que a transparência ativa seja, pelo menos, razoável.

Os problemas encontrados na transparência ativa podem ser explicados, em parte, pela falta de recursos, tanto humanos como físicos. Dos 13 operadores da LAI entrevistados, 12 informaram que não existe uma sala de trabalho exclusiva para o setor da LAI. Os espaços são divididos com outros setores. As entrevistas indicaram que as estruturas físicas da LAI não atendem a todas as determinações da lei, entretanto, 7 dos 13 operadores da lei consideram essas estruturas boas. Nenhum operador dedica-se exclusivamente ao trabalho com a lei, 
acumulando várias funções. É necessário pensar ações para a implantação da LAI. O que se tem hoje são servidores que apenas executam medidas determinadas pelo sistema e-SIC ou pela CGU. Por falta de estrutura, os setores da LAI nos Institutos não têm ações planejadas, não há reflexão sobre como melhorar a aplicação da lei. Se as estruturas físicas e de pessoal da LAI apresentaram-se de forma modesta, as estruturas dos setores de comunicação, por outro lado, mostram-se mais robustas. Todos os setores de comunicação das instituições pesquisadas têm espaços físicos próprios. Apesar disso, 10 entre 13 entrevistados consideram que o espaço físico da comunicação é insuficiente. Se faltam parâmetros para o setor da LAI organizar, planejar e controlar a transparência ativa, no caso dos setores da comunicação existem parâmetros de funcionamento técnico.

Quando se começou a pensar esta pesquisa, a meta maior era entender em que a Lei de Acesso à Informação iria ou poderia influenciar a comunicação praticada nos órgãos públicos. Intuiu-se, ao ver o texto da lei, que ele se relaciona com a comunicação, pois trata da administração e também da distribuição de informações públicas e as assessorias de comunicação de órgãos públicos lidam exatamente com isso. Na busca por compreender essa relação e, ao observar que a LAI tem a vertente da transparência ativa, imaginou-se que aí estaria o melhor ponto para compreender a relação entre LAI e a comunicação, pois a comunicação é uma espécie de transparência ativa. As assessorias de comunicação divulgam informações de forma proativa.

Entretanto, ao observar a aplicação da lei no cotidiano dos institutos, percebeu-se que o conceito de transparência ativa não estava totalmente delineado para os operadores da LAI e tampouco para os da comunicação. Nas entrevistas, todos os operadores da LAI e a maioria dos da comunicação conseguiram definir o que é transparência ativa, utilizando o conceito que a própria lei estabelece, mesmo os que informaram ter pouco conhecimento da legislação. Porém, apesar de conseguirem expressar o que seria a transparência ativa, não se conseguia explicar como ela funcionava na prática. Mesmo os operadores da LAI, que são os responsáveis diretos por fazer a transparência ativa funcionar, têm dificuldades de apontar práticas dessa transparência, de desenhar processos, indicar políticas ou mostrar as ações de transparência ativa que estavam realizando. O foco da LAI, tanto para os operadores da lei quanto para os da comunicação, parece mesmo ser, nesse momento inicial da implementação, a transparência passiva.

Com objetivo de entender como está a relação entre os operadores da LAI com a comunicação, e dos operadores da comunicação com a LAI, descobriu-se que todos os 
operadores da lei entrevistados entendem haver uma boa relação entre os dois setores. Apesar de afirmarem a existência dessa boa relação, pôde-se verificar que ela ocorre sem nenhuma institucionalização. Todos os entrevistados informaram que não são realizadas reuniões periódicas entre os setores da LAI e da comunicação. Dos 13 operadores da LAI entrevistados, 12 informaram que nem mesmo uma única reunião ocorreu entre esses dois setores desde que a lei foi implementada. Quando se analisou a relação a partir do ponto de vista dos operadores da comunicação, descobriu-se que 13 dos 19 entrevistados tratam a relação entre os dois setores como insuficiente e entendem que a LAI não é tema para o setor de comunicação. Concluiu-se, assim, que a relação entre LAI e comunicação e entre os setores da LAI e da comunicação não é integrada. Não há diálogo, não existe uma institucionalização das relações, que ocorrem de maneira informal, baseadas, primordialmente, em interações pessoais entre os operadores. Por fim, os setores não conseguem nem mesmo olhar um para o outro, são incapazes de entender como o outro funciona.

Apesar de haver esse distanciamento entre os setores da LAI e da comunicação, os operadores da lei percebem que existe similaridade entre os objetivos dos dois setores. Os 13 operadores da LAI concordam que os trabalhos realizados pelos setores de comunicação devem ser considerados uma forma de transparência ativa. Três operadores da LAI chegam ao ponto de afirmar que transparência ativa e comunicação são a mesma coisa. Entretanto, eles apontam diferenças entre os objetivos da LAI e os da comunicação. Dez operadores da lei entendem que a missão da comunicação no IF é realizar divulgação, falar apenas de coisas boas e que a comunicação não tem, nem precisa ter, um compromisso com a transparência semelhante ao que a LAI tem. Os operadores da comunicação concordam com os operadores da LAI e têm a mesma visão sobre seu papel na instituição. Dezessete operadores da comunicação defendem a ideia da divulgação exclusiva das coisas boas nos veículos institucionais do IF. Até mesmo a forma como a produção das informações é organizada no setor de comunicação contribui para a publicação apenas de notícias positivas e a omissão de qualquer informação de cunho negativo. Os operadores da comunicação retiram de seus setores qualquer responsabilidade por informar sobre questões negativas do IF e passam para o mercado de mídia a obrigação de distribuir esses tipos de informações. Todos os que informaram produzir notícias sobre prestações de contas indicaram que os dados negativos não são publicados nas matérias. Conclui-se que, tanto para os operadores da comunicação quanto para os da LAI, o setor de comunicação não deve pautar seu trabalho pelos princípios 
da Lei de Acesso à Informação. Entende-se que, quando um veículo de comunicação institucional aborda apenas fatos positivos e passa a omitir dados negativos de uma instituição, o princípio da Máxima Divulgação, da Lei de Acesso à Informação, está sendo violado.

A maioria, 11 de 13 operadores da LAI, avalia que a linguagem usada na publicação de informações da transparência ativa não é clara, porém, 2 operadores disseram que as informações dos relatórios feitos pelos auditores são claras e compreensíveis. Os operadores que afirmaram que a linguagem é clara estão ligados à área de auditoria. Já os operadores com formação nas áreas de informática ou de comunicação reclamaram das prestações de contas, apontando-as como não compreensíveis. Todos reconhecem, no entanto, que, em algum grau, há dificuldade do cidadão em lidar com a massa de informações técnicas da transparência ativa. Os operadores da comunicação são unânimes em afirmar que as informações da transparência ativa não são claras. Essa situação parece indicar, claramente, que os operadores, tanto da LAI quanto da comunicação, que têm conhecimentos mínimos de linguagem, percebem o problema da falta de clareza, e os operadores da LAI que afirmam que os documentos técnicos têm linguagem clara fazem-no sem ter conhecimentos a respeito do assunto. Um operador sugeriu que a solução para essa falta de clareza é que os documentos sejam escritos de forma mais simples. Nessa questão, o operador parece ter razão e vale ressaltar a ideia de que existe a necessidade de uma mudança de paradigma, os servidores públicos precisam escrever para se comunicarem e não apenas para fazer a burocracia estatal funcionar internamente.

Os 13 operadores da LAI entrevistados apontaram que falta conhecimento da população a respeito da lei. Todos os operadores apontaram que existe um uso da lei para atender a interesses individuais e não coletivos. Três operadores disseram acreditar que grande parte dos pedidos de informação vem de servidores públicos. Os 13 operadores afirmaram que parte das informações pedidas, por meio do e-SIC, já estava disponível no site da instituição. Essa situação deixa claro que a grande maioria da população ainda não sabe a respeito da existência da lei e os que sabem ainda têm dificuldades em utilizá-la. Os operadores da LAI queixam-se da falta de divulgação da lei por parte dos próprios Institutos e do governo federal, o que se entende como falta de ações de comunicação, tanto do governo central quanto das suas assessorias na conscientização sobre o direito de acesso às informações públicas. 
Dentre os 19 operadores da comunicação que foram entrevistados, 17 não fizeram nenhum curso de capacitação sobre a Lei de Acesso à Informação. Apenas dois entrevistados foram capazes de relacionar a LAI com a comunicação, fazendo uma análise dessa relação. Parte dos operadores da comunicação apontou, como única mudança trazida pela LAI, o acréscimo de uma sessão no site institucional. Outra parte não conseguiu ver qualquer mudança na comunicação da instituição. Apesar disso, os operadores da comunicação relatam que passaram a encontrar informações com mais facilidade nos sites dos seus institutos, passaram a conhecer melhor sua instituição e ampliaram a consciência quanto às disputas de poder dentro das instituições. Chama a atenção o fato de que, dentre os desconhecedores da LAI, encontram-se os próprios operadores da comunicação dos IF's. Essa falta de conhecimento desses profissionais a respeito da lei e a ausência de relação formal entre os dois setores são alguns dos entraves primordiais e mais importantes a inviabilizar a necessária melhoria no processo de divulgação da lei no âmbito interno das instituições e, em decorrência, no externo, ou seja, na esfera de relacionamento com o público.

Os esforços da Controladoria-Geral da União para implementar a lei obtiveram resultados muito positivos, especialmente considerando o pouco tempo que esse órgão teve para agir e estabelecer as bases legal e operacional que garantiram a implantação da LAI na administração federal. No entanto, apesar do trabalho árduo, ainda falta clareza sobre as ações de transparência ativa nos órgãos em que se realizou esta pesquisa.

Os operadores da comunicação precisam entender que o trabalho realizado pelas assessorias deve ser parte do sistema de transparência do Estado brasileiro e não parte de um sistema de propaganda do Estado, de uma administração ou de um gestor qualquer. Percebi que falta uma cultura de transparência nos setores de comunicação que estão, ainda, muito pautados pelo modelo de comunicação institucional privado com vistas a agir na defensiva contra possíveis ataques da imprensa, das organizações da sociedade, ou mesmo de cidadãos comuns. Segundo Duarte (2009), essas assessorias estão muito voltadas para a divulgação e atendimento dos interesses dos chefes dos órgãos públicos. Esse modelo de comunicação inspirado na iniciativa privada, que visa ao lucro, não me parece adequado às instituições públicas.

A partir da implantação da LAI, a comunicação praticada nos órgãos públicos precisa ser repensada, pautar-se por objetivos mais democráticos e livrar-se dos resquícios de patrimonialismo que ainda são encontrados nas suas práticas. A possível e necessária transfiguração das atuais assessorias em estruturas que divulguem, de forma mais ampla, 
informações de natureza verdadeiramente pública faz surgir questionamentos sobre o possível limite deste trabalho informativo, já que o excesso de transparência poderia ocasionar problemas, em face da existência de distintos temas estratégicos e delicados para governos e instituições. Nesse contexto, para alguns dos entrevistados, "assuntos arriscados" deveriam ser submetidos a um tipo de filtro antes de serem divulgados perante o público.

O desafio será definir com o máximo de clareza e responsabilidade o que será considerado inconveniente, já que quaisquer medidas que se estabeleçam para restringir a divulgação de informações poderão, se mal-utilizadas, beneficiar distintos interesses particulares nos âmbitos políticos ou econômicos. Diante dessas questões, a visão que a LAI oferece por meio de seus princípios considera que é preciso respeitar a autonomia e a capacidade de compreensão, de raciocinar e de decidir dos cidadãos. A comunicação praticada em órgãos públicos não deve tutelar o que os cidadãos podem ou não saber.

O agente político, eleito, ou legitimamente ocupante de cargo público, deve ter a comunicação como um instrumento que lhe dê voz para expor seus pontos de vista perante a população, mas essa mesma estrutura, deve também agir de forma a dar total transparência às coisas do Estado.

A LAI interfere ou deveria interferir em todos os âmbitos da Administração Pública, inclusive nos setores de comunicação dos IF's. Isso porque a lei foi pensada para dar mais transparência ao Estado, promover a democracia e combater a corrupção. Porém, seus princípios ainda são desconhecidos. As normas éticas que a LAI estabelece deveriam ter forte influência na comunicação dos órgãos públicos, pois a lei poderá levar os operadores da comunicação a adquirir novos valores éticos e novas práticas produtivas.

Os suecos, que já têm uma lei de acesso à informação há quase 250 anos, ainda enfrentam problemas e apresentam queixas a respeito da sua legislação (WALLIN, 2014). Portanto, é natural que se encontrem problemas quando se estuda a LAI brasileira. O que essa pesquisa buscou compreender foi, especificamente, o processo de implementação da lei de acesso às informações públicas no Brasil e é sobre isso que coloco meu olhar de forma mais detida nestes últimos parágrafos.

A implementação da legislação aconteceu de maneira apressada, seis meses foi o tempo que ocorreu entre a sanção da lei e a sua entrada em vigor. É um período muito curto para treinar os servidores públicos, especialmente quando se percebe que o treinamento não poderia restringir-se apenas aos funcionários que vão trabalhar operando o e-SIC. Após 
observar os dados obtidos nas entrevistas, fica claro que todos os servidores dos IF's precisam ser capacitados para entender mais que a prática, mas também o espírito da lei.

O processo de implementação está falhando nessa capacitação de servidores. Falha também no planejamento. Houve uma preparação louvável quanto à transparência passiva, mas o que se planejou para a transparência ativa parece um trabalho amador, especialmente quando se compara com a boa experiência que a CGU tem com o Portal da Transparência.

O silenciamento e o secretismo que o sistema burocrático impõe ao serviço público brasileiro precisam ser enfrentados com mais organização, recursos financeiros e disposição política. Organização, pois a transparência ativa carece de coisas mínimas como a definição de quem, afinal, vai controlar a situação, administrar a publicação das informações e verificar sua qualidade. Recursos, pois não é imaginável que milhões de informações guardadas em gavetas tornem-se documentos públicos sem que o Estado tenha custos com isso. E disposição política, pois entende-se que existe a necessidade de se enfrentar uma natural imobilidade do serviço público. É necessário enfrentar essa situação e pressionar mais fortemente a máquina pública para que ela se abra, escreva em termos compreensíveis e permita que a população realmente compreenda como a administração pública funciona. 


\section{Referências}

ACESS INFO disponível em <http://www.access-info.org/>, acessado em 10 de novembro de 2013.

ANGÉLICO, Fabiano. Lei de Acesso à Informação Pública e seus possíveis desdobramentos para a accountability democrática no Brasil. 2012. 133 f. Dissertação (mestrado) - Escola de Administração de Empresas de São Paulo.

ANDI: Agência de Notícias dos Direitos da Infância; Artigo 19. Acesso à Informação e Controle Social das Políticas Públicas, 2009. Disponível em $<$ http://www.cgu.gov.br/acessoainformacao/materiais-interesse/Acesso-a-informacao-e-controlesocial-das-politicas-publicas.pdf $>$, acessado em 20 de outubro de 2013.

ARTIGO 19, disponível em <http://artigo19.org/>, acessado em 23 de março de 2014.

BARDIN, Laurence. Análise de Conteúdo. Lisboa: Edições 70, 1988.

BOBBIO, Norberto. O Futuro da Democracia: Uma Defesa das Regras do Jogo. Rio de Janeiro: Paz e Terra, 1986.

BONFIM, Marcus Vinícius de Jesus. Transparência e accountability na comunicação organizacional do setor público: impactos da Lei de Acesso à Informação. XXXVII Congresso Brasileiro de Ciências da Comunicação, 2014, Foz do Iguaçu. XXXVII Congresso Brasileiro de Ciências da Comunicação. São Paulo, Intercom, 2014.

BRASIL. CONSTITUIÇÃO (1988), Constituição da República Federativa do Brasil: Texto constitucional promulgado em 5 de outubro de 1988, com as alterações adotadas pelas Emendas Constitucionais $n^{\circ} 1 / 92$ a 53/2006 e pelas Emendas Constitucionais de Revisão $n^{\circ} 1$ a 64/94. Brasília: Senado Federal, subsecretaria de Edições Técnicas, 2007.

BRANDÃO, Elizabeth. Conceito de comunicação pública. In: DUARTE, Jorge, Comunicação Pública: Estado, Mercado, Sociedade e Interesse Público. São Paulo: Atlas, 2009. Cap. 7, P. 95-115.

BRESCIANI, E. Sarney defende sigilo eterno de documentos para não 'abrir feridas'. O Estado de São Paulo, junho, 2011. Disponível em <http://blogs.estadao.com.br/radarpolitico/2011/06/13/sarney-defende-sigilo-eterno-de-documentos-para-nao-abrir-feridas/> , acessado em 20 de outubro de 2013.

BUCCI, Eugênio. Em Brasília, 19 horas. Rio de Janeiro: Record, 2008.

Jornalistas e Assessores de Imprensa: profissões diferentes, códigos de ética diferentes. In: A Imprensa e o Dever da Liberdade: a independência editorial e suas fronteiras com a indústria do entretenimento, as fontes, os governos, os corporativismos, o poder econômico e as ONGs. São Paulo: Contexto, 2009a.

Caso Radiobrás: o compromisso com a verdade no jornalismo de uma empresa pública. In: DUARTE, Comunicação Pública: Estado, Mercado, Sociedade e Interesse Público. São Paulo: Atlas, 2009b.

CASTILHO, Alessandra de; MIAN, Mariella Batarra. A Comunicação Pública a caminho da democracia: Análise da implantação da Lei de Acesso à Informação na Universidade Federal do ABC. In: XXXVI Congresso Brasileiro de Ciências da Comunicação, 2013, Manaus. XXXVI Congresso Brasileiro de Ciências da Comunicação. São Paulo, Intercom, 2013.

CGU. 2011, Orientações para a Implementação da Lei de Acesso à Informação nas Ouvidorias Públicas - 
rumo ao sistema participativo. Disponível em <http://www.cgu.gov.br/Publicacoes/ouvidoria/arquivos/oguimplementacao_lai.pdf>. Acessado em 21 de janeiro de 2015.

.2012a, Caderno dos Participantes. $1^{\circ}$ treinamento presencial. Controladoria Geral da União.

. 2012b, Cartilha de Acesso à Informação Pública. Controladoria Geral da União.

CONTROLADORIA-GERAL DA UNIÃO. Orientações para a Implementação da Lei de Acesso à Informação nas Ouvidorias Públicas - rumo ao sistema participativo. Brasília: CGU, 2011.

CUNHA FILHO, Marcio Camargo; XAVIER, Vitor César Silva. Lei de Acesso à Informação, teoria e prática. Rio de Janeiro: Lumen Juris, 2014.

CURTINOVI, Jéfferson; MESQUITA, Wákila. De que comunicação pública estamos falando? In: XXXVI Congresso Brasileiro de Ciências da Comunicação, 2014, Foz do Iguaçu - PR. XXXVI Congresso Brasileiro de Ciências da Comunicação. São Paulo: Intercom, 2014.

Congresso em Foco, Dilma viaja para NY sem lei de acesso na bagagem. Disponível em $<$ http://congressoemfoco.uol.com.br/noticias/manchetes-anteriores/dilma-viaja-para-ny-sem-lei-deacesso-na-bagagem/>, acessado em 20 de outubro de 2013.

Declaração Universal dos Direitos Humanos, disponível em $<$ http://portal.mj.gov.br/sedh/ct/legis intern/ddh_bib_inter_universal.htm>, acessado em 15 de setembro de 2012.

Decreto 7.724 de 16 de maio de 2012. Disponível em <http://www.planalto.gov.br/ccivil_03/_ato20112014/2012/Decreto/D7724.htm>. Acessado em 20 de agosto de 2012.

DINIZ, Maria Helena. Dicionário Jurídico Universitário. São Paulo: Saraiva, 2013.

DUARTE, Jorge. Assessoria de Imprensa no Brasil. In Assessoria de imprensa e relacionamento com a mídia: teoria e técnica. Atlas, 2002.

Entrevista em Profundidade. In: DUARTE, Jorge; Barros, Antonio; (Org.s) Métodos e Técnicas de Pesquisa em Comunicação. São Paulo: Atlas, 2011. Cap. 4, P. $62-83$.

DUARTE, Marcia Yukiko Matsuuchi. Comunicação e Cidadania. In: DUARTE, Comunicação Pública: Estado, Mercado, Sociedade e Interesse Público. São Paulo: Atlas, 2009.

DUTRA, Luma Poletti. Direito à Informação em Pauta: o uso da lei de acesso por jornalistas. 2015. 141 f. Dissertação (mestrado) - Universidade de Brasília, Faculdade de Comunicação.

FLICK, Uwe. Métodos de Pesquisa: Introdução à Pesquisa Qualitativa. Porto Alegre: Artmed, 2009.

FÓRUM DO DIREITO DE ACESSO À INFORMAÇÃO. Disponível em $<$ http://www.informacaopublica.org.br/>. Acessado em 10 de abril de 2014.

FONSECA JÚNIOR, Wilson Corrêa da. Análise de Conteúdo. In: DUARTE, Jorge; Barros, Antonio; (Org.s) Métodos e Técnicas de Pesquisa em Comunicação. São Paulo: Atlas, 2012. Cap. 18, P. 280304.

GERALDES Elen; REIS Lígia. Da Cultura da Opacidade à Cultura da Transparência: apontamentos sobre a Lei de Acesso à Informação Pública. In: XXXV Congresso Brasileiro de Ciências da Comunicação, 2012, Fortaleza. XXXV Congresso Brasileiro de Ciências da Comunicação. 
São Paulo: Intercom, 2012.

GERALDES, Elen; SOUSA, Janara. As Dimensões Comunicacionais da Lei de Acesso à Informação Pública. In: XXXVI Congresso Brasileiro de Ciências da Comunicação, 2013, Manaus. XXXVI Congresso Brasileiro de Ciências da Comunicação. São Paulo: Intercom, 2013.

GENTILLI, Victor; DUTRA, Luma Poletti. Direito à Informação: os jornalistas e o Estado transparente. In: $10^{\circ}$ Encontro Nacional de Pesquisadores em Jornalismo da Associação Brasileira de Pesquisadores em Jornalismo (SBPJor), Curitiba, 2012. Acessado em 5 de junho de 2013. $<$ http://www.sbpjor.org.br/sbpjor/?p=11689>

GIL, Antônio Carlos. Como elaborar Projetos de Pesquisa. São Paulo: Atlas, 2010.

. Métodos e técnicas de pesquisa social. São Paulo: Atlas, 2012.

GOMES, Raimunda Aline Lucena. A comunicação como direito humano: um conceito em construção. 2007. 206 folhas. Dissertação (Mestrado em Comunicação) - Universidade Federal de Pernambuco. Recife, 2007.

HABERMAS, Jurgen. Mudança Estrutural da Esfera Pública, Rio de Janeiro: 1984.

HASWANI, Mariângela Furlan. Comunicação Pública 360 graus e a garantia de direitos. In: KUNSH, Margarida Maria Krohling; (Org.) Comunicação Pública, Sociedade e Cidadania. São Caetano do Sul, SP: Difusão Editora, 2011.

INFORMAÇÃO PÚBLICA. Fórum de Direito de Acesso a Informações Públicas. Disponível em $<$ http://www.informacaopublica.org.br/>, acessado em 20 de novembro de 2011.

JARDIM, José Maria. Transparência e opacidade do estado no Brasil: usos e desusos da informação governamental. Niterói : EdUFF, 1999.

JÚNIOR, Wilson Corrêa da Fonseca. Análise de Conteúdo. In: DUARTE, Jorge; Barros, Antonio; (Org.s) Métodos e Técnicas de Pesquisa em Comunicação. São Paulo: Atlas, 2011. Cap. 18, P. 280 304.

Lei 12.528 de 18 de novembro de 2011. Disponível em $<$ http://www.planalto.gov.br/ccivil 03/_Ato2011-2014/2011/Lei/L12528.htm>, acessado em 10 de agosto de 2013.

Lei 1.527 de 18 de novembro de 2011, disponível em <http://www.planalto.gov.br/ccivil_03/_ato20112014/2011/lei/112527.htm>, acessado em 15 de setembro de 2012.

MALTECHIK, R. Collor e Sarney 'seguram' votação de projeto sobre Lei de Acesso à Informação Pública. O Globo, junho, 2011. Disponível em <http://oglobo.globo.com/politica/collorsarney-seguram-votacao-de-projeto-sobre-lei-de-acesso-informacao-publica-2755994>, acessado em 20 de outubro de 2013.

MARSHAL, T. H. Cidadania, Classe Social e Status. Rio de Janeiro: Zahar, 1967.

MELO, Alice. Rumo à Abertura. Revista de história. Disponível em $<$ http://www.revistadehistoria.com.br/secao/reportagem/rumo-a-abertura $>$, acessado em $1^{\text {o }}$ de dezembro de 2013.

MENDEL, Toby. Liberdade de Informação: um estudo de direito comparado, Unesco, 2009, 
disponível

em:

$<$ http://portal.unesco.org/ci/en/files/26159/126398551119freedom_information_pt.pdf/freedom_infor

mation_pt.pdf $>$ baixado em 25 de maio de 2011.

MESQUITA, Wákila N. R. de. (2014a). Políticas de Acesso à Informação: a transparência ativa nos sites dos Institutos Federais de Educação, Ciência e Tecnologia. In: XVI Congresso Brasileiro de Ciências da Comunicação na Região Centro-Oeste, 2014, Águas Claras, Brasília. XVI Congresso Brasileiro de Ciências da Comunicação na Região Centro-Oeste. São Paulo, Intercom, 2014.

(2014b). Lei de Acesso à Informação: a transparência ativa nos sites dos Institutos Federais de Educação, Ciência e Tecnologia. In: XXXVII Congresso Brasileiro de Ciências da Comunicação, 2014, Foz do Iguaçu. XXXVII Congresso Brasileiro de Ciências da Comunicação. São Paulo, Intercom, 2014.

MOREIRA, Hércules Silva; CASSIANO, Sandra; SCHMIDT, Cristina. A implantação da Lei de Acesso à Informação nos Estados brasileiros. In: XXXVII Congresso Brasileiro de Ciências da Comunicação, 2014, Foz do Iguaçu. XXXVII Congresso Brasileiro de Ciências da Comunicação. São Paulo, Intercom, 2014.

PAULINO, Fernando de Oliveira; SILVA, Luiz Martins. Jornalismo, transparência e aplicação da Lei de Acesso à Informação nas Universidades Federais. In: $10^{\circ}$ Encontro Nacional de Pesquisadores em Jornalismo da Associação Brasileira de Pesquisadores em Jornalismo (SBPJor), Curitiba, 2012. Acessado em 5 de junho de 2013. <http://www.sbpjor.org.br/sbpjor/?p=11689>

PORTAL

MEC

$<$ http://portal.mec.gov.br/index.php?option=com_content\&view=article\&id=17725> $>$, acessado em 28 de outubro de 2014.

RABAÇA, Carlos Alberto; BARBOSA, Gustavo. Dicionário de Comunicação. Rio de Janeiro: Campus Elsevier, 2002.

REIS, Lígia Maria de Sousa Lopes. A lei brasileira de acesso à informação e a construção da cultura da transparência no Brasil: os desafios para a implementação da norma e o agir comunicativo no enfrentamento da opacidade estatal. 2014. 150 f. Dissertação (mestrado) Universidade de Brasília, Faculdade de Comunicação.

ROSA, Elisa Costa Ferreira; MAINIERI, Tiago. Reflexões sobre a Lei de Acesso à Informação no Brasil: o papel das relações-públicas para o diálogo entre cidadão e Estado. In: XXXV Congresso Brasileiro de

Ciências da Comunicação, 2012, Fortaleza. XXXV Congresso Brasileiro de Ciências da Comunicação. São Paulo: Intercom, 2012.

ROSSO, Gisele. Processos Comunicativos na Perspectiva da Comunicação Pública: o caso do Ministério Público do Trabalho no Paraná. 2012. 150 f. Dissertação (mestrado) - Universidade Federal do Paraná.

SOUZA, Rose Mara Vida. A Nova Lei de Acesso à Informação e os impactos nas práticas jornalísticas. Trabalho apresentado no $11^{\circ}$ Encontro Nacional de Pesquisadores em Jornalismo da Associação Brasileira de Pesquisadores em Jornalismo (SBPJor), Brasília, 2013.

VOGEL, Maico. Os valores-notícia na produção de conteúdo jornalístico originado da Lei de Acesso à Informação. In: XIV Congresso Brasileiro de Ciências da Comunicação na Região Sul, 2013, Santa Cruz do Sul. XIV Congresso Brasileiro de Ciências da Comunicação na Região Sul. São Paulo, Intercom, 2013. 
ZÉMOR, Pierre. As Formas da Comunicação Pública. In: DUARTE, Comunicação Pública: Estado, Mercado, Sociedade e Interesse Público. São Paulo: Atlas, 2009. Cap. 15, P. 214-243.

WEBER, Maria Helena. Estratégias da comunicação de Estado e a disputa por visibilidade. In: KUNSH, Margarida Maria Krohling; (Org.) Comunicação Pública, Sociedade e Cidadania. São Caetano do Sul, SP: Difusão Editora, 2011.

WALLIN, Claudia. Um país sem excelências e mordomias. São Paulo: Geração Editorial, 2014.

WOLTON, Dominique. Pensar a comunicação. Brasília: UnB, 2004.

É preciso salvar a comunicação. São Paulo: Paulus, 2006. 